U.S. Department of the Interior

U.S. Geological Survey

Prepared in cooperation with IDAHO TRANSPORTATION DEPARTMENT

IDAHO BUREAU OF DISASTER SERVICES

U.S. ARMY CORPS OF ENGINEERS

\title{
Estimating the Magnitude of Peak Flows at Selected Recurrence Intervals for Streams in Idaho
}

Water-Resources Investigations Report 02-4170 


\section{Estimating the Magnitude of Peak Flows at Selected Recurrence Intervals for Streams in Idaho}

ByCharles Berenbrock

Water-Resources Investigations Report 02-4170

Prepared in cooperation with

IDAHO TRANSPORTATION DEPARTMENT

IDAHO BUREAU OF DISASTER SERVICES

U.S. ARMY CORPS OF ENGINEERS

Boise, Idaho

2002 
U.S. DEPARTMENT OF THE INTERIOR

Gale A. Norton, Secretary

U.S. GEOLOGICAL SURVEY

Charles G. Groat, Director

The use of firm, trade, and brand names in this report is for identification purposes only and does not constitute endorsement by the U.S. Government.

Additional information can be obtained from:

District Chief

U.S. Geological Survey

230 Collins Road

Boise, ID 83702-4520

http://idaho.usgs.gov
Copies of this report can be purchased from:

U.S. Geological Survey

Information Services

Box 25286

Federal Center

Denver, CO 80225

e-mail: infoservices@usgs.gov
Copies of this report also are available in PDF format, which can be viewed using Adobe Acrobat Reader, at URL: http://idaho.usgs.gov/public/reports.html 


\section{CONTENTS}

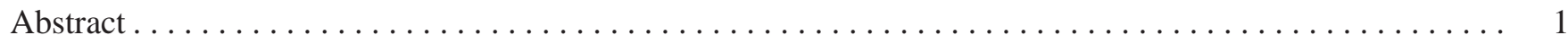

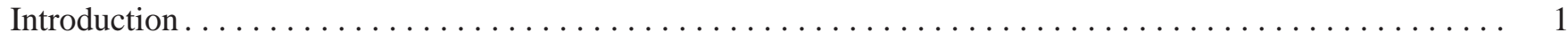

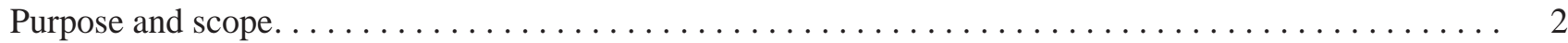

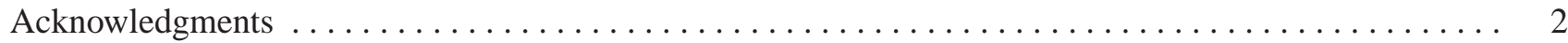

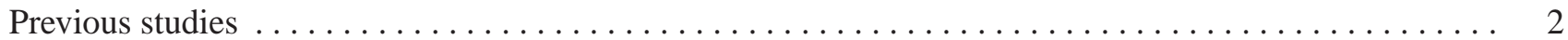

General description of study area $\ldots \ldots \ldots \ldots \ldots \ldots \ldots$

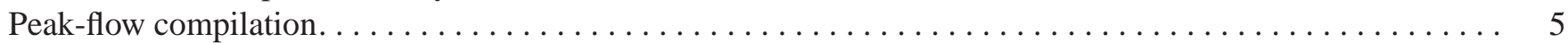

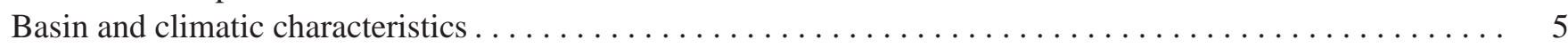

Determination of regions for regional regression analysis $\ldots \ldots \ldots \ldots \ldots$

Methods for estimating peak flows for gaged sites $\ldots \ldots \ldots \ldots \ldots$

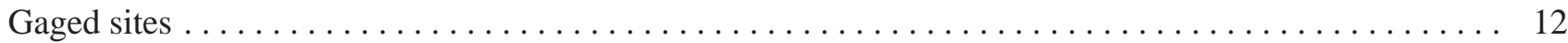

Ungaged sites near gaged sites on the same stream $\ldots \ldots \ldots \ldots \ldots$

Methods for estimating peak flows for ungaged sites $\ldots \ldots \ldots \ldots \ldots$

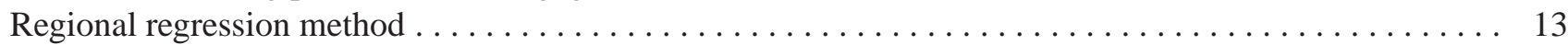

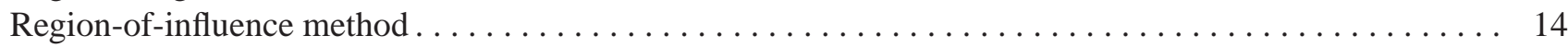

Results of estimating peak flows for ungaged sites $\ldots \ldots \ldots \ldots \ldots \ldots$

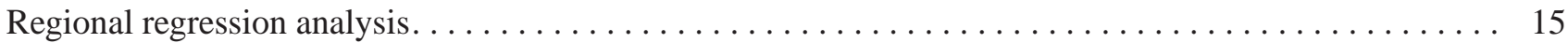

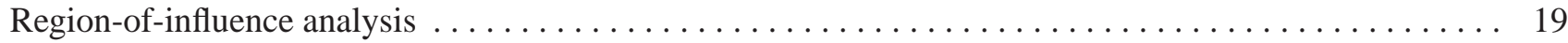

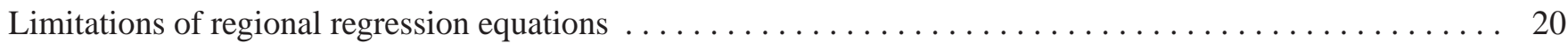

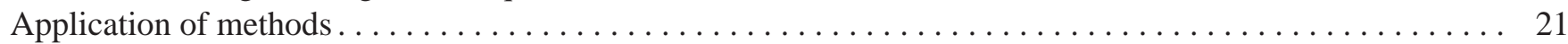

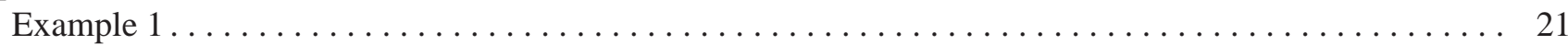

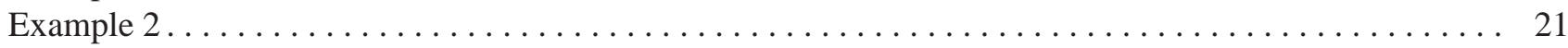

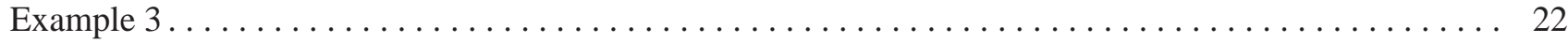

Computer program for regional regression equations $\ldots \ldots \ldots \ldots \ldots \ldots \ldots$

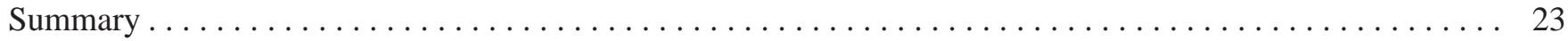

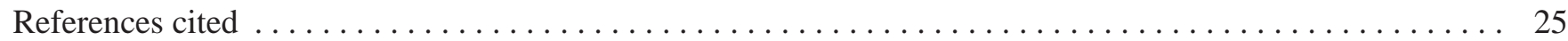

\section{FIGURES}

1. Locations of streamflow-gaging stations in Idaho and bordering States used in regional

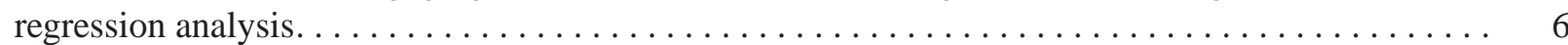

2. Graph showing comparison between GIS-calculated drainage area and national WATSTORE drainage area for streamflow-gaging stations in Idaho and bordering States . . . . . . . . . . . . . . . . . . .

3. Map showing locations of regions in Idaho used in regional regression analysis. . . . . . . . . . . 11

4. Graph showing the joint distribution of drainage area and mean basin elevation, and minimum covering ellipsoid for gaged sites in region 3 , Idaho $\ldots \ldots \ldots \ldots \ldots$

5. Input session of example 2 for the regional regression program (idregeq.exe) $\ldots \ldots \ldots \ldots$

\section{TABLES}

1. Average standard errors of prediction for selected peak-flow recurrence intervals estimated by using regional regression equations from previous studies in Idaho $\ldots \ldots \ldots \ldots \ldots \ldots \ldots \ldots$

2. Selected data sources used to obtain basin and climatic characteristics for regional regression

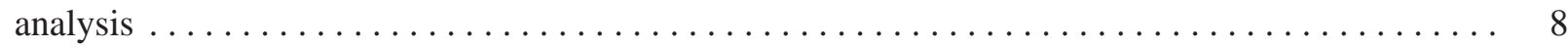

3. Description of selected basin and climatic characteristics used in the final predictive equations ... . 9 
4. Basin and climatic characteristics for streamflow-gaging stations in Idaho and bordering States used in regional regression analysis . . . . . . . . . . . . . . . . . . . . . . . . . . 29

5. Peak flows at selected recurrence intervals for streamflow-gaging stations in Idaho and bordering

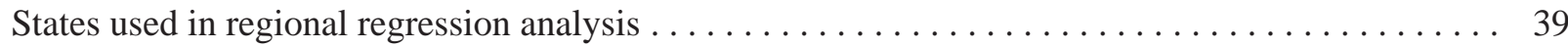

6. Value of exponent, a, for regions in Idaho used in regional regression analysis . . . . . . . . 13

7. Predictive regression equations and their accuracy in estimating peak flows for ungaged sites on

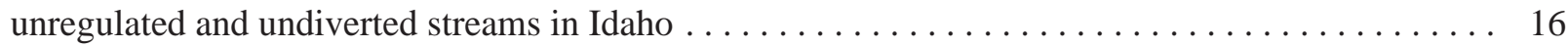

8. Average root-mean-squared errors, in percent, for region-of-influence and regional regression methods for selected recurrence intervals $\ldots \ldots \ldots \ldots \ldots \ldots \ldots \ldots \ldots \ldots \ldots \ldots \ldots$

9. $\left(\mathrm{X}^{\mathrm{T}} \Lambda^{-1} \mathrm{X}\right)^{-1}$ matrices for the $\mathrm{T}$-year $(\mathrm{T}=2,5,10,25,50,100,200$, and 500) regional

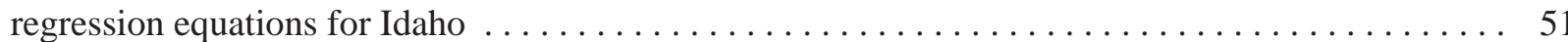

\section{CONVERSION FACTORS, VERTICAL DATUM, AND WATER YEAR DEFINITION}

\begin{tabular}{rll}
\hline Multiply & \multicolumn{1}{c}{ By } & To obtain \\
\hline cubic foot per second $\left(\mathrm{ft}^{3} / \mathrm{s}\right)$ & 0.02832 & cubic meter per second \\
foot $(\mathrm{ft})$ & 0.3048 & meter \\
foot per mile $(\mathrm{ft} / \mathrm{mi})$ & 0.1894 & meter per kilometer \\
inch (in.) & 2.54 & centimeter \\
mile (mi) & 1.609 & kilometer \\
square mile $\left(\mathrm{mi}^{2}\right)$ & 2.590 & square kilometer \\
\hline
\end{tabular}

Sea level: In this report, "sea level" refers to the North American Vertical Datum of 1988 (NAVD of 1988)—a vertical control datum established by the minimum-constraint adjustment of Canadian-Mexican-United States leveling observations and held fixed at Father Point/Rimouski, Quebec, Canada.

Water year: In U.S. Geological Survey reports dealing with surface-water supply, a water year is the 12-month period, October 1 through September 30. The water year is designated by the calendar year in which it ends; thus, the water year ending September 30, 2002, is called the "2002 water year." 


\section{ERRATA}

Table 4 of this report contains a typographical error. On page 30, in the row for Map No. 56, Selway River near Lowell, ID, the value for $\mathrm{S} 30$ (percent) is listed as 785.6. The correct value is 75.6.

[Updated July 25, 2007] 
This page intentionally left blank 


\title{
Estimating the Magnitude of Peak Flows at Selected Recurrence Intervals for Streams in Idaho
}

\author{
By Charles Berenbrock
}

\section{Abstract}

Methods for estimating magnitudes of peak flows at various recurrence intervals, needed for highway-structure and water-control design and planning, were developed for gaged and ungaged sites on streams throughout Idaho. Recurrence intervals of 2, 5, 10, 25, 50, 100, 200, and 500 years were selected for analysis of peak flows.

For gaged sites in Idaho, peak-flow estimates were calculated by fitting a log-Pearson Type III distribution to the annual peak-flow data for each site. Annual peak flows through 1997 were used in the analysis. Basin and climatic characteristics for these gaged sites were calculated from 1:24,000 digitalelevation models and various thematic data coverages using a geographic information system. Peakflow data and basin and climatic characteristics for 333 gaged sites were combined to develop a database that was used for the analysis. To estimate the magnitude of peak flows at ungaged sites near gaged sites on the same stream, a method was developed on the basis of drainage-area ratios.

To estimate the magnitude of peak flows for ungaged sites on unregulated and undiverted streams, two regional regression methods were developed. The first regression method, termed the regional regression method, used generalized least-squares regression to develop a set of predictive equations for estimating peak flows at selected recurrence intervals for seven hydrologic regions in Idaho. These regional regression equations related basin and climatic characteristics to peak flows. The regional regression equations were all functions of drainage area plus one or two other basin characteristics. Average errors of prediction for these regression equations ranged from +143 percent to -58.8 percent. The range of errors was narrowest, from about +51.9 to about -34.2 , for region 5. Error ranges were usually narrower for the middle recurrence intervals than for the lower and upper recur- rence intervals. A computer program was developed to calculate the magnitude of peak flows at each recurrence interval, the average error of prediction, and the 90-percent confidence interval for each ungaged site.

The second regression method, termed the region-of-influence method, was used to develop a unique regression equation for each estimate that is based on a subset of gaged sites with values of basin and climatic characteristics similar to those for the ungaged sites. All 333 gages in the database were used to select the subset. Root-mean-squared errors for this method ranged from 55.5 percent to 72.4 percent. Differences in root-mean-squared errors between regional regression equations and the region-of-influence method were quite large. The average difference in root-mean-squared errors for the region-of-influence method was more than 10 percent greater than the average differences for the regional regression equations. For region 5, the average difference was greater than 20 percent. However, for region 8 , the root-mean-squared errors were, in general, only slightly smaller for the region-of-influence method than for the regional regression equations. The region-of-influence method is not recommended for use in determining flood-frequency estimates for ungaged sites in Idaho because the results, overall, are less accurate and the calculations are more complex than those of regional regression equations. The regional regression equations were considered to be the primary method of estimating the magnitude and frequency of peak flows for ungaged sites in Idaho.

\section{INTRODUCTION}

Reliable estimates of the magnitude and frequency of floods (termed peak flows in this report) are needed by Federal, State, regional, and local designers and managers. The design of highway, road, and railroad stream crossings; delineation of flood plains and flood- 
prone areas; management of water-control structures; and management of irrigation and water supplies are all activities that require estimates of the frequency distributions, or recurrence intervals, of peak flows. Such estimates can be calculated directly by using statistical methods for gaged sites (sites where streamflow-gaging stations, or gages, have been established) that have at least 10 years of annual peak-flow record (Riggs, 1972; Interagency Advisory Committee on Water Data, 1982). Longer records usually result in more reliable estimates. It is not feasible, however, to collect 10 years of annual peak-flow records for every location where an estimate of the flood-frequency distribution is needed, nor is it reasonable to wait 10 years for an estimate once a site has been identified.

Accurate estimates of peak-flow magnitudes at various frequencies are necessary for effective structural design and planning purposes. Underestimating peak flows can result in loss of life, disruption of service, and costly maintenance, and overestimates can result in excessive construction cost. Unfortunately, design and planning activities often require peak-flow magnitude and frequency information for locations where there are inadequate or no peak-flow data. To meet information needs for design and planning, estimates of the magnitude of annual peak flows for gaged sites have been regionalized. This process relates flood frequencies estimated for gaged sites to measurable basin and climatic or channel-geometry characteristics so that reliable flood frequencies can be estimated for ungaged sites by use of regression equations. Floodfrequency studies have been conducted within Idaho since the 1970s (see "Previous Studies" section). Often, the area of study was subdivided into regions of similar hydrology (hydrologic regions) to improve the predictive ability of the regression equations.

In 1998, the U.S. Geological Survey (USGS) conducted a study in cooperation with the Idaho Transportation Department (ITD), Idaho Bureau of Disaster Services (BDS), and U.S. Army Corps of Engineers (COE) to develop regional regression equations that would define the relation between peak flows and basin characteristics. The equations and the estimating methods used in this study will provide more accurate estimates of peak flows for Idaho than provided in previous reports because of the use of additional data and availability of more robust statistical methods.

\section{Purpose and Scope}

This report documents estimation of the magnitude of peak flows at recurrence intervals of 2, 5, 10, $25,50,100,200$, and 500 years. Two methods, the logPearson Type III distribution and the drainage-area ratio, are presented for estimating peak flows for gaged sites and for ungaged sites near gaged sites on the same stream. Two methods based on regression analysis are presented for estimating peak flows for ungaged sites on unregulated and undiverted streams in Idaho- the regional regression method and the region-of-influence method. Standard errors of estimate were calculated to show the predictive reliability of each method, and the results were compared to evaluate their applications and limitations. To compare the two methods on an equal basis, each method was applied to the same dataset, which consisted of 333 gaged sites with at least 10 years of unregulated, undiverted peak-flow record. Information in this report describing peak-flow compilation and methods for estimating peak flows for ungaged sites was derived mainly from documentation of a similar study in North Carolina by Pope and Tasker (1999).

For information on estimating peak flows in urbanized drainage basins, the reader is referred to a national study by Sauer and others (1983). Techniques for estimating peak flows for ungaged sites on regulated streams were beyond the scope of this report.

\section{Acknowledgments}

The author recognizes the hard work and dedication of the many USGS hydrologic technicians in collecting, processing, and storing the peak-flow data necessary for the completion of this report. Also, the author appreciates the assistance of the many Federal, State, and local agencies that financially supported operation of gages throughout Idaho where peak-flow data are collected. Special recognition goes to Gary Tasker, USGS, who provided a computer program for use in this study.

\section{Previous Studies}

Thomas and others (1973) were the first to develop regional regression equations for estimating flood-frequency characteristics for Idaho streams. Their regression equations only directly determined the 10-year peak flow $\left(\mathrm{Q}_{10}\right)$. Ratios were used to estimate the 25- 
year $\left(\mathrm{Q}_{25}\right)$ and 50-year peak flows $\left(\mathrm{Q}_{50}\right)$. Standard errors for $\mathrm{Q}_{10}$ ranged from 41 to 62 percent (table 1). Their equations were applicable only for streams draining areas between 0.5 and $200 \mathrm{mi}^{2}$. In their analysis, the State was divided into nine regions and separate regression equations and ratios were developed for each. The following basin characteristics were used in one or more of their equations: basin area, percent forest area, percent water area, and latitude and longitude. Harenberg (1980) developed several sets of regression equations for Idaho on the basis of channel-geometry and basin characteristics. The characteristics used in his study were bankfull width, drainage area, and the 24-hour rainfall intensity for the 2-year recurrence interval. He used fewer than half of the gaging stations used in the previous study because channel-geometry characteristics could not be determined at every gage. He demonstrated that standard errors were smaller when channel-geometry variables were included with basin characteristics in regression equations, but standard errors in his study were 20 to 30 percent larger than in the previous study (table 1), which used a dataset twice as large.

Using peak-flow data through 1977, Kjelstrom and Moffatt (1981) developed regional regression equations using the method of moments. About 270 gages were used and the State was divided into three regions. Their equations used one or more of the following basin characteristics to calculate the logarithmic mean and logarithmic standard deviation: drainage area, mean basin elevation, percent forest cover, slope of the main channel, mean annual precipitation in the basin, mean minimum January temperature of the basin, and the 24-hour rainfall intensity for a 2-year recurrence interval. The frequency factor for the selected recurrence interval then was multiplied by the logarithmic standard deviation and added to the logarithmic mean to obtain the logarithmic magnitude of peak flow.

Table 1. Average standard errors of prediction for selected peak-flow recurrence intervals estimated by using regional regression equations from previous studies in Idaho

$\left[Q_{10}\right.$, peak flow with a recurrence interval of 10 years; $Q_{25}$, peak flow with a recurrence interval of 25 years; $Q_{50}$, peak flow with a recurrence interval of 50 years; $Q_{100}$, peak flow with a recurrence interval of 100 years; min, minimum value; max, maximum value; -, no regional regression equations were available for the indicated recurrence interval]

\begin{tabular}{|c|c|c|c|c|c|c|c|c|}
\hline \multirow{2}{*}{\multicolumn{2}{|c|}{ Peak flow }} & \multicolumn{7}{|c|}{ Average standard errors of prediction, in percent } \\
\hline & & \multirow{2}{*}{\begin{tabular}{|c|}
$\begin{array}{c}\text { Thomas } \\
\text { and } \\
\text { others } \\
\text { (1973) }\end{array}$ \\
41 \\
\end{tabular}} & \multirow{2}{*}{$\begin{array}{c}\begin{array}{c}\text { Harenberg } \\
\text { (1980) }\end{array} \\
71\end{array}$} & \multirow{2}{*}{$\begin{array}{c}\begin{array}{c}\text { Kjelstrom } \\
\text { and } \\
\text { Moffatt } \\
\text { (1981) }\end{array} \\
{ }^{1} 41\end{array}$} & \multirow{2}{*}{$\begin{array}{c}\begin{array}{c}\text { Quillian } \\
\text { and } \\
\text { Harenberg } \\
\text { (1982) }\end{array} \\
49\end{array}$} & \multirow{3}{*}{$\begin{array}{c}\begin{array}{c}\text { Hedman } \\
\text { and } \\
\text { Osterkamp } \\
(1982)\end{array} \\
{ }^{2} 60\end{array}$} & \multirow{2}{*}{ 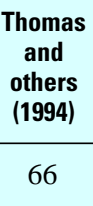 } & \multirow{2}{*}{$\begin{array}{c}\begin{array}{c}\text { This } \\
\text { study }\end{array} \\
41\end{array}$} \\
\hline \multirow{2}{*}{$\mathrm{Q}_{10}$} & $\min$ & & & & & & & \\
\hline & $\max$ & 62 & 92 & ${ }^{1} 90$ & 107 & & 95 & 77 \\
\hline \multirow{2}{*}{$\mathrm{Q}_{25}$} & $\min$ & - & 71 & ${ }^{1} 41$ & - & \multirow{2}{*}{${ }^{2} 62$} & 66 & 40 \\
\hline & $\max$ & - & 92 & ${ }^{1} 90$ & - & & 90 & 75 \\
\hline \multirow{2}{*}{$\mathrm{Q}_{50}$} & $\min$ & - & 71 & ${ }^{1} 41$ & 46 & \multirow{2}{*}{${ }^{2} 71$} & 72 & 41 \\
\hline & $\max$ & - & 91 & ${ }^{1} 90$ & 118 & & 89 & 72 \\
\hline \multirow{2}{*}{$\mathrm{Q}_{100}$} & $\min$ & - & 72 & ${ }^{1} 41$ & 49 & \multirow{2}{*}{${ }^{2} 83$} & 77 & 41 \\
\hline & $\max$ & - & 91 & ${ }^{1} 90$ & 123 & & 90 & 72 \\
\hline
\end{tabular}


The antilogarithm then was applied to obtain the magnitude of peak flow. Standard errors of estimate in their study ranged from 41 to 90 percent (table 1).

In a network and cost-estimate analysis of gages in Idaho, Quillian and Harenberg (1982) developed regional regression equations for nine regions in the State. They used the same regions as in the first regional regression study by Thomas and others (1973). They developed equations for the 2-, 10-, 50-, and 100-year peak flows and the mean annual flow. Their equations were based on basin characteristics, and standard errors were larger than errors from the three previous regional regression studies. Hedman and Osterkamp (1982) also developed regional regression equations for selected peak flows and for the mean annual flow for the western half of the United States. Their equations were based on channel-geometry characteristics, and drainage basins in the State were grouped into a much larger region composed of the Rocky Mountains. However, data from only three gages in Idaho were used in their analysis. These gages were located on tributaries to the Snake River. Standard errors were within the ranges of error from the previous studies (table 1).

Thomas and others (1994) developed regional regression equations for 16 regions in the southwestern United States. Only the southern part of Idaho was included in their analysis, which comprised four regions. The eastern and western Snake River Plain regions composed most of the area. Basin and climatic characteristics (basin area, mean elevation, and (or) mean annual precipitation) also were needed to determine the peak flow at the selected recurrence interval. They used peak-flow data through 1991. Standard errors for their study were similar to those from previous studies that used basin and climatic characteristics (table 1).

\section{General Description of Study Area}

The landscape of Idaho is quite diverse, with areas of flat, extensive plains, rolling hills, and rugged mountains. Land-surface elevations range from 14,000 ft above sea level at Borah Peak to about 1,800 ft at Porthill, in the northern part of the State. A prominent geographic feature of Idaho is the Snake River Plain, which bisects the southern part of the State. Volcanic rocks and alluvium underlie the plain and, in the eastern part, much of the volcanic rock is exposed. In the western part of the plain, however, the alluvium is thousands of feet thick. Land use in the plain is mostly desert shrubs and large tracts of irrigated lands. Most of the State north of the Snake River Plain is in the Rocky Mountains and is underlain principally by granitic rocks. Land use in this area is dominated by forest and woodland, except in the area between Coeur d'Alene Lake and the Clearwater River, where cropland is the major land use.

Annual precipitation varies widely in the State, primarily because of orographic effects. Annual precipitation tends to be greatest in the mountains, where it is as much as $70 \mathrm{in}$. in the northern and central mountains that border Montana (Molnau, 1995). Valley areas tend to be drier than adjacent mountains, especially in Birch Creek and Big Lost, Little Lost, Pahsimeroi, and Lemhi River Valleys. In the Snake River Plain, annual precipitation is less than $10 \mathrm{in.}$

Annual runoff generally follows the precipitation pattern, and quantities are larger in areas of higher elevation. Streamflows vary greatly on a seasonal basis, as snowmelt provides the bulk of annual runoff in May, June, and July for mountain streams and in March, April, and May for streams draining the lower foothills and valley-floor areas. Streamflows generally are smallest in late fall and winter, and many streams can become dry during this period.

The major drainage basins in Idaho are the Snake, Salmon, Clearwater, Spokane, Pend Oreille, and Kootenai River Basins, which are all within the Columbia River Basin. The Snake River drains most of the southern half of the State (fig. 1). Near King Hill, more than $5,000 \mathrm{ft}^{3} / \mathrm{s}$ discharges to the Snake River from ground water (Kjelstrom, 1995). The Snake River winds westward through the Snake River Plain until it reaches Oregon, then heads northward to the city of Lewiston, Idaho (fig. 1). In central Idaho, the Salmon River joins the Snake River at the Idaho-Oregon boundary about $40 \mathrm{mi}$ south of Lewiston, and the Clearwater River joins the Snake River at Lewiston. In northern Idaho, the Coeur d'Alene River flows westward to Coeur d'Alene Lake. The lake's outlet drains to the Spokane River, which flows westward from Idaho to Washington and joins the Columbia River. The Clark Fork flows from Montana into Idaho and into Pend Oreille Lake. The lake's outlet drains to the Pend Oreille River, which winds westward through Idaho to Washington and joins the Columbia River. The Kootenai River flows northwestward from Montana through a small area of Idaho to Canada and joins the Columbia River. 


\section{PEAK-FLOW COMPILATION}

The first step in the regionalization of flood-frequency estimates is compilation of a list of all gaged sites with annual peak-flow records. Such sites are either continuous-record sites or crest-stage sites. At continuous-record sites, the water-surface elevation, or stage, of the stream is recorded at fixed intervals, typically ranging from 5 to 60 minutes. At crest-stage sites, only the crest, or highest stages that occur between site visits (usually several months) are recorded. Regardless of the type of gage, discharge measurements are made throughout the range of recorded stages, and a relation between stage and discharge is developed for the gaged site. Using this stage-discharge relation, or rating, discharges for all recorded stages are determined. The highest peak discharge that occurs during a given year is the annual peak for the year, and the list of annual peaks is the annual peak-flow record.

Initially, more than 500 gages, including gages from bordering States, were determined to have some annual peak-flow records. Examination of flow records for these gages revealed that many were on streams regulated by reservoirs or had irrigation diversion(s) that would significantly affect peak flows at the gage. These gages then were excluded from the database. Gages that did not have 10 or more years of peak-flow records were excluded from the database and not used in any subsequent calculations (Riggs, 1972; Interagency Advisory Committee on Water Data, 1982). Flood-frequency characteristics for the remaining 333 gages (fig. 1) were calculated and formed the database that was used for the regional regression and regionof-influence methods.

\section{BASIN AND CLIMATIC CHARACTERISTICS}

Because basin and climatic characteristics are widely used in regression equations, several basin and climatic variables have been measured previously at most USGS gages in Idaho and bordering States. These data were stored in the Basin Characteristics File of the USGS Water Data Storage and Retrieval System (WATSTORE) and were determined by measuring the characteristic on the largest scaled (most detailed) topographic map available. For example, drainage area was determined by manually planimetering the outline of the basin upstream from each gage and was usually done on 1:24,000-scale maps (USGS 7.5-minute quad- rangle maps) to ensure consistency of the data. Other basin and climatic characteristics that were measured at some gages and stored in WATSTORE included basin perimeter, mean basin elevation, basin slope, basin relief, drainage density, and aspect.

Except for drainage area, basin and climatic characteristic data were not readily available for all gages used in this study. In addition, mean annual precipitation for each basin had to be reevaluated because more recent estimates throughout Idaho were available (Molnau, 1995). Because of the large number of sites involved and the need for consistent and unbiased methodology in making measurements and calculations, the Arc/Info geographic information system (GIS) was used to measure and calculate basin and climatic characteristics.

Therefore, all basin characteristics in this study, including the remeasurement of drainage area, were obtained using Arc Macro Language programs written for Arc/Info (Environmental Systems Research Institute, Inc., 1999). These programs generated the basin characteristic values from the datasets listed in table 2 . More than 50 separate basin and climatic characteristics were obtained for each of the 333 gages included in the study. Several characteristics were removed from consideration after correlation plots of the data were reviewed. Generally, if two basin characteristics correlated well, the one that was the least difficult to obtain was kept and the other was removed from the database. Other characteristics were removed because of missing data or difficulty in obtaining data. By following this process, 18 basin and climatic characteristics were retained for use in the multiple-regression analysis. Of the 18 characteristics used in the analysis, 7 were included in at least one of the final equations. These 7 standard characteristics were: drainage area (DA), mean basin elevation (E), forested area $(F)$, mean annual precipitation (P), basin slope (BS), north-facing slopes greater than 30 percent (NF30), and slopes greater than 30 percent (S30). Basin azimuth, area higher than $6,000 \mathrm{ft}$ in elevation, slope of the main channel, length of the main channel, basin relief, basin perimeter, ruggedness number (basin relief divided by square root of drainage area), area of basin containing sedimentary rocks, area of basin containing granitic rocks, area of basin containing volcanic rocks, and minimum average temperatures also were included in the analysis but were not used in any of the equations. General descriptions of how the 7 basin and climatic characteristics used in the equations were measured are listed in table 

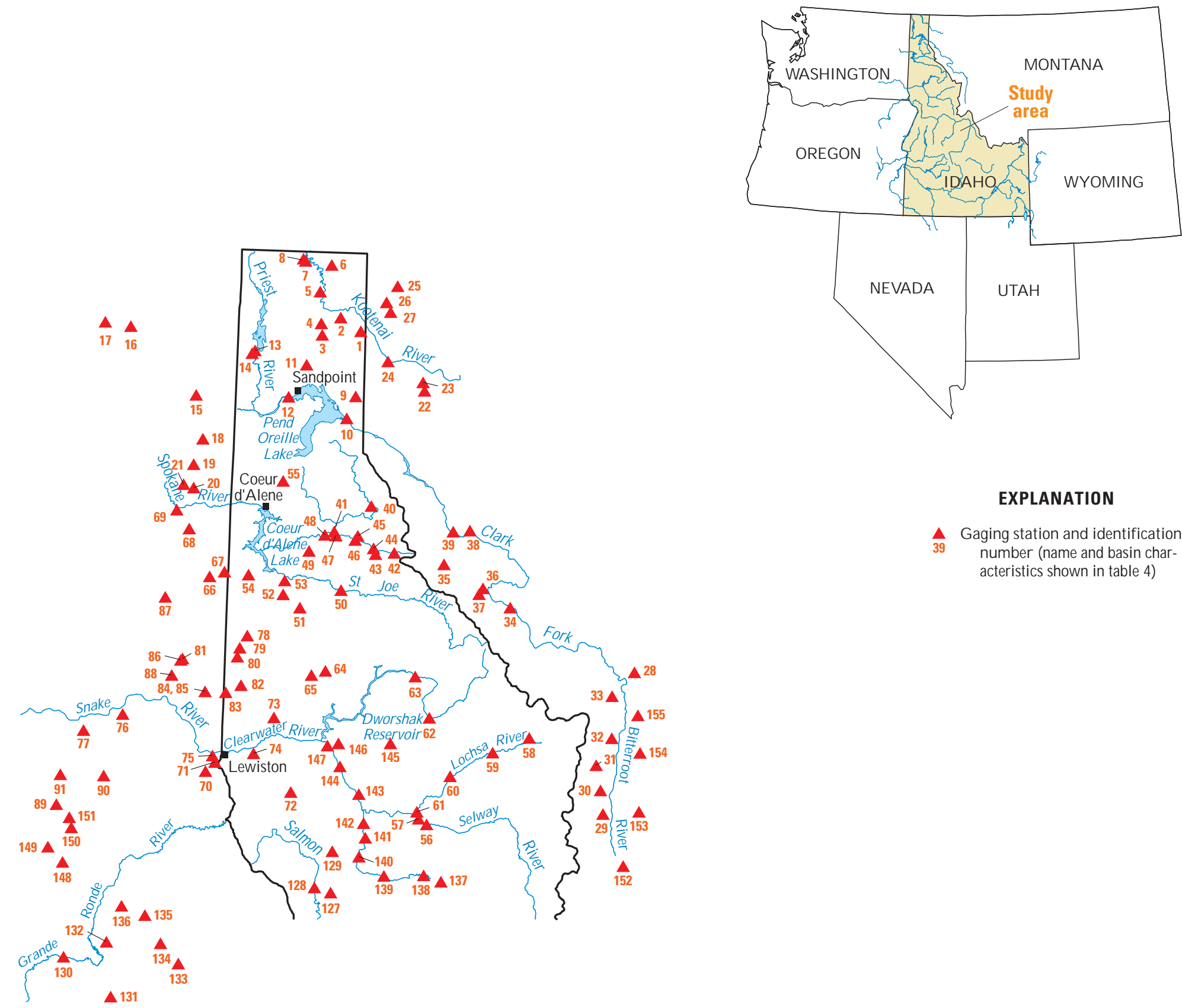

\section{EXPLANATION}

Gaging station and identification number (name and basin characteristics shown in table 4) 


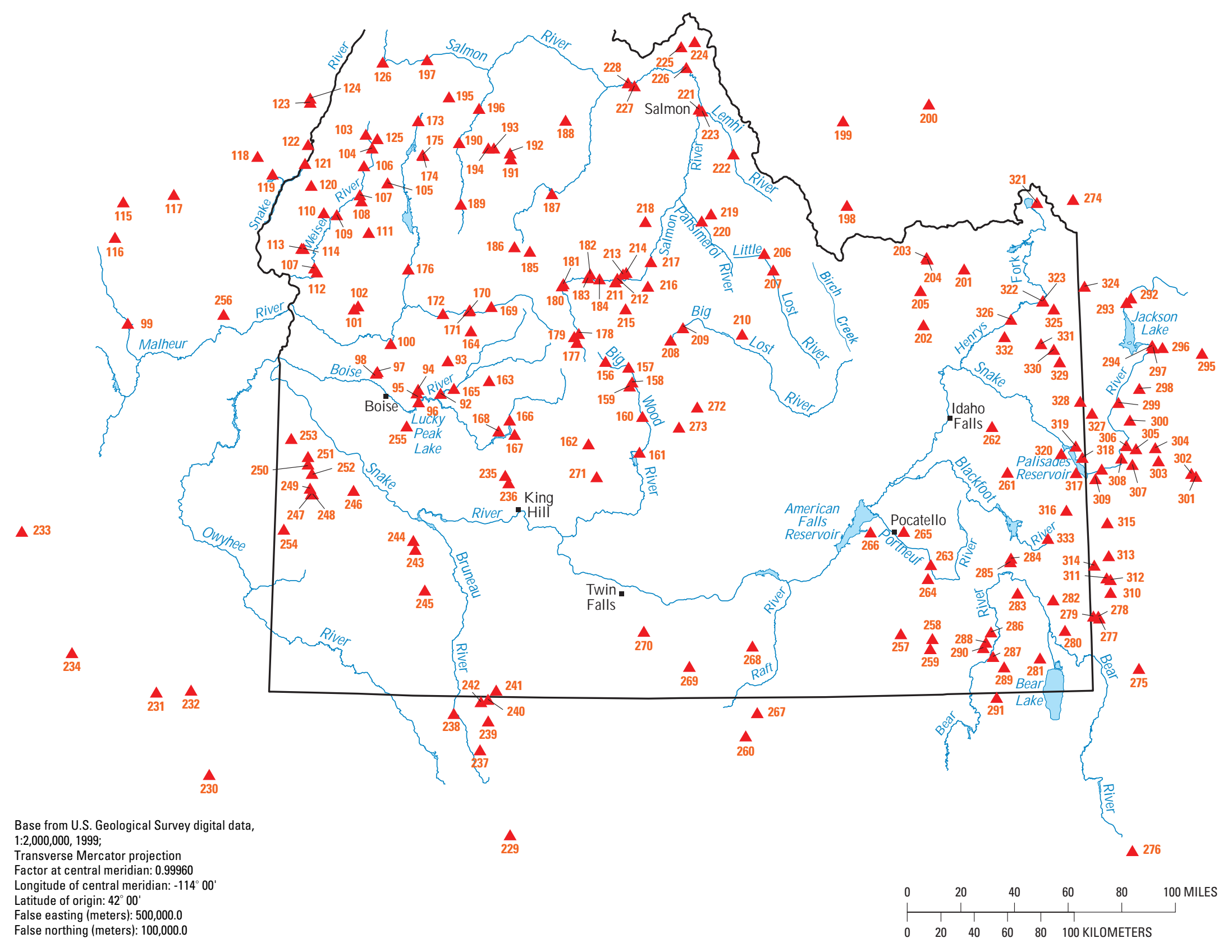

Figure 1. Locations of streamflow-gaging stations in Idaho and bordering States used in regional regression analysis. 
Table 2. Selected data sources used to obtain basin and climatic characteristics for regional regression analysis

[Multiply meter by 3.281 to obtain foot; multiply kilometer $(\mathrm{km})$ by 0.6214 to obtain mile]

\begin{tabular}{|c|c|}
\hline Dataset name & Source description \\
\hline National Elevation Dataset (NED) & $\begin{array}{l}\text { Basin characteristics were calculated using 30-meter resolution digital elevation data } \\
\text { (http://gisdata.usgs.gov/ned/) }\end{array}$ \\
\hline $\begin{array}{l}\text { National Elevation Dataset Hydrologic } \\
\text { Derivatives (NED-H) }\end{array}$ & $\begin{array}{l}\text { Hydrologic derivatives of NED data were developed using procedures similar to those in Stage } 1 \\
\text { processing, using a custom projection for Idaho } \\
\text { (http://edcnts12.cr.usgs.gov/ned-h/about/Stage1.html) }\end{array}$ \\
\hline National Land Cover Dataset (NLCD) & $\begin{array}{l}\text { Vogelmann, J.E., Sohl, T.L., Campbell, P.V., and Shaw, D.M., 1998, Regional land cover charac- } \\
\text { terization using Landsat Thematic Mapper data and ancillary data sources: Environmental } \\
\text { Monitoring and Assessment, v. 51, p. 415-428 (http://edcwww.cr.usgs.gov/programs/lccp/) }\end{array}$ \\
\hline $\begin{array}{l}\text { Idaho map of mean annual } \\
\text { precipitation }^{1}\end{array}$ & $\begin{array}{l}\text { Molnau, M., 1995, Mean annual precipitation, 1961-1990, Idaho: Moscow, University of Idaho, } \\
\text { Agricultural Engineering Department, State Climate Program, scale 1:1,000,000 } \\
\text { (http://snow.ag.uidaho.edu/Climate/reports.html) }\end{array}$ \\
\hline $\begin{array}{l}\text { Western United States average monthly } \\
\text { or annual precipitation }{ }^{2}\end{array}$ & $\begin{array}{l}\text { Daly, C., and Taylor, G., 1998, Western United States average monthly or annual precipitation, } \\
\text { 1961-90, Oregon: Portland, Water and Climate Center of the Natural Resources Conservation } \\
\text { Service, grid-cell resolution } 4 \mathrm{~km} \text { (http://www.ocs.orst.edu/prism/prism_new.html) }\end{array}$ \\
\hline
\end{tabular}

3 , and basin characteristic values obtained for the 333 gages (fig. 1) are presented in table 4 .

All basin and climatic characteristics were calculated in a GIS using Arc/Info programs. For example, the DA program compares adjacent grid cells to develop an outline of the DA upstream from the point of interest on the stream using the 30-meter-resolution digital-elevation data (table 3 ). Then the program counts the number of cells within the DA and multiplies by 30 square meters to determine DA. To convert from square meters to square miles, the program multiplies DA by $3.861 \times 10^{-7}$. Because WATSTORE DA was available for most gages, the GIS-calculated DA then was compared with the WATSTORE DA, and the percent difference between GIS-calculated DA and WATSTORE DA was determined and used to help verify the delineation of basin boundaries. Sites with greater than 10-percent difference between the GIS-calculated and WATSTORE values were flagged and reexamined. Errors in the GIS boundary delineation were corrected by comparing USGS 7.5-minute topographic maps with the original manually planimetered basin boundary. After the GIS basin boundaries were adjusted, basin characteristics were recalculated and rechecked until satisfactory results were obtained. The final GIS-calculated DA is compared with the WATSTORE DA in figure 2. Sev- eral sites with DA fewer than $10 \mathrm{mi}^{2}$ did not meet the criteria of less than 10-percent difference between GIScalculated DA and WATSTORE DA because the resolution of the GIS data was much finer (30 meters, or about $100 \mathrm{ft}$ ) than the map resolution. These sites were examined manually to determine whether the GIS delineation was consistent and correct; if not, the boundaries were adjusted accordingly and basin and climatic characteristics were recalculated. The GIScalculated DA was determined to be appropriate and used for all sites in this study (table 4).

\section{DETERMINATION OF REGIONS FOR REGIONAL REGRESSION ANALYSIS}

In regional flood-frequency analysis, attempts are made to define regions that are hydrologically homogeneous in terms of the characteristics being studied (Haan, 1977). This helps to obtain a better fitting regression equation and reduces standard errors. In this study, eight regions were delineated on the basis of the following factors: (1) grouping of similar basin and climatic characteristics based on a statistical cluster analysis; (2) geographic features, such as large mountain ranges or breaks between mountains and plains; and (3) scientific judgment based on general knowledge of 
the area. Cluster analysis, which is a statistical technique that defines common areas on the basis of the similarity of variables used in the analysis, was used to delineate eight regions in Idaho. The cluster analysis was based on 17 of the 18 basin and climatic characteristics defined by the total variance explained by each characteristic and by eliminating redundant information. Drainage area was not used in this analysis because it is not a region-specific variable. Characteristics from the 333 gages included in the study were used. Characteristics were normalized to a mean of 0 so as not to influence the grouping by differences in units of measurement among the characteristics. Normalization makes the data less dependent on the kind of characteristic. Clustering also was limited to fewer than 13 groups; otherwise, groups were indistinctive or undefinable.

Cluster analysis resulted in six to eight welldefined groups. Other groupings were indistinctive or less well defined. Eight groups were considered optimal because they provided an adequate number of sites in each region for the regression analysis (fig. 3).

Initial grouping on the basis of cluster analysis delineated a large part of the Snake River Plain as one region. However, when the number of possible groups was increased to 10,11 , or 12 , sites on the plain showed more diversity between one another and differences were greater between sites located on the eastern and western sides of the plain. These differences also were apparent in the regionalization study by Thomas and others (1994) and somewhat apparent in the study by Thomas and others (1973), who divided the eastern and western Snake River Plain into separate regions. In keeping with the numbering system of Hortness and Berenbrock (2001), region 7 was divided accordingly and redesignated as regions $7 \mathrm{a}$ and $7 \mathrm{~b}$, which correspond with the western Snake River Plain and eastern Snake River Plain, respectively (fig. 3).

A part of the area commonly referred to as the eastern Snake River Plain (region 0) was excluded from the regionalization for several reasons: (1) Most of the streams in this region either are regulated or are significantly affected by irrigation diversions, (2) several springs with extremely large discharges add significant flow to streams in the region, and (3) the lithology of the area consists mainly of layered basalts that exhibit extremely high rates of infiltration. The effects of these features on the hydrology of the area cannot be characterized by a regional regression approach.

\section{METHODS FOR ESTIMATING PEAK FLOWS FOR GAGED SITES}

Two methods were developed to estimate peak flows at various recurrence intervals for gaged sites

Table 3. Description of selected basin and climatic characteristics used in the final predictive equations

[Multiply meter by 3.281 to obtain foot; multiply kilometer $(\mathrm{km})$ by 0.6214 to obtain mile]

\begin{tabular}{|c|c|}
\hline Characteristic & Description \\
\hline Drainage area $(\mathrm{DA})$ & $\begin{array}{l}\text { Drainage area of the basin that contributes surface runoff, in square miles; estimated using Arc/Info Grid } \\
\text { with 30-meter-resolution digital-elevation models (DEMs) }\end{array}$ \\
\hline Mean basin elevation (E) & $\begin{array}{l}\text { Mean elevation of the basin, in feet above sea level; estimated using Arc/Info Grid and averaging eleva- } \\
\text { tions using 30-meter-resolution DEMs }\end{array}$ \\
\hline Forested area $(\mathrm{F})$ & $\begin{array}{l}\text { Area of the basin containing forest, in percent of total drainage area; estimated using Arc/Info Grid with } \\
\text { a 37-meter-resolution land-cover grid }\end{array}$ \\
\hline Mean annual precipitation $(\mathrm{P})$ & $\begin{array}{l}\text { Mean annual precipitation over the entire drainage area, in inches; estimated using Arc/Info Grid with a } \\
\text { combination of 500-meter (within Idaho) and 4-km (outside of Idaho) resolution precipitation grids }\end{array}$ \\
\hline Basin slope (BS) & $\begin{array}{l}\text { Average slope of the basin, in percent; estimated using the "average maximum technique" in Arc/Info } \\
\text { Grid with 30-meter-resolution DEMs }\end{array}$ \\
\hline $\begin{array}{l}\text { North-facing slopes greater } \\
\text { than } 30 \text { percent (NF30) }\end{array}$ & $\begin{array}{l}\text { Area of north-facing slopes with slopes greater than } 30 \text { percent, in percent of drainage area; estimated } \\
\text { using the "average maximum technique" in Arc/Info Grid with 30-meter-resolution DEMs }\end{array}$ \\
\hline $\begin{array}{l}\text { Slopes greater than } 30 \\
\text { percent }(\mathrm{S} 30)\end{array}$ & $\begin{array}{l}\text { Area with slopes greater than } 30 \text { percent, in percent of drainage area; estimated using the "average maxi- } \\
\text { mum technique" in Arc/Info Grid with 30-meter-resolution DEMs }\end{array}$ \\
\hline
\end{tabular}




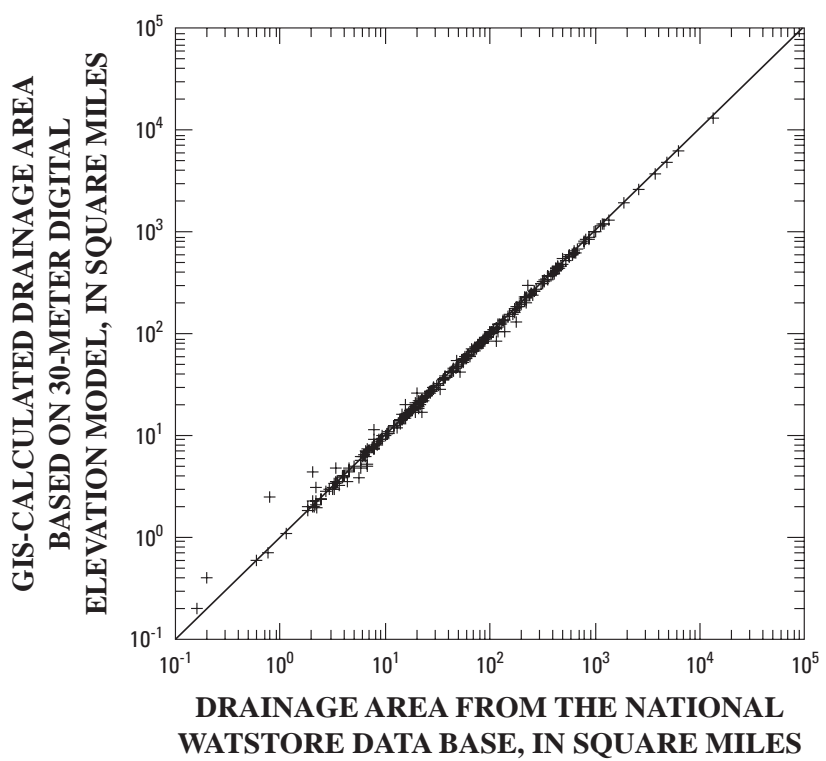

Figure 2. Comparison between GIS-calculated drainage area and national WATSTORE drainage area for streamflow-gaging stations in Idaho and bordering States. (GIS, geographic information system; WATSTORE, Water Data Storage and Retrieval System)

or for an ungaged site near a gaged site on the same stream. These methods and their limitations are explained in this section, and step-by-step procedures and examples for using the methods are given in the section entitled "Application of Methods." If the site in question does not fit in either category, then the method developed for estimating peak flows for ungaged sites on unregulated and undiverted streams, which is explained in the section entitled "Methods for Estimating Peak Flows for Ungaged Sites," can be used.

\section{Gaged Sites}

Flood-frequency estimates for a given stream site typically are presented as a set of exceedance probabilities or, alternatively, recurrence intervals, along with the associated peak flows. Exceedance probability is defined as the probability of exceeding a specified peak flow in a 1-year period and is expressed as decimal fractions less than 1.0 or as percentages less than 100 . A peak flow with an exceedance probability of 0.10 has a 10-percent chance of being exceeded in any given year. Recurrence interval is defined as the number of years, on average, during which the specified peak flow is expected to be exceeded one time and is expressed as number of years. A peak flow with a 10-year recurrence interval is one that, on average, will be exceeded once every 10 years. Recurrence interval and exceedance probability are mathematical inverses of one another; thus, a discharge with an exceedance probability of 0.10 has a recurrence interval of 10 years $\left(\frac{1}{0.10}=10\right)$. Conversely, a peak flow with a recurrence interval of 10 years has an exceedance probability of one-tenth or 0.10 $\left(\frac{1}{10}=0.10\right)$. It is important to remember that recurrence intervals, regardless of length, always refer to the average number of occurrences over a long period of time; for example, a 10-year peak flow is one that might occur about 10 times in a 100-year period, rather than exactly once every 10 years.

Flood-frequency estimates for gaged sites are calculated by fitting some known statistical distribution to the series of annual peak flows. For this study, estimates of peak-flow frequency were calculated by fitting a logPearson Type III distribution to the logarithms (base 10) of the annual peak flows, following the guidelines and using the calculation methods described in Bulletin 17B of the Interagency Advisory Committee on Water Data (1982). The equation for fitting the log-Pearson Type III distribution to an observed series of annual peak flows is as follows:

$$
\log \mathrm{Q}_{\mathrm{T}}=\overline{\mathrm{X}}+\mathrm{KS},
$$

where

$\mathrm{Q}_{\mathrm{T}}$ is $\mathrm{T}$-year peak flow, in cubic feet per second;

$\overline{\mathrm{X}}$ is mean of the log-transformed annual peak flow;

$\mathrm{K} i$ is frequency factor dependent on the recurrence interval and the skew coefficient of the log-transformed annual peak flow; and

$\mathrm{S}$ is standard deviation of the log-transformed annual peak flow.

Values of $\mathrm{K}$ for a wide range of recurrence intervals and skew coefficients are published in Appendix 3 of Bulletin 17B (Interagency Advisory Committee on Water Data, 1982). 


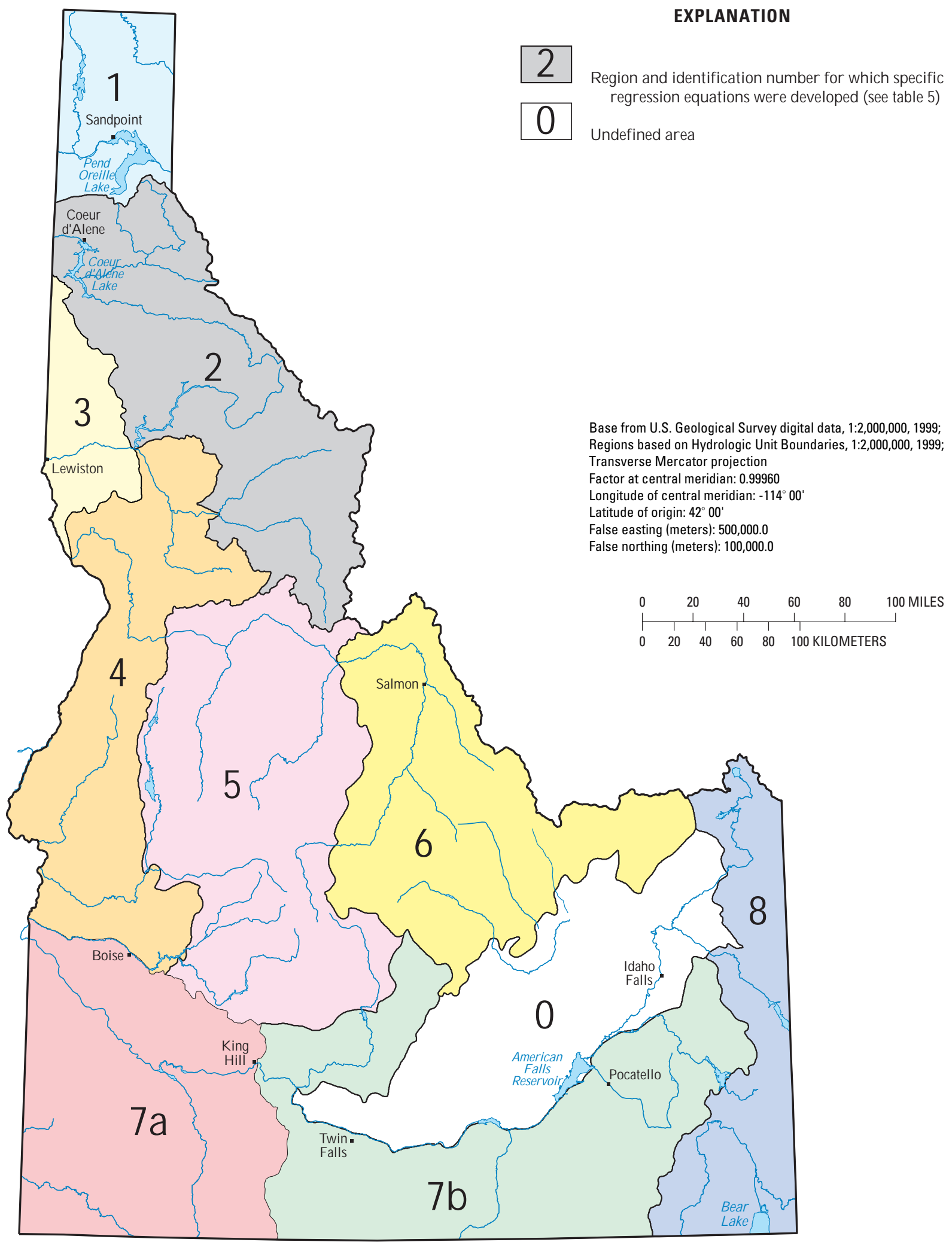

Figure 3. Locations of regions in Idaho used in regional regression analysis. 
A skew coefficient measures the symmetry of the distribution of a set of peak flows about the median of the distribution. A peak-flow distribution with a mean equal to the median is said to have zero skew. A positively skewed distribution has a mean that exceeds the median. One or more extremely large peak flows within a record of significantly smaller peak flows often result in a positive skew coefficient. A negatively skewed distribution has a mean that is less than the median. Several very small peak flows within a record of generally larger peak flows often result in a negative skew.

The calculated skew coefficient for any peak-flow record is very sensitive to extreme peak flows. Therefore, the skew coefficient for a gage with a short period of record might not provide an accurate estimate of the population skew. Thus, a flood-frequency estimate made using equation (1) might not be reliable. A more accurate estimate of skew coefficient can be obtained by weighting the sample (individual gage) skew coefficient with a regional skew coefficient (Interagency Advisory Committee on Water Data, 1982).

A regional skew coefficient is based on regional trends in the skew coefficients calculated from longterm gages. A nationwide regional skew study was conducted by the Interagency Advisory Committee on Water Data (1982), and skew coefficients from longterm gages throughout the Nation were calculated and used to produce a map showing equal lines of regional skew. Kjelstrom and Moffatt (1981) produced regional skew maps of Idaho for rainfall, snowmelt, and rainfallsnowmelt events. Their regional skew map for snowmelt matched the nationwide regional skew map. Therefore, their maps were used to calculate the regional skew for gages in this study. To calculate the weighted skew, the mean square error of regional skew and sample skew are needed. The mean square errors of regional skew from the 1981 maps were 0.18 for rainfall events, 0.15 for snowmelt events, and 0.16 for rainfall-snowmelt events (L.C. Kjelstrom, U.S. Geological Survey, written commun., 1999). Flood-frequency estimates for all gages used in this study were calculated using a weighted skew.

Fitting the log-Pearson Type III distribution to a long series of annual peak flows is fairly straightforward. Often, however, a series of peak flows can include extremely small or large peak flows that depart significantly from the trend in the data (low or high outliers). The peak-flow record also can include peak flows that occurred outside of the period of regularly collected (systematic) record. Such peak flows, known as historical peaks, are often the maximum peak flows known to have occurred. The interpretation of outliers and historical peak information in the fitting process can greatly affect the final flood-frequency estimate. Bulletin 17B (Interagency Advisory Committee on Water Data, 1982) provides guidelines for detecting and interpreting these outliers and provides calculation methods for making appropriate corrections to the distribution to account for their presence.

Bulletin 17B (Interagency Advisory Committee on Water Data, 1982) guidelines were followed for determining flood-frequency estimates for the 333 gages that formed the database (table 5). The period of known peak flows and the number of years of known peak flows also are listed in table 5. For gages not listed in table 5, flood-frequency estimates can be calculated using procedures described in this section and in Bulletin 17B (Interagency Advisory Committee on Water Data, 1982).

\section{Ungaged Sites Near Gaged Sites on the Same Stream}

Flood frequencies for ungaged sites near gaged sites on the same stream can be estimated using a ratio of drainage area for the ungaged site to drainage area for the gaged site as shown in the following equation (the drainage-area ratio $\mathrm{DA}_{\mathrm{u}} / \mathrm{DA}_{\mathrm{g}}$ should be approximately between 0.5 and 1.5 ):

$$
\mathrm{Q}_{\mathrm{u}}=\left(\frac{\mathrm{DA}_{\mathrm{u}}}{\mathrm{DA}_{\mathrm{g}}}\right)^{a} \mathrm{Q}_{\mathrm{g}},
$$

where

$\mathrm{Q}_{\mathrm{u}}$ is peak flow for the selected flood frequency for the ungaged site,

$\mathrm{DA}_{\mathrm{u}}$ is drainage area for the ungaged site,

$\mathrm{DA}_{\mathrm{g}}$ is drainage area for the gaged site,

$a$ is exponent for drainage area for each hydrologic region (table 6), and

$\mathrm{Q}_{\mathrm{g}}$ is peak flow for the selected flood frequency for the gaged site. 
The exponent, $a$, was determined by regressing the logarithms of the T-year flood $(\mathrm{T}=2,5,10,25,50$, 100,200 , and 500) against the logarithm of DA for each region and averaging the regression coefficients for the eight recurrence intervals. The values of the exponent for each region are shown in table 6 .

If an ungaged site is between two gaged sites, the flood-frequency data for the ungaged site can be estimated by interpolating between values for the two gages using the following equation:

$$
Q_{u}=\left[\frac{Q_{g_{1}}\left(D A_{g_{2}}-D A_{u}\right)+Q_{g_{2}}\left(D A_{u}-D A_{g_{1}}\right)}{\left(D A_{g_{2}}-D A_{g_{1}}\right)}\right],
$$

where

$\mathrm{Q}_{\mathrm{u}}$ is peak flow for the selected frequency for the ungaged site between gaged sites 1 and 2 ,

$\mathrm{Q}_{1}$ is peak flow for the selected flood frequency for the upstream gage,

$\mathrm{DA}_{2}$ is drainage area for the downstream gage,

$\mathrm{DA}_{\mathrm{u}}$ is drainage area for the ungaged site,

$\mathrm{Q}_{\mathrm{g}_{2}}$ is peak flow for the selected flood frequency for the downstream gage, and

$\mathrm{DA}_{g_{1}}$ is drainage area for the upstream gage.

\section{METHODS FOR ESTIMATING PEAK FLOWS FOR UNGAGED SITES}

Two regional regression methods were used to develop equations for estimating peak flows for ungaged sites on unregulated and undiverted streams in Idaho. The first method used generalized least-squares (GLS) regression to define a set of predictive equations that related peak flow at the 2-, 5-, 10-, 25-, 50-, 100-, 200-, and 500-year recurrence intervals to selected basin characteristics for each hydrologic region in Idaho. The second method, the region-of-influence (ROI) method (Tasker and Slade, 1994), was used to develop unique regression equations for each ungaged site on the basis of an optimal set of gaged sites with values of basin and climatic characteristics that were similar to those
Table 6. Value of exponent, $a$, for regions in Idaho used in regional regression analysis

\begin{tabular}{c|c||c|c}
\hline Region & $\begin{array}{c}\text { Exponent } \\
\boldsymbol{a}\end{array}$ & Region & $\begin{array}{c}\text { Exponent } \\
\boldsymbol{a}\end{array}$ \\
\hline 1 & 0.65 & 6 & 0.80 \\
\hline 2 & 0.88 & $7 \mathrm{a}$ & 0.77 \\
\hline 3 & 0.84 & $7 \mathrm{~b}$ & 0.65 \\
\hline 4 & 0.85 & 8 & 0.90 \\
\hline 5 & 0.94 & \multicolumn{2}{|c}{} \\
\hline
\end{tabular}

of the ungaged site. GLS regression also was used to develop the predictive equations for the ROI method. Neither method was reliable for the eastern Snake River Plain (region 0) (see section entitled "Determination of Regions" for more explanation).

\section{Regional Regression Method}

For both regression methods, all peak-flow data and basin and climatic characteristics were transformed to base-10 logarithms. Before transformation of the data, a value of 1 was added to data that were a percentage measure (for example, forest cover). This would ensure that 0 values, which cannot be transformed, would not result. Also, mean basin elevation (E) values were divided by 1,000 before transformation to allow for more convenient coefficients in the final equations. Transformation was performed to obtain linear relations between explanatory variables (basin and climatic characteristics) and response variables (T-year peak flows) and to achieve equal variance about the regression line.

Ordinary least-squares (OLS) linear regression was used initially to determine the best combination of transformed explanatory variables to use in the GLS regression equation for each region. Initially, $18 \mathrm{ex}-$ planatory variables were considered. The best combination of the explanatory variables was based on minimizing Mallow's Cp, the PRESS statistic, the standard error of the estimate (SEE) (Helsel and Hirsch, 1992), and passing of diagnostic checks to test for outliers, high-influence values, and multicollinearity between explanatory variables. For example, the best combination of explanatory variables for region 1 was drainage 
area, mean basin elevation, and percent forest cover. These three variables were highly significant (the $p$ values from the T-statistics were less than 0.0001) in the OLS regression.

OLS regression is an appropriate and efficient regression analysis to use when the peak flows for gaged sites (response variables) are independent of each other (no correlation exists between pairs of sites) and when the record lengths and variability of the peak flows for different gaged sites are approximately equal. Records of peak flow from gages on the same stream, on different streams within the same basins, or even on streams in adjacent basins can be highly correlated, however, because the peak flows might have resulted from the same rainfall-snowmelt events. Peak-flow record lengths for sites used in this study ranged from 10 to 91 years and, thus, cannot be considered equal for all sites. Peak flows for gaged sites ranged from 4 to $149,000 \mathrm{ft}^{3} / \mathrm{s}$ and cannot be considered equal for all sites. For these reasons, OLS regression was used only as an exploratory technique.

GLS regression, as described by Stedinger and Tasker (1985), is a regression technique that takes into account the correlation between sites, as well as the differences in record lengths and variability of peak flows for gaged sites. These factors are accounted for in GLS regression by assigning different weights to each observation of the peak flow on the basis of its contribution to the total variance of the sample flow statistics.

GLS regression was used to calculate the final coefficients and measures of accuracy for the regional regression equations for each region. The computer program GLSNET (Tasker and Stedinger, 1989) was used to develop the regional regression equations and error results. To account for the effects of cross correlation, the GLS regression used a "best-fit" mathematical relation between sample cross-correlation coefficients and distance between sites for site pairs with long periods (at least 30 years) of concurrent record. This bestfit relation then was used to populate a cross-correlation matrix for the sites contained in each region. The matrix was used to give less weight to sites whose concurrent peak flows were correlated with those for other sites. The variability of peak flows for each site was measured by the standard deviation of the population of all peak flows for that site. The standard deviation of the population of peak flows for each site was calculated from a regression of the sample standard deviations against drainage area. These regression estimates of the standard deviations were used to assign weights to peak flows. Finally, the length of record at each site was used as a direct measure of the relative reliability of the T-year flow estimates calculated from those records. Less weight was given to sites with shorter periods of record.

\section{Region-of-Influence Method}

The ROI method (Tasker and Slade, 1994) was used to estimate T-year peak flows for ungaged sites from regression relations between T-year peak flows and basin and climatic characteristics for a unique subset of gaged sites. This unique subset of gaged sites, first suggested by Acreman and Wiltshire (1987), was described by Burn (1990a, 1990b) as the region of influence for the ungaged site, hence the name of the method. The unique subset of gaged sites is defined as the number, $\mathrm{N}$, of gaged sites nearest to the ungaged site (Pope and Tasker, 1999), where nearest is determined from the Euclidean distance metric:

$$
\mathrm{d}_{\mathrm{ij}}=\left[\sum_{\mathrm{k}=1}^{\mathrm{p}} \frac{\left(\mathrm{x}_{\mathrm{ik}}-\mathrm{x}_{\mathrm{jk}}\right)^{2}}{\mathrm{sd}\left(\mathrm{x}_{\mathrm{k}}\right)}\right]^{\frac{1}{2}},
$$

where

$\mathrm{d}_{\mathrm{ij}}$ is distance between two sites $\mathrm{i}$ and $\mathrm{j}$ in terms of basin and climatic characteristics,

$\mathrm{p}$ is number of basin and climatic characteristics used to calculate $\mathrm{d}_{\mathrm{ij}}$,

$\mathrm{x}_{\mathrm{ik}}$ is $\mathrm{k}^{\text {th }}$ basin and climatic characteristics at site $\mathrm{i}$,

$\mathrm{x}_{\mathrm{jk}}$ is $\mathrm{k}^{\text {th }}$ basin and climatic characteristics at site $\mathrm{j}$,

$\mathrm{x}_{\mathrm{k}}$ is $\mathrm{k}^{\text {th }}$ basin and climatic characteristic, and $\mathrm{sd}\left(\mathrm{x}_{\mathrm{k}}\right)$ is sample standard deviation for $\mathrm{x}_{\mathrm{k}}$.

The distance metric measures the multidimensional distance between two sites defined in terms of the basin and climatic characteristics.

This distance metric is directly analogous to the more familiar equation for distance, $\mathrm{D}=\left[\left(\mathrm{x}_{2}-\mathrm{x}_{1}\right)^{2}+\right.$ $\left.\left(\mathrm{y}_{2}-\mathrm{y}_{1}\right)^{2}\right]^{\frac{1}{2}}$ in a two-dimensional rectangular coordinate 
system. The only difference between this equation and equation (4) is the use of sample standard deviation to standardize the different basin and climatic characteristics (remove the effects of disproportional units) and the notational difference of using an additional subscript (k) rather than changing variable symbols (x, y).

The ROI for an ungaged site is determined using equation (4) by first computing the distances $\left(\mathrm{d}_{\mathrm{ij}}\right)$ between the ungaged site and all the gaged sites. The distances are ranked and the $\mathrm{N}$ sites with the smallest $\mathrm{d}_{\mathrm{ij}}$ compose the ROI for that ungaged site. This technique is analogous to separating an area into similar physiographic, climatic, and (or) hydrologic regions (regionalization) as was done for the previous regression method. Once the ROI is determined, GLS regression techniques are used to develop the unique predictive relations between T-year peak flows and basin characteristics for the ungaged site.

The basin and climatic characteristics used to define an ROI need not be the same explanatory variables used in the subsequent GLS regression. For example, in a flood-frequency analysis in North Carolina for which the ROI method was used, the set of characteristics used as explanatory variables was a subset of the characteristics used to define $\mathrm{d}_{\mathrm{ij}}$ (Pope and Tasker, 1999).

The number of gaged sites and basin characteristics used to define the ROI and perform the GLS regression were selected by trial and error, using a calculated root-mean-squared error (RMSE) as the criterion for selection. RMSE was calculated by removing one site at a time from the database and using the remaining sites to define a new regression equation for the site and to calculate an estimate of the peak flow. RMSE was calculated as the square root of the arithmetic mean of the differences between the estimated and calculated values of peak flow for each site. Then RMSEs were compared with results from the regional regression method for each region.

\section{RESULTS OF ESTIMATING PEAK FLOWS FOR UNGAGED SITES}

Two methods were developed to estimate peak flows at various recurrence intervals for ungaged sites on unregulated and undiverted streams in Idaho. These methods are explained in a previous section entitled "Methods for Estimating Peak Flows for Ungaged Sites," and step-by-step procedures and examples of using the methods are given in the section entitled "Application of Methods."

\section{Regional Regression Analysis}

GLS regression equations for recurrence intervals of $2,5,10,25,50,100,200$, and 500 years were developed for all regions (table 7). Drainage area (DA) was included in regression equations for all regions; mean basin elevation (E), for five of the regions; and mean annual precipitation $(\mathrm{P})$, for two of the regions. At least one of the following variables-forest cover $(\mathrm{F})$, northfacing slopes greater than 30 percent (NF30), basin slope (BS), and slopes greater than 30 percent (S30)was included in regression equations for three regions. No equation included more than three explanatory variables. Region $7 \mathrm{~b}$ was the only region that included only one explanatory variable (DA). Three of the explanatory variables - NF30, BS, and S30 - have not been used previously in regional regression equations for estimation of flood frequency in Idaho.

The standard error of the regression model and the average standard error of prediction also are listed in table 7. The standard error of the regression model is a measure of how well the regression model fits the data used to construct it. This error term is also often termed the standard error of estimate. The average standard error of prediction is the sum of two componentsmodel error plus sampling error-which results from estimating model parameters from samples of the population. The model error is a characteristic of the model and is a constant for all sites. The sampling error for a given site, however, depends on the values of the explanatory variables used to develop the peak-flow estimate at that site. The error of prediction, therefore, varies from site to site. The standard error of prediction provides a better overall measure of a model's predictive reliability than does the model error. A more rigorous mathematical description of these errors and how to convert them from logarithms (base-10 units) to percent errors are given in a report by Pope and Tasker (1999, p. 12).

Standard errors of the model were different for each region and for each recurrence interval (table 7). The largest and smallest average standard errors of the model were +131 percent and -56.6 percent, respectively. The range of model standard errors for all recurrence intervals was narrowest for region 5. The range 
Table 7. Predictive regression equations and their accuracy in estimating peak flows for ungaged sites on unregulated and undiverted streams in Idaho

[Q, peak flow, in cubic feet per second; DA, drainage area, in square miles; E, mean basin elevation, in feet; F, percentage of forest cover in the basin; P, mean annual precipitation, in inches; NF30, percentage of north-facing slopes greater than 30 percent; S30, percentage of slopes greater than 30 percent; BS, average basin slope, in percent]

\begin{tabular}{|c|c|c|}
\hline $\begin{array}{l}\text { Peak-flow regression equations for given recurrence interval } \\
\qquad(2 \text { to } 500 \text { years) }\end{array}$ & $\begin{array}{c}\text { Standard error } \\
\text { of model } \\
\text { (percent) }\end{array}$ & $\begin{array}{c}\text { Standard error } \\
\text { of prediction } \\
\text { (percent) }\end{array}$ \\
\hline \multicolumn{3}{|c|}{ Region 1 (Equations based on data from 21 gaging stations) } \\
\hline $\mathrm{Q}_{2}=2.52 \mathrm{DA}^{0.775}(\mathrm{E} / 1,000)^{3.32}(\mathrm{~F}+1)^{-0.504}$ & +69.0 to -40.8 & +78.4 to -43.9 \\
\hline $\mathrm{Q}_{5}=23.0 \mathrm{DA}{ }^{0.720}(\mathrm{E} / 1,000)^{3.36}(\mathrm{~F}+1)^{-0.885}$ & +53.3 to -34.8 & +61.1 to -37.9 \\
\hline $\mathrm{Q}_{10}=81.5 \mathrm{DA}^{0.687}(\mathrm{E} / 1,000)^{3.40}(\mathrm{~F}+1)^{-1.10}$ & +49.0 to -32.9 & +56.8 to -36.2 \\
\hline $\mathrm{Q}_{25}=339 \mathrm{DA}^{0.649}(\mathrm{E} / 1,000)^{3.44}(\mathrm{~F}+1)^{-1.36}$ & +48.5 to -32.6 & +57.1 to -36.3 \\
\hline $\mathrm{Q}_{50}=876 \mathrm{DA}{ }^{0.623}(\mathrm{E} / 1,000)^{3.47}(\mathrm{~F}+1)^{-1.53}$ & +50.6 to -33.6 & +60.1 to -37.6 \\
\hline $\mathrm{Q}_{100}=2,080 \mathrm{DA}^{0.597}(\mathrm{E} / 1,000)^{3.49}(\mathrm{~F}+1)^{-1.68}$ & +54.2 to -35.2 & +64.8 to -39.3 \\
\hline $\mathrm{Q}_{200}=4,660 \mathrm{DA}{ }^{0.572}(\mathrm{E} / 1,000)^{3.52}(\mathrm{~F}+1)^{-1.82}$ & +58.9 to -37.1 & +70.8 to -41.4 \\
\hline $\mathrm{Q}_{500}=12,600 \mathrm{DA}^{0.540}(\mathrm{E} / 1,000)^{3.56}(\mathrm{~F}+1)^{-2.00}$ & +66.5 to -39.9 & +80.1 to -44.5 \\
\hline \multicolumn{3}{|c|}{ Region 2 (Equations based on data from 44 gaging stations) } \\
\hline $\mathrm{Q}_{2}=0.742 \mathrm{DA}^{0.897} \mathrm{P}^{0.935}$ & +60.2 to -37.6 & +64.2 to -39.1 \\
\hline $\mathrm{Q}_{5}=1.50 \mathrm{DA}^{0.888}(\mathrm{E} / 1,000)^{-0.330} \mathrm{P}^{0.992}$ & +60.1 to -37.5 & +64.3 to -39.1 \\
\hline $\mathrm{Q}_{10}=2.17 \mathrm{DA}^{0.884}(\mathrm{E} / 1,000)^{-0.538} \mathrm{P}^{1.04}$ & +61.4 to -38.0 & +65.8 to -39.7 \\
\hline $\mathrm{Q}_{25}=3.24 \mathrm{DA}^{0.879}(\mathrm{E} / 1,000)^{-0.788} \mathrm{P}^{1.10}$ & +63.9 to -39.0 & +68.7 to -40.7 \\
\hline $\mathrm{Q}_{50}=4.22 \mathrm{DA}^{0.876}(\mathrm{E} / 1,000)^{-0.962} \mathrm{P}^{1.14}$ & +66.1 to -39.8 & +71.4 to -41.6 \\
\hline $\mathrm{Q}_{100}=5.39 \mathrm{DA}^{0.874}(\mathrm{E} / 1,000)^{-1.13} \mathrm{P}^{1.18}$ & +68.5 to -40.6 & +74.1 to -42.6 \\
\hline $\mathrm{Q}_{200}=6.75 \mathrm{DA}^{0.872}(\mathrm{E} / 1,000)^{-1.29} \mathrm{P}^{1.21}$ & +71.1 to -41.5 & +77.1 to -43.5 \\
\hline $\mathrm{Q}_{500}=8.90 \mathrm{DA}^{0.869}(\mathrm{E} / 1,000)^{-1.49} \mathrm{P}^{1.26}$ & +74.7 to -42.8 & +81.3 to -44.8 \\
\hline \multicolumn{3}{|c|}{ Region 3 (Equations based on data from 26 gaging stations) } \\
\hline $\mathrm{Q}_{2}=26.3 \mathrm{DA}^{0.864}(\mathrm{E} / 1,000)^{-0.502}$ & +78.3 to -43.9 & +86.4 to -46.4 \\
\hline $\mathrm{Q}_{5}=127 \mathrm{DA}^{0.842}(\mathrm{E} / 1,000)^{-1.31}$ & +52.1 to -34.3 & +58.6 to -36.9 \\
\hline $\mathrm{Q}_{10}=265 \mathrm{DA}^{0.837}(\mathrm{E} / 1,000)^{-1.68}$ & +45.2 to -31.1 & +51.8 to -34.1 \\
\hline $\mathrm{Q}_{25}=504 \mathrm{DA}^{0.833}(\mathrm{E} / 1,000)^{-1.95}$ & +43.0 to -30.1 & +50.3 to -33.5 \\
\hline $\mathrm{Q}_{50}=719 \mathrm{DA}^{0.832}(\mathrm{E} / 1,000)^{-2.08}$ & +43.9 to -30.5 & +51.9 to -34.2 \\
\hline $\mathrm{Q}_{100}=965 \mathrm{DA}^{0.831}(\mathrm{E} / 1,000)^{-2.18}$ & +46.3 to -31.6 & +55.1 to -35.5 \\
\hline $\mathrm{Q}_{200}=1,240 \mathrm{DA}^{0.831}(\mathrm{E} / 1,000)^{-2.26}$ & +49.7 to -33.2 & +59.4 to -37.3 \\
\hline $\mathrm{Q}_{500}=1,660 \mathrm{DA}^{0.832}(\mathrm{E} / 1,000)^{-2.35}$ & +55.4 to -35.6 & +66.2 to -39.8 \\
\hline
\end{tabular}


Table 7. Predictive regression equations and their accuracy in estimating peak flows for ungaged sites on unregulated and undiverted streams in Idaho-Continued

\begin{tabular}{|c|c|c|}
\hline $\begin{array}{l}\text { Peak-flow regression equations for given recurrence interval } \\
\qquad(2 \text { to } 500 \text { years) }\end{array}$ & $\begin{array}{l}\text { Standard error } \\
\text { of model } \\
\text { (percent) }\end{array}$ & $\begin{array}{l}\text { Standard error } \\
\text { of prediction } \\
\text { (percent) }\end{array}$ \\
\hline \multicolumn{3}{|c|}{ Region 4 (Equations based on data from 60 gaging stations) } \\
\hline $\mathrm{Q}_{2}=16.3 \mathrm{DA}^{0.893}(\mathrm{E} / 1,000)^{-0.121}$ & +80.5 to -44.6 & +83.5 to -45.5 \\
\hline $\mathrm{Q}_{5}=46.3 \mathrm{DA}^{0.874}(\mathrm{E} / 1,000)^{-0.459}$ & +66.6 to -40.0 & +69.1 to -40.9 \\
\hline $\mathrm{Q}_{10}=79.2 \mathrm{DA}^{0.863}(\mathrm{E} / 1,000)^{-0.628}$ & +61.2 to -37.9 & +63.6 to -38.9 \\
\hline $\mathrm{Q}_{25}=139 \mathrm{DA}^{0.852}(\mathrm{E} / 1,000)^{-0.801}$ & +56.9 to -36.3 & +59.5 to -37.3 \\
\hline $\mathrm{Q}_{50}=198 \mathrm{DA}^{0.844}(\mathrm{E} / 1,000)^{-0.910}$ & +55.2 to -35.6 & +57.7 to -36.6 \\
\hline $\mathrm{Q}_{100}=273 \mathrm{DA}^{0.837}(\mathrm{E} / 1,000)^{-1.01}$ & +54.2 to -35.1 & +56.9 to -36.3 \\
\hline $\mathrm{Q}_{200}=365 \mathrm{DA}^{0.831}(\mathrm{E} / 1,000)^{-1.10}$ & +53.8 to -35.0 & +56.6 to -36.1 \\
\hline $\mathrm{Q}_{500}=521 \mathrm{DA}^{0.822}(\mathrm{E} / 1,000)^{-1.20}$ & +53.9 to -35.0 & +56.9 to -36.3 \\
\hline \multicolumn{3}{|c|}{ Region 5 (Equations based on data from 46 gaging stations) } \\
\hline $\mathrm{Q}_{2}=0.0297 \mathrm{DA}^{0.995} \mathrm{P}^{2.20}(\mathrm{NF} 30+1)^{-0.664}$ & +43.6 to -30.4 & +46.7 to -31.8 \\
\hline $\mathrm{Q}_{5}=0.0992 \mathrm{DA}^{0.970} \mathrm{P}^{1.92}(\mathrm{NF} 30+1)^{-0.602}$ & +41.7 to -29.4 & +44.8 to -30.9 \\
\hline $\mathrm{Q}_{10}=0.178 \mathrm{DA}^{0.957} \mathrm{P}^{1.79}(\mathrm{NF} 30+1)^{-0.571}$ & +41.7 to -29.4 & +45.0 to -31.1 \\
\hline $\mathrm{Q}_{25}=0.319 \mathrm{DA}^{0.943} \mathrm{P}^{1.66}(\mathrm{NF} 30+1)^{-0.538}$ & +42.3 to -29.7 & +46.0 to -31.5 \\
\hline $\mathrm{Q}_{50}=0.456 \mathrm{DA}^{0.934} \mathrm{P}^{1.58}(\mathrm{NF} 30+1)^{-0.517}$ & +43.1 to -30.1 & +47.1 to -32.0 \\
\hline $\mathrm{Q}_{100}=0.620 \mathrm{DA}^{0.926} \mathrm{P}^{1.52}(\mathrm{NF} 30+1)^{-0.499}$ & +44.1 to -30.6 & +48.4 to -32.6 \\
\hline $\mathrm{Q}_{200}=0.813 \mathrm{DA}^{0.919} \mathrm{P}^{1.46}(\mathrm{NF} 30+1)^{-0.483}$ & +45.3 to -31.2 & +49.8 to -33.2 \\
\hline $\mathrm{Q}_{500}=1.12 \mathrm{DA}^{0.911} \mathrm{P}^{1.39}(\mathrm{NF} 30+1)^{-0.464}$ & +46.9 to -31.9 & +51.9 to -34.2 \\
\hline \multicolumn{3}{|c|}{ Region 6 (Equations based on data from 31 gaging stations) } \\
\hline $\mathrm{Q}_{2}=0.000258 \mathrm{DA}^{0.893} \mathrm{P}^{3.15}$ & +71.2 to -41.6 & +76.5 to -43.4 \\
\hline $\mathrm{Q}_{5}=0.00223 \mathrm{DA}^{0.846} \mathrm{P}^{2.68}$ & +63.9 to -39.0 & +68.8 to -40.8 \\
\hline $\mathrm{Q}_{10}=0.00632 \mathrm{DA}^{0.824} \mathrm{P}^{2.45}$ & +62.9 to -38.6 & +67.9 to -40.4 \\
\hline $\mathrm{Q}_{25}=0.0181 \mathrm{DA}^{0.801} \mathrm{P}^{2.22}$ & +63.4 to -38.8 & +68.8 to -40.8 \\
\hline $\mathrm{Q}_{50}=0.0346 \mathrm{DA}^{0.787} \mathrm{P}^{2.08}$ & +64.4 to -39.2 & +70.2 to -41.2 \\
\hline $\mathrm{Q}_{100}=0.0607 \mathrm{DA}^{0.775} \mathrm{P}^{1.96}$ & +65.8 to -39.7 & +71.8 to -41.8 \\
\hline $\mathrm{Q}_{200}=0.100 \mathrm{DA}^{0.763} \mathrm{P}^{1.85}$ & +67.3 to -40.2 & +73.8 to -42.4 \\
\hline $\mathrm{Q}_{500}=0.180 \mathrm{DA}^{0.750} \mathrm{P}^{1.73}$ & +69.6 to -41.0 & +76.5 to -43.3 \\
\hline
\end{tabular}


Table 7. Predictive regression equations and their accuracy in estimating peak flows for ungaged sites on unregulated and undiverted streams in Idaho-Continued

\begin{tabular}{|c|c|c|}
\hline $\begin{array}{l}\text { Peak-flow regression equations for given recurrence interval } \\
\qquad \text { ( } 2 \text { to } 500 \text { years) }\end{array}$ & $\begin{array}{l}\text { Standard error } \\
\text { of model } \\
\text { (percent) }\end{array}$ & $\begin{array}{l}\text { Standard error } \\
\text { of prediction } \\
\text { (percent) }\end{array}$ \\
\hline \multicolumn{3}{|c|}{ Region 7a (Equations based on data from 28 gaging stations) } \\
\hline $\mathrm{Q}_{2}=2.28 \mathrm{DA}^{0.759}(\mathrm{E} / 1,000)^{0.769}$ & +74.8 to -42.8 & +82.3 to -45.2 \\
\hline $\mathrm{Q}_{5}=27.3 \mathrm{DA}^{0.762}(\mathrm{E} / 1,000)^{-0.211}$ & +59.9 to -37.5 & +66.6 to -40.0 \\
\hline $\mathrm{Q}_{10}=88.4 \mathrm{DA}^{0.766}(\mathrm{E} / 1,000)^{-0.669}$ & +55.2 to -35.6 & +62.2 to -38.3 \\
\hline $\mathrm{Q}_{25}=286 \mathrm{DA}^{0.771}(\mathrm{E} / 1,000)^{-1.12}$ & +52.9 to -34.6 & +60.6 to -37.7 \\
\hline $\mathrm{Q}_{50}=592 \mathrm{DA}^{0.774}(\mathrm{E} / 1,000)^{-1.41}$ & +53.1 to -34.7 & +61.4 to -38.0 \\
\hline $\mathrm{Q}_{100}=1,120 \mathrm{DA}^{0.778}(\mathrm{E} / 1,000)^{-1.65}$ & +54.4 to -35.2 & +63.3 to -38.8 \\
\hline $\mathrm{Q}_{200}=1,970 \mathrm{DA}^{0.781}(\mathrm{E} / 1,000)^{-1.87}$ & +56.5 to -36.1 & +66.2 to -39.8 \\
\hline $\mathrm{Q}_{500}=3,860 \mathrm{DA}^{0.784}(\mathrm{E} / 1,000)^{-2.13}$ & +60.4 to -37.6 & +71.1 to -41.5 \\
\hline \multicolumn{3}{|c|}{ Region 7b (Equations based on data from 17 gaging stations) } \\
\hline $\mathrm{Q}_{2}=10.2 \mathrm{DA}^{0.611}$ & +131 to -56.6 & +143 to -58.8 \\
\hline $\mathrm{Q}_{5}=17.1 \mathrm{DA}^{0.624}$ & +95.3 to -48.8 & +104 to -50.9 \\
\hline $\mathrm{Q}_{10}=22.4 \mathrm{DA}^{0.633}$ & +79.7 to -44.4 & +86.9 to -46.5 \\
\hline $\mathrm{Q}_{25}=29.9 \mathrm{DA}^{0.644}$ & +66.9 to -40.1 & +73.5 to -42.3 \\
\hline $\mathrm{Q}_{50}=35.7 \mathrm{DA}^{0.653}$ & +61.7 to -38.1 & +68.0 to -40.5 \\
\hline $\mathrm{Q}_{100}=41.6 \mathrm{DA}^{0.662}$ & +59.5 to -37.3 & +66.1 to -39.8 \\
\hline $\mathrm{Q}_{200}=47.5 \mathrm{DA}^{0.672}$ & +60.0 to -37.5 & +66.9 to -40.1 \\
\hline $\mathrm{Q}_{500}=55.5 \mathrm{DA}^{0.686}$ & +64.1 to -39.1 & +71.8 to -41.8 \\
\hline \multicolumn{3}{|c|}{ Region 8 (Equations based on data from 60 gaging stations) } \\
\hline $\mathrm{Q}_{2}=1.49 \mathrm{DA}^{0.942} \mathrm{BS}^{1.15}(\mathrm{~S} 30+1)^{-0.563}$ & +82.9 to -45.3 & +86.9 to -46.5 \\
\hline $\mathrm{Q}_{5}=1.93 \mathrm{DA}^{0.915} \mathrm{BS}^{1.53}(\mathrm{~S} 30+1)^{-0.862}$ & +76.1 to -43.2 & +79.8 to -44.4 \\
\hline $\mathrm{Q}_{10}=2.10 \mathrm{DA}^{0.903} \mathrm{BS}^{1.75}(\mathrm{~S} 30+1)^{-1.03}$ & +74.7 to -42.7 & +78.3 to -43.9 \\
\hline $\mathrm{Q}_{25}=2.22 \mathrm{DA}^{0.892} \mathrm{BS}^{1.99}(\mathrm{~S} 30+1)^{-1.21}$ & +74.5 to -42.7 & +78.2 to -43.9 \\
\hline $\mathrm{Q}_{50}=2.26 \mathrm{DA}^{0.886} \mathrm{BS}^{2.15}(\mathrm{~S} 30+1)^{-1.33}$ & +75.0 to -42.9 & +78.9 to -44.1 \\
\hline $\mathrm{Q}_{100}=2.27 \mathrm{DA}^{0.882} \mathrm{BS}^{2.31}(\mathrm{~S} 30+1)^{-1.44}$ & +75.9 to -43.1 & +79.9 to -44.4 \\
\hline $\mathrm{Q}_{200}=2.25 \mathrm{DA}^{0.878} \mathrm{BS}^{2.45}(\mathrm{~S} 30+1)^{-1.54}$ & +77.0 to -43.5 & +81.2 to -44.8 \\
\hline $\mathrm{Q}_{500}=2.22 \mathrm{DA}^{0.874} \mathrm{BS}^{2.62}(\mathrm{~S} 30+1)^{-1.67}$ & +78.8 to -44.1 & +83.2 to -45.4 \\
\hline
\end{tabular}


of model standard errors for 2-, 5-, and 10-year recurrence intervals was widest for region $7 \mathrm{~b}$ and, for 25 through 500-year recurrence intervals, was widest for region 8 . The largest and smallest average standard errors of prediction ranged from +143 percent to -58.8 percent (table 7). The range of average standard errors of prediction was narrowest for region 5. Model and prediction errors generally were closer to 0 for the middle recurrence intervals $(5,10,25$, and 50 years) and farther from 0 for the lower and upper recurrence intervals $(2,100,200$, and 500 years). Basically, results of average standard errors of prediction were similar to results of model standard errors.

Average standard errors from these regression equations were compared with the average standard errors from previous regression studies in Idaho (table 1). The average standard errors of prediction in table 7 were converted to a single average standard error of prediction, in percent, by procedures described by Aitchison and Brown (1957). This single value was required for comparison with a single value from previous studies. For this study, average standard errors of prediction for $\mathrm{Q}_{100}$ in all regions ranged from a minimum of 41 percent for region 5 to a maximum of 72 percent for region 8 . Standard errors generally were smallest for region 5 and largest for region 8. Standard errors from this study were consistently smaller and the ranges narrower than those from previous studies (table 1). No real comparison can be made with Kjelstrom and Moffatt's study (1981) because no distinction was made in errors between frequencies. Only the maximum error of 62 percent from the study of Thomas and others (1973) was smaller than the maximum error from this study (77 percent).

\section{Region-of-Influence Analysis}

Initially, basin and climatic characteristics from the final regional regression equations (table 7) were used to define an ROI and explanatory variables. The entire database, which consisted of 333 gaged sites, was used to determine the unique subset of gaged sites. Combinations of the seven variables were tested to determine the number $(\mathrm{N})$ of gaged sites and the number and identity of the basin and climatic characteristics of $d_{i j}$ and explanatory variables in the ROI. Each set of variables was tested using values of $\mathrm{N}$ starting at 20 and increasing by 5 until 100 sites were used. Initial testing indicated that RMSEs increased significantly when DA was used singly or in combination with other variables for $\mathrm{d}_{\mathrm{ij}}$. As a result, DA was used only as an explanatory variable in subsequent testing.

The best combination of variables to define the ROI was forest cover and slopes greater than 30 percent, and the optimal value for $\mathrm{N}$ was 40 . The best combination of explanatory variables defined by the GLS regression part of the analysis was drainage area, mean basin elevation, mean annual precipitation, and forest cover.

The average RMSE was calculated for the ROI method (table 8) and ranged from 55.5 percent for a 5year recurrence interval to 72.4 percent for a 500-year recurrence interval. Also, the average RMSE was calculated for the regional regression equations (table 7) for each region and recurrence interval and is shown in table 8. On the basis of RMSE comparisons (table 8) between the ROI method and the regional regression equations, the regional regression equations produced better overall results (smaller RMSEs) for regions 1 through $7 \mathrm{a}$. For parts of regions $7 \mathrm{~b}$ and 8 , the ROI method produced slightly better results than did the regional regression equations only in the lower frequency intervals. For most regions, the differences between the two methods were greater than 10 percent and, for region 5, were greater than 20 percent.

In an effort to obtain smaller RMSE values than the regional regression equations produced, regions were combined to form several sets of larger regions. In other ROI studies (Pope and Tasker, 1990; Tasker and Slade, 1994; Hodge and Tasker, 1995), the ROI method was applied to several large regions (containing at least 100 gaged sites) within the respective State. In this study, regions 1, 2, and 3 were combined to form the first set; regions 4 and 5 were combined to form the second set; and regions $6,7 \mathrm{a}, 7 \mathrm{~b}$, and 8 were combined to form the third set. Then the ROI method was applied to each of the three combined regions. Combining regions did not result in smaller RMSE values than when all 333 gaged sites in the database were used. Regions were subsequently recombined and retested but, again, no smaller RMSE values resulted than when all gages were used. Therefore, the ROI method is not recommended and should not be used for determining flood-frequency estimates for ungaged sites on unregulated and undiverted streams in Idaho because the results, overall, are less accurate and the calculations are more complex than those of regional regression equations. 
Table 8. Average root-mean-squared errors, in percent, for region-of-influence and regional regression methods for selected recurrence intervals

\begin{tabular}{|c|c|c|c|c|c|c|c|c|c|c|}
\hline \multirow{3}{*}{$\begin{array}{c}\text { Recurrence } \\
\text { interval }\end{array}$} & \multicolumn{10}{|c|}{ Average root-mean-squared error, in percent } \\
\hline & \multirow{2}{*}{$\begin{array}{c}\text { Region-of- } \\
\text { influence } \\
\text { method }\end{array}$} & \multicolumn{9}{|c|}{ Regional regression method } \\
\hline & & Region 1 & Region 2 & Region 3 & Region 4 & Region 5 & Region 6 & Region 7a & Region $7 b$ & Region 8 \\
\hline 2 & 60.2 & 63.1 & 52.8 & 68.8 & 66.8 & 39.8 & 61.7 & 65.9 & 109 & 69.2 \\
\hline 5 & 55.5 & 50.5 & 52.9 & 48.7 & 56.4 & 38.3 & 56.2 & 54.6 & 81.2 & 64.1 \\
\hline 10 & 55.9 & 47.4 & 53.9 & 43.6 & 52.4 & 38.5 & 55.5 & 51.3 & 69.2 & 63.0 \\
\hline 25 & 58.3 & 47.5 & 56.2 & 42.5 & 49.4 & 39.2 & 56.3 & 50.2 & 59.5 & 62.9 \\
\hline 50 & 60.9 & 49.8 & 58.0 & 43.7 & 48.1 & 40.0 & 57.2 & 50.7 & 55.6 & 63.4 \\
\hline 100 & 64.0 & 53.3 & 60.0 & 46.1 & 47.4 & 41.1 & 58.4 & 52.2 & 54.2 & 64.2 \\
\hline 200 & 67.4 & 57.6 & 62.2 & 49.3 & 47.2 & 42.1 & 59.7 & 54.3 & 54.8 & 65.1 \\
\hline 500 & 72.4 & 64.3 & 65.2 & 54.3 & 47.4 & 43.7 & 61.8 & 57.8 & 58.3 & 66.5 \\
\hline
\end{tabular}

\section{LIMITATIONS OF REGIONAL REGRESSION EOUATIONS}

The average standard errors of prediction given in table 7 represent the general measure of how well the regional regression equations will estimate peak flows when they are applied to ungaged sites. The accuracy of the equations will be reduced if the values of explanatory variables are outside the range of the values used to develop the equations. The magnitude of this reduction in accuracy is unknown. Standard errors of prediction vary from site to site, depending on the values of the explanatory variables for each site. The standard errors of prediction will be smaller for sites where values of the explanatory variables are near the mean of their range. If the value of an explanatory variable used in the regression equations is near its extreme (maximum or minimum, table 4), the equations might result in unreliable and erroneous estimates. For example, figure 4 shows a "cloud of common values" for the two explanatory variables used in regression equations for region 3 . If the maximum value for drainage area and the minimum value for mean basin elevation were used, this combination would plot outside the cloud of common values and, thus, the equations might result in unreliable estimates.

Generating basin characteristic values using datasets or algorithms other than those described in this study also will result in estimates of unknown reliability. The standard errors for each equation are applica- ble only if the datasets presented in table 2 and methods described in table 3 are used to obtain the required basin characteristics; however, GIS programs other than Arc/Info can be used to measure and calculate the basin characteristics.

The regression equations are not applicable for streams that exhibit significant gains and (or) losses as a result of flow from springs or seepage through highly permeable streambeds. The equations also are not applicable for streams affected by irrigation diversions or large dams that regulate streamflow. The Boise River downstream from Lucky Peak Lake, the Clearwater River downstream from Dworshak Reservoir, and the entire Snake River in Idaho are examples of stream

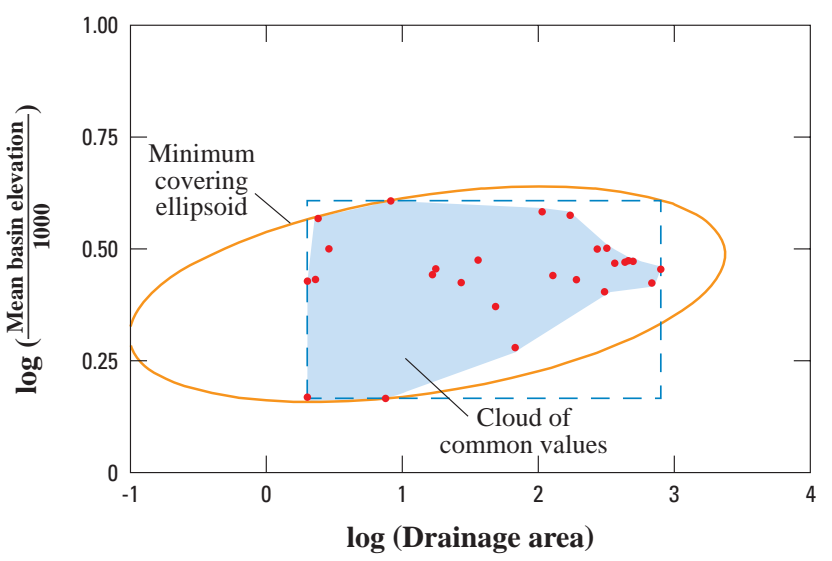

Figure 4. Joint distribution of drainage area and mean basin elevation, and minimum covering ellipsoid for gaged sites in region 3, Idaho 
reaches within the study area for which the regional regression equations are not applicable.

The regional regression equations might not be reliable for sites in urbanized basins. Techniques for estimating peak flows for urban streams are presented in a report by Sauer and others (1983).

In general, the equations are more reliable (smaller standard errors of estimate) for estimating the middle peak-flow frequencies $(10,25$, and 50 years) than for estimating the high peak-flow frequencies $(100,200$, and 500 years) and the low peak-flow frequencies ( 2 and 5 years). This finding is consistent with findings in many other regional regression studies.

\section{APPLICATION OF METHODS}

For gaged sites, the magnitude of peak flows at selected recurrence intervals can be calculated using the procedures for log-Pearson Type III distribution described in the section "Methods of Estimating Peak Flows for Gaged Sites" and procedures described in Bulletin 17B (Interagency Advisory Committee on Water Data, 1982).

For ungaged sites near gaged sites on the same stream, the magnitude of peak flows can be calculated using the drainage-area ratio, also described in the section "Methods for Estimating Peak Flows for Gaged Sites," and summarized as follows: First, the site is located on a map and the hydrologic region in which the site is located is identified. Next, the drainage boundaries of the site are delineated and the drainage area contained within those boundaries is measured using GIS software. With this information, peak flows can be calculated using equation (2), presented on p. 12. If the ungaged site lies between two gaged sites, peak flows can be calculated using equation (3), presented on p. 13.

If the ungaged site is not near a gaged site, then regional regression equations (table 7) are used to calculate peak flows. Basin and climatic characteristics used in all methods are determined using the datasets described in table 2 and methods described in table 3.

In the subsequent paragraphs, specific examples are given for calculating peak flows. The first example addresses the situation where an ungaged site is relatively near a gaged site on the same stream. The second example addresses the situation where regression equations are needed to calculate peak flows for a specific site. The third example addresses the same situation as the second example, except that the drainage area of the specified site encompasses parts of two separate regions.

\section{Example 1}

A 100-year peak-flow $\left(\mathrm{Q}_{100}\right)$ estimate for an ungaged site located upstream from a gaged site on the same stream in region 4 is needed. The 100 -year peak flow at the gage is $7,010 \mathrm{ft}^{3} / \mathrm{s}$. The drainage-area ratio method (equation 2) is used to estimate $\mathrm{Q}_{100}$ for the ungaged site. The drainage area (DA) is $428 \mathrm{mi}^{2}$ for the gaged site and $351 \mathrm{mi}^{2}$ for the ungaged site. DA for both sites is determined using a GIS and the datasets in table 2. The value for exponent $a$ is 0.85 (table 6) for region 4 . The drainage-area ratio $\left(\mathrm{DA}_{\mathrm{u}} / \mathrm{DA}_{\mathrm{g}}\right)$ is 0.82 , which is between the guideline of 0.5 and 15 .

$$
\mathrm{Q}_{\mathrm{u}}=\left(\frac{\mathrm{DA}_{\mathrm{u}}}{\mathrm{DA}_{\mathrm{g}}}\right)^{a} \mathrm{Q}_{\mathrm{g}}
$$

$$
\begin{aligned}
\mathrm{Q}_{100} & =\left(\frac{351}{428}\right)^{0.85} 7,010 \\
\mathrm{Q}_{100} & =5,920 \mathrm{ft}^{3} / \mathrm{s}
\end{aligned}
$$

Final values are rounded to three significant figures.

\section{Example 2}

A 100-year peak-flow estimate for an ungaged site in region 5 is needed. The required basin characteristics for region 5 regional regression equations were determined to be the following: DA, $480.5 \mathrm{mi}^{2}$; $\mathrm{P}$, 28.33 in.; and NF30, 21.5 percent. Then

$$
\begin{aligned}
& \mathrm{Q}_{100}=0.620 \mathrm{DA}^{0.926} \mathrm{P}^{1.52}(\mathrm{NF} 30+1)^{-0.499} \\
& \mathrm{Q}_{100}=0.620(480.5)^{0.926} 28.33^{1.52}(21.5+1)^{-0.499} \\
& \mathrm{Q}_{100}=6,430 \mathrm{ft}^{3} / \mathrm{s}
\end{aligned}
$$

Final values are rounded to three significant figures.

On the basis of the range of the average standard errors of prediction given in table 7, about 67 percent of all estimates at this site will be between 4,340 and $9,540 \mathrm{ft}^{3} / \mathrm{s}$ ( -32.6 to +48.4 percent). Put another way, 
there is about a 67-percent certainty that the "true" value of $\mathrm{Q}_{\mathrm{T}}$ is between 4,340 and 9,540 $\mathrm{ft}^{3} / \mathrm{s}$. Instead of calculating these equations (table 7) manually, a computer program for the regional regression equations, presented in the section titled "Computer Program for Regional Regression Equations," can be used. This computer program also calculates the error of prediction and the 90-percent confidence interval for individual estimates for each recurrence interval and for each region.

\section{Example 3}

A 100-year peak-flow estimate is needed for an ungaged stream in region 4 with a drainage basin encompassing parts of regions 4 and 5 . The procedure is similar to that given in example 2, except the regional regression equations would be solved for each of the associated regions and the results would be averaged or apportioned according to the fraction of the contributing drainage area that is in each region (Sando, 1998). The required basin characteristics for region 4 and 5 equations were determined to be the following: DA, $853.0 \mathrm{mi}^{2}$; P, 35.4 in.; E, 5,125.6 ft; and NF30, 24.6 percent. The part of the drainage area in region 4 is $622.0 \mathrm{mi}^{2}$ and the part in region 5 is $231.0 \mathrm{mi}^{2}$.

\section{Region 4 equations}

$$
\begin{aligned}
& \mathrm{Q}_{100}=273 \mathrm{DA}^{0.837}(\mathrm{E} / 1,000)^{-1.01} \\
& \mathrm{Q}_{100}=273(853.0)^{0.837}(5,125.6 / 1,000)^{-1.01} \\
& \mathrm{Q}_{100}=14,877 \mathrm{ft}^{3} / \mathrm{s}
\end{aligned}
$$$$
\text { Region } 5 \text { equations }
$$$$
\mathrm{Q}_{100}=0.620 \mathrm{DA}^{0.926} \mathrm{P}^{1.52}(\mathrm{NF} 30+1)^{-0.499}
$$$$
\mathrm{Q}_{100}=0.620(853.0)^{0.926}+(35.4)^{1.52}(24.6)^{-0.499}
$$$$
\mathrm{Q}_{100}=14,395 \mathrm{ft}^{3} / \mathrm{s}
$$

\section{Area-weighted average of the 100-year peak flows}

$$
\begin{aligned}
\mathrm{Q}_{\mathrm{u}}=\mathrm{Q}_{\mathrm{g}_{1}}\left(\frac{\mathrm{DA}_{\mathrm{g}_{1}}}{\mathrm{DA}}\right)+\mathrm{Q}_{\mathrm{g}_{2}}\left(\frac{\mathrm{DA}_{\mathrm{g}_{2}}}{\mathrm{DA}}\right) \\
\mathrm{Q}_{100}=14,877(622.0 / 853.0)+14,395(231.0 / 853.0) \\
\mathrm{Q}_{100}=14,700 \mathrm{ft}^{3} / \mathrm{s}
\end{aligned}
$$

Final values are rounded to three significant figures.

The computer program "Regional Regression Program" also can be used to estimate the peak-flow values in this example. The regional regression equation computer program would be executed twice, once for region 4 and once for region 5. Then the average value would be estimated by weighting according to drainage area (area-weighted average) as shown in equation 8 .

\section{COMPUTER PROGRAM FOR REGIONAL REGRESSION EQUATIONS}

As part of the study described in this report, a computer program was adapted to calculate peak flows using regional regression equations (table 7). The program also calculates the associated site-specific errors of prediction for ungaged sites.

The computer software package includes an executable program file and other supporting files. The software package and instructions for downloading, installing, and executing the program are available from the Idaho District home page on the World Wide Web at URL http://idaho.usgs.gov/PDF/wri024170/program.html The executable program idregeq.exe will calculate peak flows for the regional regression equations (table 7). This program must be executed in a disk operating system (DOS) and the user will be prompted to input data for ungaged sites.

The regional regression equations can be calculated manually, but the program allows more convenient and efficient calculation of the errors of prediction. The errors of prediction for ungaged sites are calculated by matrix algebra using the weighted matrix $\left(\mathrm{X}^{\mathrm{T}} \Lambda^{-1} \mathrm{X}\right)^{-1}$ obtained from GLS analysis. Further explanation for computing the error of prediction is given in a report by Hodgkins (1999), and the $\left(X^{\mathrm{T}} \Lambda^{-1} X\right)^{-1}$ matrices for each recurrence interval and region are shown in table 9. 
To execute the regional regression program, enter the program's name (idregeq.exe) in a DOS window. The program will ask for the name of an output file to save program results, an identifier (name and (or) number) of the ungaged site, the region number where the ungaged site is located, and the value for each explanatory variable used in the region's regional regression equations. Results will be displayed on the screen, and all program results will be saved in a single output file no matter how many times the program repeats. A computer session for example 2 is shown in figure 5, and the bold letters and (or) numbers are entries specified by the user and needed by the program. Figure 5 also shows calculated peak flows, site-specific standard errors of prediction (SE) and the 90-percent confidence intervals for the estimates. A confidence interval gives the level of confidence about an upper and lower limit. For example 2 (fig. 5), the 100-year peak flow is 6,430 $\mathrm{ft}^{3} / \mathrm{s}$, and errors of prediction range from -31.7 percent to +46.5 percent. There is a 90 -percent confidence level that the predicted value for the 100-year peak flow is between $3,380 \mathrm{ft}^{3} / \mathrm{s}$ and $12,200 \mathrm{ft}^{3} / \mathrm{s}$. If input data for explanatory variables are outside the minimum and maximum values (for example, the dashed-line box in figure 4), the program will print a warning that the specific explanatory variable is beyond the observed data.

Caution should be used when extrapolating beyond the area of the original sample data (cloud of common values) (fig. 4) when estimating peak flows from a regression model. In regression, extrapolation occurs when at least one of the predictors is outside the range of sample data. In multiple regression, it is possible for the explanatory variables to be within the minimum and maximum values and still be considered an extrapolation. For example (fig. 4), a log (Drainage area) of 2.7 and $\log$ (Mean basin elevation/1,000) of 0.21 are within the minimum and maximum values of both variables, but these values are considered extrapolations because the sample data do not contain similar combinations of variables. To define the area of interpolation or extrapolation in multiple regression, a minimum covering ellipsoid (MCE) is used because it can be expressed in mathematical form, whereas the area represented by the cloud of common values in figure 4 cannot. For two explanatory variables in a regression equation, a graph similar to figure 4 can be produced and the joint distribution can be easily seen. But for three or more explanatory variables in a regression equation, the area represented by the cloud of common values would be more difficult, if not impossible, to distinguish. To determine whether the combination of explanatory variables in an interpolation or an extrapolation, MCE calculations are included in the computer program. The program prints a warning only if the combination of explanatory variables is greater than the MCE. For more information concerning the MCE, refer to the report by Weisberg (1990). For example 2, the three explanatory variables resulted in no warning statements; thus, input data were interpolated.

\section{SUMMARY}

Accurate and reliable estimates of the magnitude and frequency of floods are critical for such activities as bridge design, flood-plain delineation and management, water-supply management, and management of water-control structures, among others. Recognizing the need for accurate estimates of flood frequency for ungaged, unregulated, and undiverted streams in Idaho, the U.S. Geological Survey, in cooperation with the Idaho Department of Transportation, Idaho Bureau of Disaster Services, and the U.S. Army Corps of Engineers, conducted a study to further define the relation between peak flows at selected recurrence intervals and selected physical and climatic characteristics. This study documents the development of methods for estimating peak flows for gaged and ungaged sites. For gaged sites, peak flows can be obtained from tables in this report or calculated by using the log-Pearson Type III distribution and following the guidelines and calculation methods described in Bulletin 17B. If the ungaged site is on a gaged stream, then peak flows can be estimated by the drainage-area ratio method that relates the drainage area for the ungaged site to the drainage area for the gaged site.

Two methods also were developed for regionalizing, or extending in space, flood-frequency estimates for gaged sites. In the first method, traditional regional regression analysis, a generalized least-squares regression was used to develop a set of predictive equations for each of the eight hydrologic regions in Idaho. In the second method, the region-of-influence method, peakflow estimates for ungaged sites were predicted interactively on the basis of data from a subset of gaged sites with basin and climatic characteristics similar to those of the ungaged sites.

Flow records from an initial set containing more than 500 gaged sites were examined. Sites that did not 
Figure 5. Input session of example 2 for the regional regression program (idregeq.exe). Bolded letters and numbers are input by the user.

[RI, recurrence interval in years; cfs, cubic feet per second; DA, drainage area in square miles; P, mean annual precipitation in inches; NF30, north-facing slopes greater than 30 percent in percent; C:l>, DOS command prompt]

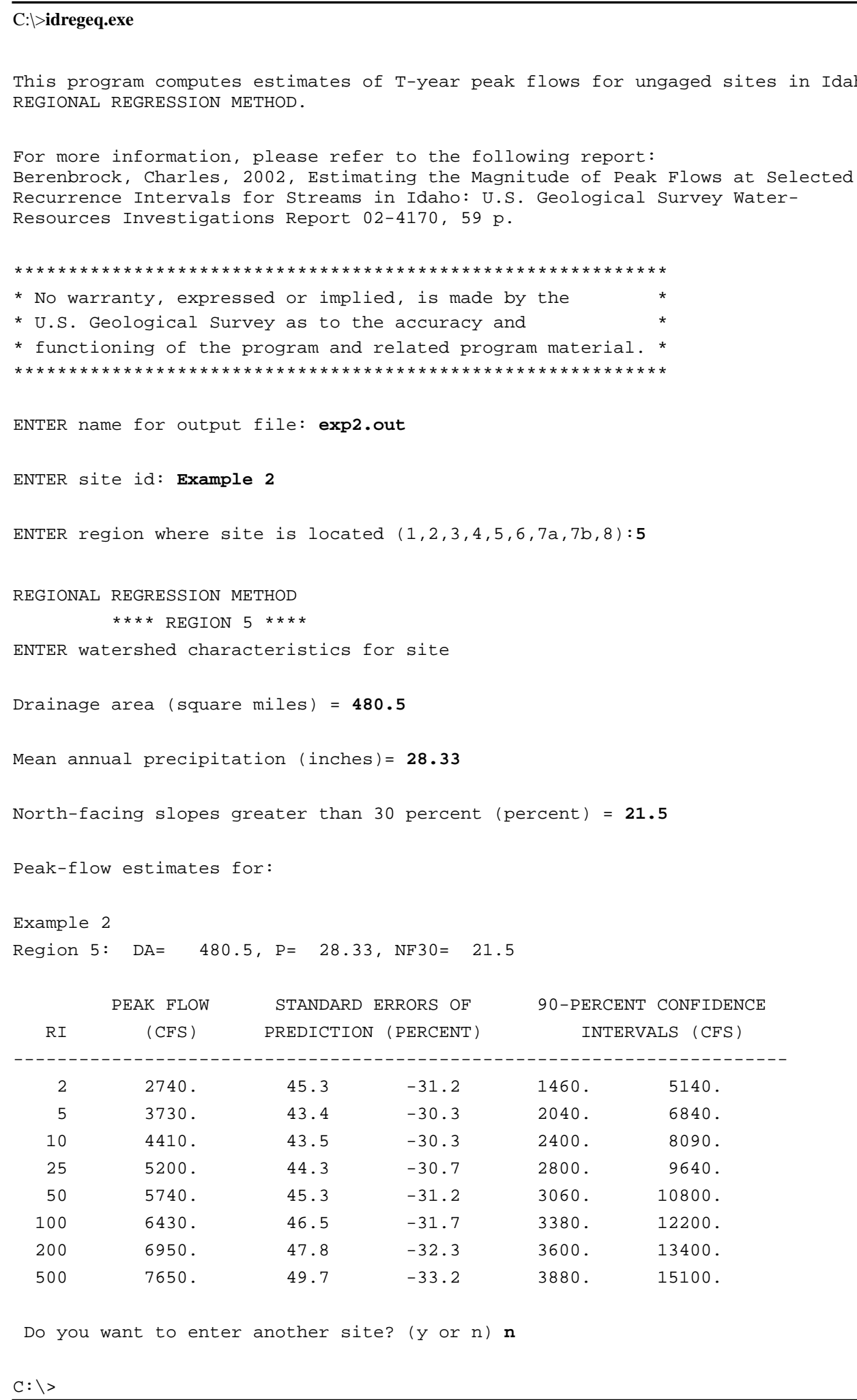

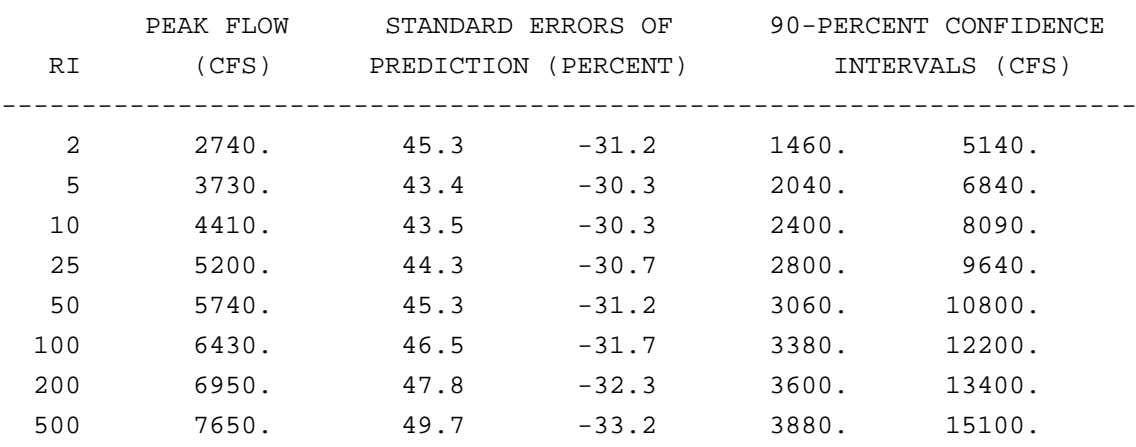


have 10 or more years of record and sites affected by regulation or diversions were excluded from further analysis. The remaining 333 sites formed the database for the two regionalization methods. Peak-flow data and basin and climatic characteristics data (explanatory variables) were compiled and calculated for sites in the database by using a geographic information system. These data also were included in the database. Preliminary multiple-regression analyses, using ordinary leastsquares regression, were conducted to identify the best combination of explanatory variables for inclusion in the generalized least-squares analysis.

Generalized least-squares analysis was used to develop a set of equations for each region that relate the 2-, 5-, 10-, 25-, 50-, 100-, 200-, and 500-year recurrence interval peak flows to basin and climatic characteristics. Regression equations for region $7 \mathrm{~b}$ included only one explanatory variable; equations for regions 1 , 5 , and 8 included the most explanatory variables (three). All regional regression equations required drainage area as an input variable. Three of the explanatory variables - north-facing slopes greater than 30 percent, basin slope, and slopes greater than 30 percent-have not been used previously in regional regression equations for estimating peak flows in Idaho. Model standard errors and standard errors of prediction also were calculated for each equation. The average standard error of prediction ranged from +143 to -34.2 percent. The range of errors was narrowest $(-34.2$ to +51.9 ) for region 5. Usually, errors were smaller and the range of errors was narrower for the middle recurrence intervals $(10,25$, and 50 years) than for the lower and upper recurrence intervals $(2,5,200$, and 500 years).

The region-of-influence method also was adapted to the peak-flow and basin and climatic characteristics data for Idaho. The drainage area, mean basin elevation, mean annual precipitation, and forest cover were required to predict the 2-, 5-, 10-, 25-, 50-, 100-, 200-, and 500-year recurrence interval peak flows for a specified ungaged site. All 333 gaged sites in the database were used to determine the region of influence. The average root-mean-squared error for the region-ofinfluence method ranged from 55.5 percent to 72.4 percent. The RMSEs were generally larger for the ROI method, averaging greater than 10 percent for regions 1 through 7a. In region 5, the RMSEs were generally greater than 20 percent. In region 8, the RMSEs were generally smaller for the region-of-influence method than for the regional regression equations, and for region 7b, the RMSEs were smaller only for the 2-, 5-, $10-$, and 25-year recurrence interval peak flows. Therefore, the region-of-influence method is not recommended for use in determining flood-frequency estimates for ungaged sites in Idaho because the results are less accurate and the calculations are more complex than those of regional regression equations. The regional regression equations are considered to be the primary method of estimating the magnitude and frequency of peak flows for ungaged sites on undiverted and unregulated streams in Idaho.

A computer program (idregeq.exe) automates the calculations required for the regional regression equations, site-specific errors of prediction, and the 90-percent confidence intervals.

\section{REFERENCES CITED}

Acreman, M.C., and Wiltshire, S.E., 1987, Identification of regions for regional flood frequency analysis [abs.]: EOS, v. 68, no. 44.

Aitchison, M.C., and Brown, J.A.C., 1957, The lognormal distribution: Cambridge University Press, $176 \mathrm{p}$.

Burn, D.H., 1990a, An appraisal of the "region of influence" approach to flood frequency analysis: Hydrological Sciences Journal, v. 35, no. 24, p. 149-65.

1990b, Evaluation of regional flood frequency analysis with a region of influence approach: Water Resources Research, v. 26, no. 10, p. 2257-2265.

Environmental Systems Research Institute, Inc., 1999, Getting started with Arc/Info: Redlands, Calif., Environmental Systems Research Institute, Inc., $230 \mathrm{p}$.

Haan, C.T., 1977, Statistical methods in hydrology: Ames, Iowa State University Press, 378 p.

Harenberg, W.A., 1980, Using channel geometry to estimate flood flows at ungaged sites in Idaho: U.S. Geological Survey Water-Resources Investigations 80-32, $39 \mathrm{p}$.

Hedman, E.R., and Osterkamp, W.R., 1982, Streamflow characteristics related to channel geometry of streams in Western United States: U.S. Geological Survey Water-Supply Paper 2193, 17 p.

Helsel, D.R., and Hirsch, R.M., 1992, Statistical methods in water resources: New York, Studies in 
Environmental Science 49, Elsevier Science, $522 \mathrm{p}$.

Hodge, S.A., and Tasker, G.D., 1995, Magnitude and frequency of floods in Arkansas: U.S. Geological Survey Water-Resources Investigations Report 95-4224, 52 p., 1 diskette.

Hodgkins, Glenn, 1999, Estimating the magnitude of peak flows for streams in Maine for selected recurrence intervals: U.S. Geological Survey Water-Resources Investigations Report 99-4008, $45 \mathrm{p}$.

Hortness, J.E., and Berenbrock, Charles, 2001, Estimating monthly and annual streamflow statistics at ungaged sites in Idaho: U.S. Geological Survey Water-Resources Investigations Report 01-4093, $36 \mathrm{p}$.

Interagency Advisory Committee on Water Data, 1982, Guidelines for determining flood flow frequency, Bulletin 17B of the Hydrology Subcommittee: Reston, Va., U.S. Geological Survey, Office of Water Data Coordination, [183 p.]

Kjelstrom, L.C., 1995, Methods to estimate annual mean spring discharge to the Snake River between Milner Dam and King Hill, Idaho: U.S. Geological Survey Water-Resources Investigations Report 95-4055, 9 p.

Kjelstrom, L.C., and Moffatt, R.L., 1981, A method of estimating flood-frequency parameters for streams in Idaho: U.S. Geological Survey Open-File Report 81-909, 99 p.

Molnau, M., 1995, Mean annual precipitation, 19611990, Idaho: Moscow, University of Idaho, Agricultural Engineering Department, State Climate Program, scale 1:1,000,000. Also available at URL http://snow.ag.uidaho.edu/Climate/reports.html

Pope, B.F., and Tasker, G.D., 1999, Estimating the magnitude and frequency of floods in rural basins of North Carolina: U.S. Geological Survey WaterResources Investigations Report 99-4114, 44 p.
Quillian, E.W., and Harenberg, W.A., 1982, An evaluation of Idaho stream-gaging networks: U.S. Geological Survey Open-File Report 82-865, 57 p.

Riggs, H.C., 1972, Low-flow investigations: U.S. Geological Survey Techniques of Water-Resources Investigations, Book 4, Chap. B1, 18 p.

Sando, S.K., 1998, Techniques for estimating peakflow magnitude and frequency relations for South Dakota streams: U.S. Geological Survey WaterResources Investigations Report 98-4055, 48 p.

Sauer, V.B., Thomas, W.O., Jr., Stricker, V.A., and Wilson, K.V., 1983, Flood characteristics of urban watersheds in the United States: U.S. Geological Survey Water-Supply Paper 2207, 63 p.

Stedinger, J.R., and Tasker, G.D., 1985, Regional hydrologic analysis 1 -ordinary, weighted, and generalized least squares compared: American Geophysical Union, Water Resources Research, v. 21, no. 9, p. 1421-1432.

Tasker, G.D., and Slade, R.M., Jr., 1994, An interactive regional regression approach to estimating flood quantiles, in Fontane, D.G., and Tuvel, H.N., Water Policy and Management-Solving the Problems, Proceedings of the 21st Annual Conference of the Water Resources Planning and Management Division: American Society of Civil Engineers, p. 782-785.

Tasker, G.D., and Stedinger, J.R., 1989, An operational GLS model for hydrologic regression: Journal of Hydrology, v. 111, p. 361-375.

Thomas, B.E., Hjalmarson, H.W., and Waltemeyer, S.D., 1994, Methods for estimating magnitude and frequency of floods in the Southwestern United States: U.S. Geological Survey Open-File Report 93-419, $211 \mathrm{p}$.

Thomas, C.A., Harenberg, W.A., and Anderson, J.M., 1973, Magnitude and frequency of floods in small drainage basins in Idaho: U.S. Geological Survey Water-Resources Investigations 7-73, $61 \mathrm{p}$.

Weisberg, Sanford, 1990, Applied linear regression, 2d ed.: New York, John Wiley and Sons, 344 p. 
Tables 4, 5, and 9 
Table 4. Basin and climatic characteristics for streamflow-gaging stations in Idaho and bordering States used in regional regression analysis

[DA, drainage area; E, mean basin elevation; F, percentage of forest cover in the basin; P, mean annual precipitation; BS, average basin slope; NF30, percentage of north-facing slopes greater than 30 percent; S30, percentage of slopes greater than 30 percent; mi², square miles; ft, feet; in., inches; ft/mi, feet per mile; ID, Idaho; MT, Montana; NV, Nevada; OR, Oregon; WA, Washington; WY, Wyoming; Y.N.P., Yellowstone National Park]

\begin{tabular}{|c|c|c|c|c|c|c|c|c|c|}
\hline $\begin{array}{l}\text { Map } \\
\text { No. }\end{array}$ & $\begin{array}{c}\text { Gaging } \\
\text { station No. }\end{array}$ & Gaging station name & $\begin{array}{c}\text { DA } \\
\left(\mathrm{mi}^{2}\right)\end{array}$ & $\begin{array}{c}E \\
(\mathrm{ft})\end{array}$ & $\begin{array}{c}\mathbf{F} \\
\text { (percent) }\end{array}$ & $\begin{array}{c}P \\
\text { (in.) }\end{array}$ & $\begin{array}{c}\text { BS } \\
\text { (percent) }\end{array}$ & $\begin{array}{c}\text { NF30 } \\
\text { (percent) }\end{array}$ & $\begin{array}{c}\mathrm{S} 30 \\
\text { (percent) }\end{array}$ \\
\hline & & \multicolumn{8}{|c|}{ REGION 1} \\
\hline 1 & 12305500 & Boulder Creek near Leonia, ID & 55.3 & $4,686.9$ & 92.0 & 48.30 & 37.1 & 21.8 & 69.4 \\
\hline 2 & 12309000 & Cow Creek near Bonners Ferry, ID & 17.6 & $3,189.5$ & 77.1 & 30.05 & 26.7 & 28.8 & 40.8 \\
\hline 3 & 12310800 & Trail Creek at Naples, ID & 16.0 & $3,498.6$ & 92.6 & 31.27 & 24.3 & 13.7 & 27.8 \\
\hline 4 & 12311000 & Deep Creek at Moravia, ID & 133.1 & $3,257.0$ & 72.6 & 30.36 & 21.2 & 9.7 & 27.0 \\
\hline 5 & 12313500 & Ball Creek near Bonners Ferry, ID & 26.6 & $5,194.4$ & 78.7 & 42.20 & 40.6 & 18.3 & 70.2 \\
\hline 6 & 12316800 & Mission Creek near Copeland, ID & 12.5 & $4,084.4$ & 94.5 & 29.15 & 25.4 & 5.8 & 33.2 \\
\hline 7 & 12320500 & Long Canyon Creek near Porthill, ID & 29.9 & $5,347.3$ & 89.5 & 41.32 & 46.4 & 22.7 & 81.4 \\
\hline 8 & 12321000 & Smith Creek near Porthill, ID & 71.1 & $5,054.2$ & 70.4 & 46.14 & 37.0 & 19.8 & 62.3 \\
\hline 9 & 12392100 & Trapper Creek near Clark Fork, ID & 1.1 & $4,844.3$ & 96.1 & 57.78 & 50.2 & 9.1 & 91.6 \\
\hline 10 & 12392155 & Lightning Creek at Clark Fork, ID & 115.1 & $4,648.5$ & 82.4 & 54.32 & 43.2 & 20.3 & 71.8 \\
\hline 11 & 12392300 & Pack River near Colburn, ID & 121.4 & $4,280.6$ & 62.6 & 38.15 & 32.2 & 15.9 & 52.4 \\
\hline 12 & 12392800 & Hornby Creek near Dover, ID & 3.1 & $2,519.6$ & 89.4 & 30.00 & 17.9 & 3.7 & 11.9 \\
\hline 13 & 12393500 & Priest River at outlet of Priest Lake near Coolin, ID & 596.6 & $3,941.3$ & 79.0 & 38.79 & 28.9 & 13.7 & 46.3 \\
\hline 14 & 12393600 & Binarch Creek near Coolin, ID & 10.6 & $3,258.6$ & 97.6 & 30.58 & 35.0 & 16.6 & 59.3 \\
\hline 15 & 12396000 & Calispell Creek near Dalkena, WA & 68.2 & $3,622.5$ & 79.6 & 36.71 & 30.1 & 20.0 & 51.8 \\
\hline 16 & 12408500 & Mill Creek near Colville, WA & 82.5 & $3,520.8$ & 89.4 & 37.74 & 29.6 & 13.9 & 46.2 \\
\hline 17 & 12409000 & Colville River at Kettle Falls, WA & $1,011.0$ & $2,904.3$ & 77.0 & 27.57 & 22.3 & 9.0 & 28.2 \\
\hline 18 & 12427000 & Little Spokane River at Elk, WA & 84.4 & $2,459.0$ & 65.2 & 28.22 & 13.2 & 4.1 & 10.4 \\
\hline 19 & 12429600 & Deer Creek near Chattaroy, WA & 31.0 & $2,683.7$ & 65.3 & 27.61 & 15.3 & 4.4 & 9.0 \\
\hline 20 & 12430370 & Bigelow Gulch near Spokane, WA & 4.4 & $2,245.2$ & 23.9 & 19.37 & 9.7 & 0.6 & 2.6 \\
\hline \multirow[t]{2}{*}{21} & 12431000 & Little Spokane River at Dartford, WA & 634.9 & $2,397.7$ & 54.6 & 25.11 & 12.2 & 2.8 & 9.4 \\
\hline & & \multicolumn{8}{|c|}{ REGION 2} \\
\hline 22 & 12302500 & Granite Creek near Libby, MT & 23.7 & $5,275.3$ & 66.4 & 52.96 & 54.1 & 26.7 & 82.4 \\
\hline 23 & 12303100 & Flower Creek near Libby, MT & 11.3 & $5,466.8$ & 76.7 & 52.64 & 48.3 & 30.0 & 71.2 \\
\hline 24 & 12303500 & Lake Creek at Troy, MT & 125.0 & $4,069.2$ & 87.3 & 43.94 & 38.5 & 21.0 & 62.8 \\
\hline 25 & 12304250 & Whitetail Creek near Yaak, MT & 2.4 & $4,299.5$ & 81.5 & 31.61 & 27.4 & 0.5 & 37.2 \\
\hline 26 & 12304300 & Cyclone Creek near Yaak, MT & 5.7 & $4,627.2$ & 96.9 & 40.99 & 33.9 & 30.1 & 63.5 \\
\hline 27 & 12304400 & Fourth of July Creek near Yaak, MT & 7.8 & $4,468.8$ & 96.7 & 38.86 & 35.9 & 26.7 & 72.6 \\
\hline 28 & 12341000 & Rattlesnake Creek at Missoula, MT & 79.9 & $5,708.4$ & 79.3 & 37.04 & 36.9 & 16.7 & 57.6 \\
\hline 29 & 12345800 & Camas Creek near Hamilton, MT & 5.1 & $7,064.0$ & 51.8 & 50.32 & 42.5 & 19.5 & 73.4 \\
\hline 30 & 12347500 & Blodgett Creek near Corvallis, MT & 26.1 & $6,649.7$ & 50.4 & 60.87 & 57.0 & 32.1 & 82.8 \\
\hline 31 & 12350200 & Gash Creek near Victor, MT & 3.3 & $6,684.3$ & 73.4 & 54.70 & 37.9 & 22.0 & 69.2 \\
\hline
\end{tabular}


Table 4. Basin and climatic characteristics for streamflow-gaging stations in Idaho and bordering States used in regional regression analysis--Continued

\begin{tabular}{|c|c|c|c|c|c|c|c|c|c|}
\hline $\begin{array}{l}\text { Map } \\
\text { No. }\end{array}$ & $\begin{array}{c}\text { Gaging } \\
\text { station No. }\end{array}$ & Gaging station name & $\begin{array}{c}\text { DA } \\
\left(\mathrm{mi}^{2}\right)\end{array}$ & $\begin{array}{c}E \\
(\mathrm{ft})\end{array}$ & $\begin{array}{c}\mathbf{F} \\
\text { (percent) }\end{array}$ & $\begin{array}{c}P \\
\text { (in.) } \\
\end{array}$ & $\begin{array}{c}\text { BS } \\
\text { (percent) }\end{array}$ & $\begin{array}{c}\text { NF30 } \\
\text { (percent) }\end{array}$ & $\begin{array}{c}\mathrm{S} 30 \\
\text { (percent) }\end{array}$ \\
\hline & & \multicolumn{8}{|c|}{ REGION 2 -- Continued } \\
\hline 32 & 12350500 & Kootenai Creek near Stevensville, MT & 29.0 & $6,557.7$ & 60.4 & 55.58 & 58.8 & 28.8 & 89.6 \\
\hline 33 & 12352000 & Lolo Creek above Sleeman Creek, near Lolo, MT & 249.2 & $5,272.8$ & 84.7 & 46.82 & 35.3 & 19.1 & 58.9 \\
\hline 34 & 12353800 & Thompson Creek near Superior, MT & 12.0 & $4,648.3$ & 88.2 & 39.04 & 41.2 & 27.3 & 76.2 \\
\hline 35 & 12353850 & East Fork Timber Creek near Haugan, MT & 2.6 & $4,669.2$ & 96.0 & 48.34 & 32.8 & 1.6 & 54.3 \\
\hline 36 & 12354000 & St. Regis River near St. Regis, MT & 43.6 & $4,843.4$ & 88.3 & 44.49 & 47.2 & 30.4 & 84.6 \\
\hline 37 & 12354100 & North Fork Little Joe Creek near St. Regis, MT & 14.4 & $4,854.3$ & 89.8 & 42.42 & 45.6 & 28.5 & 83.1 \\
\hline 38 & 12389500 & Thompson River near Thompson Falls, MT & 641.5 & $4,567.1$ & 85.8 & 29.56 & 30.0 & 15.9 & 47.0 \\
\hline 39 & 12390700 & Prospect Creek at Thompson Falls, MT & 181.5 & $4,437.3$ & 93.1 & 43.68 & 43.5 & 27.8 & 79.6 \\
\hline 40 & 12411000 & $\begin{array}{l}\text { North Fork Coeur d'Alene River above Shoshone Creek, } \\
\text { near Prichard, ID }\end{array}$ & 334.0 & $3,947.0$ & 89.7 & 48.25 & 40.8 & 24.7 & 75.6 \\
\hline 41 & 12413000 & North Fork Coeur d'Alene River at Enaville, ID & 893.7 & $3,835.9$ & 88.9 & 45.38 & 41.9 & 25.4 & 77.6 \\
\hline 42 & 12413100 & Boulder Creek at Mullan, ID & 3.1 & $5,212.4$ & 93.2 & 49.41 & 46.7 & 33.1 & 83.0 \\
\hline 43 & 12413140 & Placer Creek at Wallace, ID & 15.0 & $4,411.0$ & 94.2 & 41.53 & 49.6 & 31.2 & 88.8 \\
\hline 44 & 12413150 & South Fork Coeur d'Alene River at Silverton, ID & 105.6 & $4,615.4$ & 89.8 & 42.52 & 45.8 & 27.5 & 82.3 \\
\hline 45 & 12413200 & Montgomery Creek near Kellogg, ID & 4.5 & $3,648.3$ & 91.8 & 40.23 & 48.0 & 13.6 & 89.3 \\
\hline 46 & 12413210 & South Fork Coeur d'Alene at Elizabeth Park near Kellogg, ID & 181.8 & $4,301.2$ & 88.5 & 43.34 & 45.8 & 27.2 & 82.5 \\
\hline 47 & 12413470 & South Fork Coeur d'Alene River near Pinehurst, ID & 287.1 & $4,096.4$ & 83.5 & 45.09 & 44.6 & 26.9 & 80.7 \\
\hline 48 & 12413500 & Coeur d'Alene River at Cataldo, ID & $1,207.4$ & $3,878.0$ & 87.3 & 45.01 & 42.3 & 25.5 & 77.8 \\
\hline 49 & 12413700 & Latour Creek near Cataldo, ID & 24.8 & $4,316.0$ & 85.6 & 54.84 & 41.8 & 27.9 & 81.6 \\
\hline 50 & 12414500 & St. Joe River at Calder, ID & $1,024.5$ & $4,545.6$ & 89.8 & 46.95 & 41.3 & 24.7 & 74.4 \\
\hline 51 & 12414900 & St. Maries River near Santa, ID & 272.6 & $3,592.6$ & 80.6 & 37.73 & 25.1 & 12.5 & 34.9 \\
\hline 52 & 12415000 & St. Maries River at Lotus, ID & 434.5 & $3,465.5$ & 82.2 & 35.63 & 23.8 & 11.4 & 31.7 \\
\hline 53 & 12415100 & Cherry Creek near St. Maries, ID & 7.1 & $3,308.1$ & 86.4 & 31.71 & 30.3 & 23.5 & 51.3 \\
\hline 54 & 12415200 & Plummer Creek Tributary at Plummer, ID & 2.0 & $2,966.3$ & 35.9 & 20.00 & 15.2 & 1.5 & 9.9 \\
\hline 55 & 12416000 & Hayden Creek below North Fork, near Hayden Lake, ID & 21.5 & $3,564.7$ & 95.1 & 38.75 & 41.8 & 25.3 & 81.2 \\
\hline 56 & 13336500 & Selway River near Lowell, ID & $1,913.1$ & $5,511.8$ & 82.8 & 40.58 & 44.2 & 24.1 & 785.6 \\
\hline 57 & 13336600 & Swiftwater Creek near Lowell, ID & 6.2 & $3,814.8$ & 93.7 & 33.22 & 42.7 & 39.6 & 80.2 \\
\hline 58 & 13336650 & East Fork Papoose Creek near Powell Ranger Station, ID & 4.5 & $4,832.2$ & 82.4 & 47.61 & 47.2 & 17.1 & 87.9 \\
\hline 59 & 13336850 & Weir Creek near Powell Ranger Station, ID & 12.2 & $4,817.1$ & 86.5 & 48.18 & 48.7 & 13.9 & 88.5 \\
\hline 60 & 13336900 & Fish Creek near Lowell, ID & 88.3 & $4,467.2$ & 91.3 & 46.34 & 34.7 & 13.7 & 55.7 \\
\hline 61 & 13337000 & Lochsa River near Lowell, ID & $1,179.4$ & $5,197.2$ & 88.2 & 46.62 & 38.5 & 20.4 & 63.5 \\
\hline 62 & 13340500 & North Fork Clearwater River at Bungalow Ranger Station, ID & 997.5 & $4,888.8$ & 82.2 & 52.47 & 39.0 & 22.1 & 68.1 \\
\hline 63 & 13340600 & North Fork Clearwater River near Canyon Ranger Station, ID & $1,294.2$ & $4,732.9$ & 82.9 & 51.40 & 40.4 & 22.7 & 69.9 \\
\hline 64 & 13341300 & Bloom Creek near Bovill, ID & 3.0 & $3,716.0$ & 86.8 & 48.07 & 32.0 & 27.6 & 55.6 \\
\hline 65 & 13341400 & East Fork Potlatch River near Bovill, ID & 42.7 & $3,617.2$ & 86.0 & 42.67 & 26.3 & 14.0 & 36.4 \\
\hline
\end{tabular}


Table 4. Basin and climatic characteristics for streamflow-gaging stations in Idaho and bordering States used in regional regression analysis--Continued

\begin{tabular}{|c|c|c|c|c|c|c|c|c|c|}
\hline $\begin{array}{l}\text { Map } \\
\text { No. } \\
\end{array}$ & $\begin{array}{c}\text { Gaging } \\
\text { station No. }\end{array}$ & Gaging station name & $\begin{array}{c}\mathrm{DA} \\
\left(\mathrm{mi}^{2}\right)\end{array}$ & $\begin{array}{c}E \\
(f t)\end{array}$ & $\begin{array}{c}\mathbf{F} \\
\text { (percent) } \\
\end{array}$ & $\begin{array}{c}P \\
\text { (in.) } \\
\end{array}$ & $\begin{array}{c}\text { BS } \\
\text { (percent) }\end{array}$ & $\begin{array}{c}\text { NF30 } \\
\text { (percent) }\end{array}$ & $\begin{array}{c}\mathrm{S} 30 \\
\text { (percent) }\end{array}$ \\
\hline & & \multicolumn{8}{|c|}{ REGION 3} \\
\hline 66 & 12423550 & Hangman Creek Tributary near Latah, WA & 2.3 & $2,693.4$ & 1.1 & 20.41 & 11.4 & 1.7 & 1.9 \\
\hline 67 & 12423700 & South Fork Rock Creek Tributary near Fairfield, WA & 0.6 & $2,720.9$ & 7.9 & 19.91 & 11.0 & 2.6 & 3.2 \\
\hline 68 & 12423900 & Stevens Creek Tributary near Moran, WA & 2.0 & $2,671.8$ & 9.9 & 18.97 & 17.2 & 0.9 & 2.0 \\
\hline 69 & 12424000 & Hangman Creek at Spokane, WA & 674.9 & $2,647.1$ & 19.4 & 20.83 & 10.5 & 2.3 & 6.7 \\
\hline 70 & 13334700 & Asotin Creek below Kearney Gulch near Asotin, WA & 170.5 & $3,752.2$ & 30.5 & 23.01 & 35.4 & 20.7 & 57.5 \\
\hline 71 & 13335200 & Critchfield Draw near Clarkston, WA & 2.0 & $1,472.6$ & 0.2 & 11.90 & 12.7 & 0.9 & 3.9 \\
\hline 72 & 13341100 & Cold Springs Creek near Craigmont, ID & 8.2 & $4,040.1$ & 10.7 & 20.00 & 8.9 & 0.2 & 1.0 \\
\hline 73 & 13341500 & Potlatch River at Kendrick, ID & 453.7 & $2,969.1$ & 59.8 & 29.51 & 18.2 & 5.5 & 17.8 \\
\hline 74 & 13342450 & Lapwai Creek near Lapwai, ID & 268.9 & $3,149.2$ & 30.7 & 19.31 & 18.9 & 7.7 & 22.2 \\
\hline 75 & 13343450 & Dry Creek at mouth near Clarkston, WA & 7.5 & $1,458.4$ & 0.2 & 12.08 & 8.6 & 0.1 & 1.4 \\
\hline 76 & 13343800 & Meadow Creek near Central Ferry, WA & 67.2 & $1,898.5$ & 0.0 & 16.12 & 14.2 & 2.3 & 6.7 \\
\hline 77 & 13344500 & Tucannon River near Starbuck, WA & 431.8 & $2,943.7$ & 23.7 & 23.98 & 26.4 & 11.9 & 36.0 \\
\hline 78 & 13344700 & Deep Creek Tributary near Polatch, ID & 2.9 & $3,156.8$ & 87.6 & 28.67 & 24.3 & 17.8 & 27.1 \\
\hline 79 & 13344800 & Deep Creek near Potlatch, ID & 35.8 & $2,977.9$ & 46.4 & 24.92 & 18.7 & 5.0 & 19.8 \\
\hline 80 & 13345000 & Palouse River near Potlatch, ID & 316.0 & $3,165.1$ & 63.4 & 30.07 & 21.2 & 9.0 & 25.8 \\
\hline 81 & 13346100 & Palouse River at Colfax, WA & 491.7 & $2,963.6$ & 41.7 & 26.93 & 17.7 & 6.2 & 17.8 \\
\hline 82 & 13346300 & Crumarine Creek near Moscow, ID & 2.4 & $3,694.1$ & 79.3 & 29.55 & 27.4 & 10.0 & 41.1 \\
\hline 83 & 13346800 & Paradise Creek at University of Idaho, at Moscow, ID & 17.6 & $2,844.2$ & 12.5 & 24.53 & 11.8 & 1.0 & 6.0 \\
\hline 84 & 13348000 & South Fork Palouse River at Pullman, WA & 126.9 & $2,745.5$ & 6.9 & 23.76 & 11.9 & 0.8 & 3.3 \\
\hline 85 & 13348500 & Missouri Flat Creek at Pullman, WA & 27.1 & $2,652.2$ & 0.6 & 23.23 & 10.0 & 0.0 & 0.0 \\
\hline 86 & 13349210 & Palouse River below South Fork at Colfax, WA & 788.7 & $2,842.0$ & 27.4 & 25.33 & 15.5 & 4.2 & 12.1 \\
\hline 87 & 13349400 & Pine Creek at Pine City, WA & 304.6 & $2,527.0$ & 1.6 & 19.00 & 9.1 & 0.5 & 1.2 \\
\hline 88 & 13350500 & Union Flat Creek near Colfax, WA & 189.8 & $2,691.9$ & 0.0 & 20.97 & 10.5 & 0.5 & 1.1 \\
\hline 89 & 14016000 & Dry Creek near Walla Walla, WA & 48.5 & $2,342.9$ & 18.4 & 30.10 & 21.4 & 8.9 & 23.7 \\
\hline 90 & 14016500 & East Fork Touchet River near Dayton, WA & 106.2 & $3,820.0$ & 59.8 & 42.10 & 38.9 & 21.0 & 65.9 \\
\hline \multirow[t]{2}{*}{91} & 14017000 & Touchet River at Bolles, WA & 363.3 & $2,928.8$ & 31.7 & 30.50 & 27.3 & 13.4 & 38.5 \\
\hline & & \multicolumn{8}{|c|}{ REGION 4} \\
\hline 92 & 13185500 & Cottonwood Creek at Arrowrock Reservoir, ID & 20.8 & $5,198.1$ & 36.8 & 19.08 & 39.8 & 18.4 & 70.7 \\
\hline 93 & 13196500 & Bannock Creek near Idaho City, ID & 4.8 & $5,313.2$ & 60.4 & 22.08 & 32.9 & 26.2 & 57.4 \\
\hline 94 & 13200000 & Mores Creek above Robie Creek, near Arrowrock Dam, ID & 397.0 & $5,070.8$ & 66.3 & 24.76 & 31.3 & 16.7 & 51.0 \\
\hline 95 & 13200500 & Robie Creek near Arrowrock Dam, ID & 16.0 & $4,680.6$ & 65.0 & 23.34 & 39.8 & 23.4 & 70.6 \\
\hline 96 & 13201000 & Mores Creek near Arrowrock, ID & 424.4 & $5,024.2$ & 65.0 & 24.48 & 31.7 & 17.0 & 52.0 \\
\hline 97 & 13207000 & Spring Valley Creek near Eagle, ID & 19.2 & $4,017.4$ & 8.0 & 19.42 & 24.3 & 9.3 & 30.2 \\
\hline 98 & 13207500 & Dry Creek near Eagle, ID & 59.4 & $3,963.4$ & 11.7 & 20.39 & 25.3 & 8.8 & 34.3 \\
\hline 99 & 13216500 & $\begin{array}{l}\text { North Fork Malheur River above Beulah Reservoir near } \\
\text { Beulah, OR }\end{array}$ & 342.5 & $5,360.8$ & 52.7 & 23.79 & 21.6 & 6.0 & 23.2 \\
\hline
\end{tabular}


Table 4. Basin and climatic characteristics for streamflow-gaging stations in Idaho and bordering States used in regional regression analysis--Continued

\begin{tabular}{|c|c|c|c|c|c|c|c|c|c|}
\hline $\begin{array}{l}\text { Map } \\
\text { No. } \\
\end{array}$ & $\begin{array}{c}\text { Gaging } \\
\text { station No. }\end{array}$ & Gaging station name & $\begin{array}{c}\mathrm{DA} \\
\left(\mathrm{mi}^{2}\right) \\
\end{array}$ & $\begin{array}{c}E \\
(\mathrm{ft})\end{array}$ & $\begin{array}{c}\mathbf{F} \\
\text { (percent) }\end{array}$ & $\begin{array}{c}P \\
\text { (in.) } \\
\end{array}$ & $\begin{array}{c}\text { BS } \\
\text { (percent) }\end{array}$ & $\begin{array}{c}\text { NF30 } \\
\text { (percent) }\end{array}$ & $\begin{array}{c}\mathrm{S} 30 \\
\text { (percent) }\end{array}$ \\
\hline & & \multicolumn{8}{|c|}{ REGION 4--Continued } \\
\hline 100 & 13248900 & Cottonwood Creek near Horseshoe Bend, ID & 7.0 & $3,882.5$ & 0.0 & 17.16 & 23.9 & 15.2 & 26.3 \\
\hline 101 & 13250600 & Big Willow Creek near Emmett, ID & 55.2 & $4,099.3$ & 4.8 & 15.88 & 23.6 & 7.3 & 28.0 \\
\hline 102 & 13250650 & Fourmile Creek near Emmett, ID & 6.2 & $3,804.1$ & 1.7 & 12.88 & 22.9 & 2.9 & 21.4 \\
\hline 103 & 13251300 & West Branch Weiser River near Tamarack, ID & 4.0 & $4,947.6$ & 81.5 & 39.75 & 27.3 & 3.2 & 41.5 \\
\hline 104 & 13251500 & Weiser River at Tamarack, ID & 36.6 & $4,654.2$ & 87.8 & 34.61 & 22.3 & 4.9 & 27.1 \\
\hline 105 & 13252500 & East Fork Weiser River near Council, ID & 2.3 & $6,883.5$ & 76.0 & 40.00 & 27.0 & 16.9 & 36.5 \\
\hline 106 & 13253500 & Weiser River at Starkey, ID & 105.4 & $4,969.7$ & 88.1 & 32.34 & 26.5 & 10.7 & 38.0 \\
\hline 107 & 13256000 & Weiser River near Council, ID & 391.9 & $4,668.2$ & 64.6 & 29.64 & 24.2 & 9.6 & 32.7 \\
\hline 108 & 13257000 & Middle Fork Weiser River near Mesa, ID & 86.1 & $5,430.2$ & 74.1 & 34.00 & 27.4 & 11.1 & 38.3 \\
\hline 109 & 13258500 & Weiser River near Cambridge, ID & 596.4 & $4,636.5$ & 58.2 & 29.23 & 23.5 & 8.7 & 30.6 \\
\hline 110 & 13260000 & Pine Creek near Cambridge, ID & 55.3 & $4,751.8$ & 42.3 & 22.43 & 26.4 & 10.0 & 37.9 \\
\hline 111 & 13261000 & Little Weiser River near Indian Valley, ID & 79.5 & $5,313.9$ & 67.1 & 28.23 & 26.9 & 11.2 & 36.5 \\
\hline 112 & 13266000 & Weiser River near Weiser, ID & $1,448.3$ & $4,141.3$ & 32.7 & 22.23 & 19.3 & 6.4 & 22.1 \\
\hline 113 & 13267000 & Mann Creek near Weiser, ID & 56.8 & $4,846.2$ & 55.4 & 22.12 & 31.6 & 10.6 & 53.4 \\
\hline 114 & 13267100 & Deer Creek near Midvale, ID & 4.3 & $3,233.7$ & 1.1 & 10.00 & 15.7 & 0.5 & 6.1 \\
\hline 115 & 13269300 & North Fork Burnt River near Whitney, OR & 110.8 & $4,901.1$ & 81.6 & 25.11 & 18.7 & 4.5 & 17.7 \\
\hline 116 & 13270800 & South Fork Burnt River above Barney Creek near Unity, OR & 38.9 & $5,823.5$ & 91.6 & 28.59 & 28.2 & 16.9 & 42.0 \\
\hline 117 & 13275500 & Powder River near Baker, OR & 205.2 & $5,224.6$ & 74.5 & 24.67 & 26.5 & 9.6 & 40.8 \\
\hline 118 & 13288200 & Eagle Creek above Skull Creek near New Bridge, OR & 155.7 & $5,742.6$ & 67.6 & 47.53 & 40.5 & 14.5 & 63.7 \\
\hline 119 & 13289100 & Immigrant Gulch near Richlavel, OR & 6.7 & $3,581.4$ & 1.4 & 24.97 & 25.4 & 3.1 & 32.3 \\
\hline 120 & 13289600 & East Brownlee Creek at Brownlee Ranger Station, ID & 7.4 & $5,913.0$ & 79.2 & 30.00 & 44.9 & 18.5 & 78.9 \\
\hline 121 & 13289960 & Wildhorse River at Brownlee Dam, ID & 177.1 & $5,037.5$ & 62.2 & 27.53 & 29.4 & 14.3 & 43.3 \\
\hline 122 & 13290190 & Pine Creek near Oxbow, OR & 298.5 & $4,287.7$ & 50.2 & 33.71 & 27.4 & 9.8 & 40.0 \\
\hline 123 & 13291000 & Imnaha River above Gumboot Creek, OR & 99.8 & $6,374.4$ & 64.6 & 56.25 & 37.0 & 21.0 & 58.7 \\
\hline 124 & 13291200 & Mahogany Creek near Homestead, OR & 4.1 & $5,192.1$ & 75.4 & 37.19 & 33.5 & 18.5 & 53.2 \\
\hline 125 & 13315500 & Mud Creek near Tamarack, ID & 15.1 & $4,742.2$ & 93.0 & 35.36 & 27.4 & 6.7 & 45.0 \\
\hline 126 & 13316500 & Little Salmon River at Riggins, ID & 576.1 & $5,421.1$ & 71.8 & 29.61 & 33.4 & 15.5 & 51.5 \\
\hline 127 & 13316800 & North Fork Skookumchuck Creek near White Bird, ID & 15.3 & $5,031.2$ & 69.3 & 30.22 & 30.6 & 15.8 & 44.2 \\
\hline 128 & 13317000 & Salmon River at White Bird, ID & $13,418.3$ & $6,753.8$ & 58.3 & 24.72 & 37.7 & 19.1 & 60.3 \\
\hline 129 & 13317200 & Johns Creek near Grangeville, ID & 5.0 & $3,961.5$ & 33.1 & 24.22 & 11.7 & 8.5 & 10.9 \\
\hline 130 & 13319000 & Grande Ronde River at La Grande, OR & 687.4 & $4,582.0$ & 68.4 & 27.57 & 20.3 & 6.5 & 21.8 \\
\hline 131 & 13320000 & Catherine Creek near Union, OR & 104.1 & $5,263.8$ & 85.9 & 39.66 & 28.6 & 10.6 & 40.8 \\
\hline 132 & 13323600 & Indian Creek near Imbler, OR & 24.8 & $5,515.7$ & 77.1 & 43.58 & 21.3 & 6.3 & 20.8 \\
\hline 133 & 13329500 & Hurricane Creek near Joseph, OR & 29.6 & $7,461.3$ & 47.0 & 64.64 & 57.2 & 22.9 & 87.0 \\
\hline 134 & 13330000 & Lostine River near Lostine, OR & 71.5 & $6,893.5$ & 52.1 & 56.69 & 49.2 & 22.1 & 77.2 \\
\hline
\end{tabular}


Table 4. Basin and climatic characteristics for streamflow-gaging stations in Idaho and bordering States used in regional regression analysis--Continued

\begin{tabular}{|c|c|c|c|c|c|c|c|c|c|}
\hline $\begin{array}{l}\text { Map } \\
\text { No. } \\
\end{array}$ & $\begin{array}{c}\text { Gaging } \\
\text { station No. }\end{array}$ & Gaging station name & $\begin{array}{c}\text { DA } \\
\left(\mathrm{mi}^{2}\right) \\
\end{array}$ & $\begin{array}{c}E \\
(f t)\end{array}$ & $\begin{array}{c}\mathbf{F} \\
\text { (percent) }\end{array}$ & $\begin{array}{c}P \\
\text { (in.) } \\
\end{array}$ & $\begin{array}{c}\text { BS } \\
\text { (percent) }\end{array}$ & $\begin{array}{c}\text { NF30 } \\
\text { (percent) }\end{array}$ & $\begin{array}{c}\mathrm{S} 30 \\
\text { (percent) }\end{array}$ \\
\hline & & \multicolumn{8}{|c|}{ REGION 4--Continued } \\
\hline 135 & 13330500 & Bear Creek near Wallowa, OR & 72.1 & $5,804.7$ & 67.2 & 44.74 & 45.6 & 23.2 & 75.0 \\
\hline 136 & 13331500 & Minam River at Minam, OR & 239.2 & $5,699.5$ & 66.4 & 46.47 & 43.5 & 21.3 & 70.5 \\
\hline 137 & 13337200 & Red Horse Creek near Elk City, ID & 9.1 & $5,052.5$ & 93.9 & 36.37 & 27.9 & 11.9 & 42.3 \\
\hline 138 & 13337500 & South Fork Clearwater River near Elk City, ID & 260.8 & $5,095.1$ & 91.7 & 35.30 & 24.1 & 10.1 & 28.8 \\
\hline 139 & 13337700 & Peasley Creek near Golden, ID & 14.2 & $4,880.8$ & 94.3 & 35.81 & 35.0 & 9.5 & 57.9 \\
\hline 140 & 13338000 & South Fork Clearwater River near Grangeville, ID & 843.4 & $5,116.5$ & 91.8 & 34.88 & 29.7 & 14.0 & 42.4 \\
\hline 141 & 13338200 & Sally Ann Creek near Stites, ID & 13.8 & $3,142.8$ & 57.6 & 31.08 & 24.8 & 16.6 & 32.0 \\
\hline 142 & 13338500 & South Fork Clearwater River at Stites, ID & $1,168.3$ & $4,546.6$ & 70.5 & 31.31 & 25.7 & 11.9 & 35.1 \\
\hline 143 & 13339000 & Clearwater River at Kamiah, ID & $4,827.4$ & $4,956.2$ & 77.4 & 38.29 & 36.2 & 19.1 & 58.6 \\
\hline 144 & 13339500 & Lolo Creek near Greer, ID & 241.4 & $3,528.6$ & 84.1 & 31.53 & 22.6 & 8.4 & 25.5 \\
\hline 145 & 13339700 & Canal Gulch Creek at Pierce Ranger Station, ID & 6.4 & $3,539.5$ & 92.2 & 40.00 & 17.5 & 1.1 & 8.5 \\
\hline 146 & 13339900 & Deer Creek near Orofino, ID & 5.2 & $2,955.8$ & 82.6 & 29.82 & 18.0 & 7.2 & 17.7 \\
\hline 147 & 13340000 & Clearwater River at Orofino, ID & $5,507.9$ & $4,736.4$ & 76.6 & 37.36 & 34.4 & 17.7 & 54.5 \\
\hline 148 & 14010000 & South Fork Walla Walla River near Milton, OR & 61.9 & $4,273.1$ & 68.3 & 46.44 & 46.3 & 21.9 & 74.7 \\
\hline 149 & 14011000 & North Fork Walla Walla River near Milton, OR & 42.6 & $3,640.0$ & 57.2 & 42.17 & 42.1 & 23.9 & 71.2 \\
\hline 150 & 14013000 & Mill Creek near Walla Walla, WA & 58.8 & $3,933.2$ & 68.6 & 47.97 & 50.5 & 28.8 & 85.5 \\
\hline \multirow[t]{2}{*}{151} & 14013500 & Blue Creek near Walla Walla, WA & 17.1 & $3,136.4$ & 45.7 & 40.52 & 38.3 & 24.9 & 68.8 \\
\hline & & \multicolumn{8}{|c|}{ REGION 5} \\
\hline 152 & 12343400 & East Fork Bitterroot River near Conner, MT & 379.3 & $6,361.7$ & 78.6 & 28.42 & 33.2 & 18.1 & 55.1 \\
\hline 153 & 12346500 & Skalkaho Creek near Hamilton, MT & 88.1 & $6,676.0$ & 86.4 & 29.55 & 38.8 & 22.5 & 67.5 \\
\hline 154 & 12351000 & Burnt Fork Bitterroot River near Stevensville, MT & 73.0 & $6,495.2$ & 79.6 & 30.60 & 36.5 & 21.3 & 62.0 \\
\hline 155 & 12351400 & Eightmile Creek near Florence, MT & 20.8 & $5,389.4$ & 62.1 & 24.51 & 39.1 & 24.2 & 69.3 \\
\hline 156 & 13135200 & Prairie Creek near Ketchum, ID & 17.3 & $8,558.1$ & 59.0 & 34.44 & 45.9 & 24.1 & 72.1 \\
\hline 157 & 13135500 & Big Wood River near Ketchum, ID & 137.5 & $8,204.0$ & 55.8 & 31.42 & 40.6 & 20.8 & 67.5 \\
\hline 158 & 13135800 & Adams Gulch near Ketchum, ID & 10.5 & $7,373.5$ & 61.5 & 30.69 & 42.5 & 32.9 & 79.2 \\
\hline 159 & 13136500 & Warm Springs Creek at Guyer Hot Springs, near Ketchum, ID & 92.6 & $7,696.0$ & 59.7 & 35.77 & 42.6 & 23.1 & 77.8 \\
\hline 160 & 13139500 & Big Wood River at Hailey, ID & 627.6 & $7,685.6$ & 43.2 & 29.35 & 42.7 & 22.1 & 74.0 \\
\hline 161 & 13141000 & Big Wood River near Bellevue, ID & 786.2 & $7,347.3$ & 35.5 & 26.45 & 40.2 & 20.8 & 69.3 \\
\hline 162 & 13141400 & Deer Creek near Fairfield, ID & 11.8 & $6,496.3$ & 30.1 & 19.80 & 33.4 & 13.1 & 62.2 \\
\hline 163 & 13184200 & Roaring River near Rocky Bar, ID & 22.1 & $7,274.7$ & 61.3 & 41.26 & 32.6 & 15.7 & 46.8 \\
\hline 164 & 13184800 & Beaver Creek near Lowman, ID & 10.0 & $5,796.4$ & 52.1 & 32.14 & 24.2 & 7.8 & 29.9 \\
\hline 165 & 13185000 & Boise River near Twin Springs, ID & 831.6 & $6,415.7$ & 50.2 & 32.42 & 44.3 & 23.2 & 75.1 \\
\hline 166 & 13186000 & South Fork Boise River near Featherville, ID & 641.6 & $7,025.2$ & 50.6 & 34.72 & 42.1 & 21.5 & 74.4 \\
\hline 167 & 13186500 & Lime Creek near Bennett, ID & 133.6 & $6,276.7$ & 22.4 & 22.40 & 29.3 & 11.4 & 47.3 \\
\hline 168 & 13187000 & Fall Creek near Anderson Ranch Dam, ID & 55.6 & $6,171.1$ & 59.2 & 32.16 & 33.6 & 14.0 & 59.3 \\
\hline 169 & 13234300 & Fivemile Creek nr Lowman, ID & 11.3 & $6,623.7$ & 49.9 & 32.33 & 44.6 & 14.7 & 76.2 \\
\hline
\end{tabular}


Table 4. Basin and climatic characteristics for streamflow-gaging stations in Idaho and bordering States used in regional regression analysis--Continued

\begin{tabular}{|c|c|c|c|c|c|c|c|c|c|}
\hline $\begin{array}{l}\text { Map } \\
\text { No. }\end{array}$ & $\begin{array}{c}\text { Gaging } \\
\text { station No. }\end{array}$ & Gaging station name & $\begin{array}{c}\text { DA } \\
\left(\mathrm{mi}^{2}\right)\end{array}$ & $\begin{array}{c}E \\
(\mathrm{ft})\end{array}$ & $\begin{array}{c}\mathbf{F} \\
\text { (percent) }\end{array}$ & $\begin{array}{c}P \\
\text { (in.) } \\
\end{array}$ & $\begin{array}{c}\text { BS } \\
\text { (percent) }\end{array}$ & $\begin{array}{c}\text { NF30 } \\
\text { (percent) }\end{array}$ & $\begin{array}{c}\mathrm{S} 30 \\
\text { (percent) }\end{array}$ \\
\hline & & \multicolumn{8}{|c|}{ REGION 5--Continued } \\
\hline 170 & 13235000 & South Fork Payette River at Lowman, ID & 449.3 & $6,824.5$ & 54.3 & 34.51 & 46.7 & 23.2 & 76.6 \\
\hline 171 & 13235100 & Rock Creek at Lowman, ID & 16.5 & $5,793.4$ & 63.3 & 31.40 & 39.5 & 25.9 & 72.2 \\
\hline 172 & 13237300 & Danskin Creek near Crimes Pass, ID & 10.0 & $4,779.2$ & 68.8 & 26.49 & 46.3 & 16.1 & 83.7 \\
\hline 173 & 13238300 & Deep Creek near McCall, ID & 3.6 & $7,255.3$ & 60.3 & 49.73 & 22.5 & 2.5 & 23.4 \\
\hline 174 & 13240000 & Lake Fork Payette River above Jumbo Creek, near McCall, ID & 48.7 & $6,921.9$ & 71.6 & 37.22 & 42.1 & 16.5 & 67.9 \\
\hline 175 & 13240500 & Lake Fork Payette River above Reservoir near McCall, ID & 51.7 & $6,905.7$ & 72.6 & 36.82 & 41.0 & 15.7 & 65.6 \\
\hline 176 & 13245400 & Tripod Creek at Smiths Ferry, ID & 8.6 & $5,514.1$ & 87.7 & 28.13 & 19.8 & 3.6 & 18.3 \\
\hline 177 & 13292400 & Beaver Creek near Stanley, ID & 14.9 & $8,255.9$ & 57.7 & 41.59 & 35.4 & 22.1 & 56.9 \\
\hline 178 & 13292500 & Salmon River near Obsidian, ID & 93.9 & $8,181.1$ & 56.9 & 34.66 & 32.8 & 17.8 & 53.1 \\
\hline 179 & 13293000 & Alturas Lake Creek near Obsidian, ID & 35.6 & $8,161.5$ & 47.1 & 44.47 & 37.6 & 19.0 & 60.4 \\
\hline 180 & 13295000 & Valley Creek at Stanley, ID & 148.9 & $7,318.8$ & 63.0 & 23.94 & 26.1 & 12.0 & 37.0 \\
\hline 181 & 13295500 & Salmon River below Valley Creek, at Stanley, ID & 510.4 & $7,786.2$ & 54.9 & 29.61 & 30.4 & 14.6 & 45.2 \\
\hline 182 & 13296000 & Yankee Fork Salmon River near Clayton, ID & 187.3 & $7,992.1$ & 74.5 & 27.11 & 41.0 & 22.7 & 71.1 \\
\hline 183 & 13296500 & Salmon River below Yankee Fork, near Clayton, ID & 811.1 & 7,791.6 & 61.9 & 27.95 & 33.6 & 17.1 & 53.7 \\
\hline 184 & 13297100 & Peach Creek near Clayton, ID & 7.6 & $7,809.8$ & 78.1 & 22.53 & 47.1 & 16.6 & 87.1 \\
\hline 185 & 13308500 & Middle Fork Salmon River near Cape Horn, ID & 133.8 & $7,482.6$ & 70.8 & 28.40 & 26.6 & 11.6 & 40.2 \\
\hline 186 & 13309000 & Bear Valley Creek near Cape Horn, ID & 181.7 & $7,060.3$ & 70.1 & 30.02 & 20.2 & 7.6 & 24.7 \\
\hline 187 & 13309220 & Middle Fork Salmon River near Yellow Pine, ID & $1,038.7$ & $7,189.7$ & 68.9 & 29.00 & 38.4 & 20.3 & 64.1 \\
\hline 188 & 13310000 & Big Creek near Big Creek, ID & 451.5 & $6,981.2$ & 78.6 & 28.71 & 44.3 & 24.6 & 74.0 \\
\hline 189 & 13310500 & South Fork Salmon River near Knox, ID & 91.7 & $6,631.3$ & 88.7 & 37.46 & 31.7 & 18.3 & 52.9 \\
\hline 190 & 13310700 & South Fork Salmon River near Krassel Ranger Station, ID & 329.3 & $6,381.8$ & 83.7 & 33.62 & 38.0 & 19.9 & 63.8 \\
\hline 191 & 13311000 & East Fork South Fork Salmon River at Stibnite, ID & 19.3 & $7,724.4$ & 83.7 & 34.05 & 35.3 & 20.4 & 62.6 \\
\hline 192 & 13311500 & East Fork South Fork Salmon River near Stibnite, ID & 42.9 & $7,619.9$ & 77.3 & 30.88 & 40.8 & 22.8 & 72.5 \\
\hline 193 & 13312000 & East Fork South Fork Salmon River near Yellow Pine, ID & 106.9 & $7,404.6$ & 78.2 & 30.02 & 41.7 & 22.2 & 73.0 \\
\hline 194 & 13313000 & Johnson Creek at Yellow Pine, ID & 216.4 & $7,135.2$ & 91.7 & 34.31 & 28.2 & 11.3 & 40.7 \\
\hline 195 & 13313500 & Secesh River near Burgdorf, ID & 100.5 & $6,963.9$ & 82.7 & 43.91 & 24.8 & 10.7 & 61.8 \\
\hline 196 & 13314000 & South Fork Salmon River near Warren, ID & $1,164.0$ & $6,696.9$ & 81.2 & 33.15 & 37.4 & 18.4 & 60.5 \\
\hline \multirow[t]{2}{*}{197} & 13315000 & Salmon River near French Creek, ID & $12,228.0$ & $6,913.7$ & 57.4 & 24.41 & 37.8 & 19.3 & 60.4 \\
\hline & & \multicolumn{8}{|c|}{ REGION 6} \\
\hline 198 & 06013500 & Big Sheep Creek below Muddy Creek near Dell, MT & 277.0 & $7,928.2$ & 14.5 & 18.82 & 24.1 & 10.1 & 31.8 \\
\hline 199 & 06015500 & Grasshopper Creek near Dillon, MT & 349.0 & $6,940.1$ & 28.9 & 19.22 & 18.8 & 5.6 & 19.6 \\
\hline 200 & 06019500 & Ruby River above reservoir near Alder, MT & 525.5 & $7,235.2$ & 26.0 & 22.93 & 20.1 & 6.2 & 20.5 \\
\hline 201 & 13108500 & Camas Creek at Eighteenmile Shearing Corral, near Kilgore, ID & 228.4 & $6,943.3$ & 39.4 & 26.84 & 12.8 & 3.2 & 12.8 \\
\hline 202 & 13112000 & Camas Creek at Camas, ID & 393.9 & $6,428.8$ & 22.9 & 21.10 & 8.6 & 1.9 & 7.5 \\
\hline
\end{tabular}


Table 4. Basin and climatic characteristics for streamflow-gaging stations in Idaho and bordering States used in regional regression analysis--Continued

\begin{tabular}{|c|c|c|c|c|c|c|c|c|c|}
\hline $\begin{array}{l}\text { Map } \\
\text { No. }\end{array}$ & $\begin{array}{c}\text { Gaging } \\
\text { station No. }\end{array}$ & Gaging station name & $\begin{array}{c}\text { DA } \\
\left(\mathrm{mi}^{2}\right)\end{array}$ & $\begin{array}{c}E \\
(f t)\end{array}$ & $\begin{array}{c}\mathbf{F} \\
\text { (percent) }\end{array}$ & $\begin{array}{c}P \\
\text { (in.) } \\
\end{array}$ & $\begin{array}{c}\text { BS } \\
\text { (percent) }\end{array}$ & $\begin{array}{c}\text { NF30 } \\
\text { (percent) }\end{array}$ & $\begin{array}{c}\mathrm{S} 30 \\
\text { (percent) }\end{array}$ \\
\hline & & \multicolumn{8}{|c|}{ REGION 6--Continued } \\
\hline 203 & 13112900 & Huntley Canyon at Spencer, ID & 4.0 & $6,820.0$ & 58.0 & 17.33 & 24.8 & 11.2 & 33.1 \\
\hline 204 & 13113000 & Beaver Creek at Spencer, ID & 123.2 & $7,027.5$ & 29.9 & 20.29 & 19.6 & 7.9 & 23.5 \\
\hline 205 & 13113500 & Beaver Creek at Dubois, ID & 238.7 & $6,696.9$ & 24.4 & 19.42 & 16.7 & 5.1 & 18.8 \\
\hline 206 & 13117200 & Main Fork near Goldburg, ID & 16.2 & $8,734.8$ & 49.7 & 26.30 & 32.6 & 10.9 & 53.0 \\
\hline 207 & 13117300 & Sawmill Creek near Goldburg, ID & 74.2 & $8,380.5$ & 54.1 & 23.79 & 32.7 & 14.2 & 53.7 \\
\hline 208 & 13120000 & North Fork Big Lost River at Wild Horse, near Chilly, ID & 114.7 & $8,659.7$ & 58.1 & 29.80 & 43.1 & 22.0 & 72.1 \\
\hline 209 & 13120500 & Big Lost River at Howell Ranch, near Chilly, ID & 440.4 & $8,626.3$ & 37.9 & 26.96 & 37.8 & 17.9 & 60.8 \\
\hline 210 & 13128900 & Lower Cedar Creek above Diversion 3, near Mackay, ID & 8.4 & $9,461.0$ & 21.0 & 26.61 & 66.2 & 17.1 & 94.2 \\
\hline 211 & 13297300 & Holman Creek near Clayton, ID & 6.1 & $7,298.7$ & 69.6 & 20.81 & 36.6 & 24.9 & 61.5 \\
\hline 212 & 13297330 & Thompson Creek near Clayton, ID & 29.5 & $7,618.4$ & 68.9 & 22.60 & 47.7 & 23.5 & 85.8 \\
\hline 213 & 13297350 & Bruno Creek near Clayton, ID & 6.4 & $7,520.2$ & 66.3 & 21.74 & 40.8 & 21.2 & 68.3 \\
\hline 214 & 13297355 & Squaw Creek below Bruno Creek, near Clayton, ID & 71.6 & $7,729.2$ & 73.0 & 25.17 & 36.3 & 16.3 & 60.2 \\
\hline 215 & 13297450 & Little Boulder Creek near Clayton, ID & 18.3 & $8,951.8$ & 39.2 & 31.98 & 41.3 & 23.5 & 64.3 \\
\hline 216 & 13298000 & East Fork Salmon River near Clayton, ID & 540.2 & $8,092.5$ & 31.7 & 26.00 & 38.2 & 20.6 & 62.7 \\
\hline 217 & 13298300 & Malm Gulch near Clayton, ID & 9.3 & $7,015.7$ & 9.4 & 20.99 & 36.3 & 16.8 & 63.5 \\
\hline 218 & 13299000 & Challis Creek near Challis, ID & 84.6 & $7,780.8$ & 62.4 & 25.59 & 37.2 & 18.3 & 62.0 \\
\hline 219 & 13301700 & Morse Creek above Diversion near May, ID & 17.9 & $8,178.6$ & 45.4 & 21.25 & 51.4 & 26.7 & 87.5 \\
\hline 220 & 13301800 & Morse Creek near May, ID & 20.0 & $7,926.5$ & 40.7 & 20.24 & 47.9 & 24.1 & 80.6 \\
\hline 221 & 13302500 & Salmon River at Salmon, ID & $3,746.1$ & $7,397.5$ & 37.3 & 21.63 & 33.4 & 16.7 & 52.9 \\
\hline 222 & 13305000 & Lemhi River near Lemhi, ID & 907.1 & $7,430.9$ & 24.3 & 15.62 & 25.2 & 11.9 & 36.9 \\
\hline 223 & 13305500 & Lemhi River at Salmon, ID & $1,258.0$ & $7,108.2$ & 24.9 & 15.26 & 26.4 & 12.4 & 39.1 \\
\hline 224 & 13305700 & Dahlonega Creek at Gibbonsville, ID & 32.5 & $6,184.7$ & 90.9 & 25.32 & 45.2 & 18.8 & 86.3 \\
\hline 225 & 13305800 & Hughes Creek near North Fork, ID & 20.5 & $6,707.4$ & 83.9 & 27.88 & 41.3 & 20.7 & 75.8 \\
\hline 226 & 13306000 & North Fork Salmon River at North Fork, ID & 210.3 & $6,258.1$ & 77.8 & 22.87 & 43.6 & 23.1 & 78.0 \\
\hline 227 & 13306500 & Panther Creek near Shoup, ID & 520.7 & $7,028.2$ & 80.2 & 24.00 & 38.6 & 20.9 & 62.2 \\
\hline \multirow[t]{2}{*}{228} & 13307000 & Salmon River near Shoup, ID & $6,236.7$ & $7,154.3$ & 41.1 & 20.37 & 33.3 & 16.6 & 52.8 \\
\hline & & \multicolumn{8}{|c|}{ REGION 7a } \\
\hline 229 & 10315500 & Marys River above Hot Springs Creek near Deeth, NV & 389.8 & $6,589.8$ & 2.3 & 15.19 & 17.5 & 5.3 & 21.8 \\
\hline 230 & 10329500 & Martin Creek near Paradise Valley, NV & 176.2 & $6,210.4$ & 4.1 & 21.88 & 21.0 & 8.3 & 26.4 \\
\hline 231 & 10352500 & McDermitt Creek near Mc Dermitt, NV & 225.4 & $5,890.4$ & 1.4 & 17.00 & 17.3 & 4.3 & 17.2 \\
\hline 232 & 10353000 & East Fork Quinn River near McDermitt, NV & 137.9 & $6,117.4$ & 2.1 & 22.24 & 22.2 & 10.0 & 28.0 \\
\hline 233 & 10396000 & Donner And Blitzen River near Frenchglen, OR & 204.7 & $6,197.6$ & 22.4 & 29.07 & 16.2 & 5.5 & 15.2 \\
\hline 234 & 10406500 & Trout Creek near Denio, NV & 86.7 & $6,025.9$ & 3.9 & 16.86 & 23.1 & 9.0 & 31.2 \\
\hline 235 & 13155200 & Burns Gulch near Glenns Ferry, ID & 0.7 & $6,089.9$ & 1.3 & 25.00 & 30.7 & 1.7 & 53.2 \\
\hline 236 & 13155300 & Little Canyon Creek at Stout Crossing near Glenns Ferry, ID & 14.2 & $5,927.8$ & 3.0 & 23.47 & 25.2 & 8.3 & 36.8 \\
\hline
\end{tabular}


Table 4. Basin and climatic characteristics for streamflow-gaging stations in Idaho and bordering States used in regional regression analysis--Continued

\begin{tabular}{|c|c|c|c|c|c|c|c|c|c|}
\hline $\begin{array}{l}\text { Map } \\
\text { No. }\end{array}$ & $\begin{array}{c}\text { Gaging } \\
\text { station No. }\end{array}$ & Gaging station name & $\begin{array}{c}\mathrm{DA} \\
\left(\mathrm{mi}^{2}\right)\end{array}$ & $\begin{array}{c}E \\
(f t)\end{array}$ & $\begin{array}{c}\mathbf{F} \\
\text { (percent) }\end{array}$ & $\begin{array}{c}\mathbf{P} \\
\text { (in.) } \\
\end{array}$ & $\begin{array}{c}\text { BS } \\
\text { (percent) }\end{array}$ & $\begin{array}{c}\text { NF30 } \\
\text { (percent) }\end{array}$ & $\begin{array}{c}\mathrm{S} 30 \\
\text { (percent) }\end{array}$ \\
\hline & & \multicolumn{8}{|c|}{ REGION 7a--Continued } \\
\hline 237 & 13161200 & Seventy Six Creek near Charleston, NV & 3.6 & $7,067.5$ & 1.3 & 24.49 & 27.4 & 6.6 & 38.9 \\
\hline 238 & 13161300 & Meadow Creek near Rowland, NV & 57.6 & $6,597.0$ & 3.6 & 19.58 & 25.7 & 11.9 & 35.2 \\
\hline 239 & 13162200 & Jarbidge River at Jarbidge, NV & 22.6 & $8,260.7$ & 37.8 & 33.79 & 48.8 & 22.7 & 85.8 \\
\hline 240 & 13162400 & Buck Creek near Jarbidge, NV & 25.8 & $7,069.6$ & 13.7 & 22.42 & 17.9 & 7.7 & 18.8 \\
\hline 241 & 13162500 & East Fork Jarbidge River near Three Creek, ID & 84.9 & $7,603.0$ & 24.5 & 24.77 & 35.3 & 16.1 & 55.2 \\
\hline 242 & 13162600 & Columbet Creek near Jarbidge, NV & 3.5 & $7,028.8$ & 8.4 & 22.15 & 16.8 & 7.1 & 14.1 \\
\hline 243 & 13169500 & Big Jacks Creek near Bruneau, ID & 243.7 & $5,170.0$ & 0.0 & 13.81 & 10.1 & 2.3 & 7.4 \\
\hline 244 & 13170000 & Little Jacks Creek near Bruneau, ID & 103.4 & $5,067.4$ & 0.1 & 14.22 & 13.2 & 3.8 & 11.5 \\
\hline 245 & 13170100 & Sugar Creek Tributary near Grasmere, ID & 4.5 & $4,856.2$ & 0.0 & 10.00 & 8.0 & 0.0 & 0.2 \\
\hline 246 & 13172200 & Fossil Creek near Oreana, ID & 16.7 & $3,879.7$ & 2.1 & 9.79 & 11.4 & 4.2 & 11.0 \\
\hline 247 & 13172666 & West Fork Reynolds Creek near Reynolds, ID & 0.4 & $6,821.4$ & 40.2 & 15.00 & 17.5 & 6.0 & 10.4 \\
\hline 248 & 13172668 & East Fork Reynolds Creek near Reynolds, ID & 0.2 & $6,810.7$ & 3.3 & 25.00 & 13.3 & 0.4 & 0.6 \\
\hline 249 & 13172680 & Reynolds Creek at Toolgate Weir near Reynolds, ID & 18.7 & $6,133.6$ & 38.4 & 21.22 & 23.0 & 11.1 & 24.9 \\
\hline 250 & 13172720 & Macks Creek near Reynolds, ID & 12.5 & $4,883.0$ & 11.1 & 13.64 & 21.1 & 7.7 & 21.6 \\
\hline 251 & 13172735 & Salmon Creek near Reynolds, ID & 13.1 & $5,001.8$ & 5.5 & 14.66 & 26.1 & 9.7 & 36.3 \\
\hline 252 & 13172740 & Reynolds Creek at Outlet Weir near Reynolds, ID & 91.8 & $5,015.7$ & 12.4 & 14.83 & 20.2 & 7.2 & 20.7 \\
\hline 253 & 13172800 & Little Squaw Creek Tributary near Marsing, ID & 1.8 & $4,447.6$ & 0.0 & 10.00 & 14.3 & 0.1 & 8.3 \\
\hline 254 & 13178000 & Jordan Creek above Lone Tree Creek, near Jordan Vallley, ID & 454.2 & $5,781.8$ & 38.9 & 26.15 & 19.5 & 5.8 & 21.8 \\
\hline 255 & 13210300 & Bryans Run near Boise, ID & 9.1 & $3,605.5$ & 0.0 & 10.23 & 3.2 & 0.0 & 0.0 \\
\hline \multirow[t]{2}{*}{256} & 13226500 & Bully Creek at Warmsprings near Vale, OR & 535.3 & $4,133.8$ & 0.8 & 12.26 & 17.4 & 3.7 & 15.3 \\
\hline & & \multicolumn{8}{|c|}{ REGION 7b } \\
\hline 257 & 10119000 & Little Malad River above Elkhorn Reservoir, near Malad City, ID & 107.1 & $6,070.2$ & 8.1 & 13.20 & 17.7 & 6.1 & 17.8 \\
\hline 258 & 10122500 & Devil Creek above Campbell Creek, near Malad City, ID & 12.5 & $5,986.6$ & 9.4 & 15.08 & 17.5 & 4.7 & 17.9 \\
\hline 259 & 10123000 & Devil Creek above Evans Dividers, near Malad City, ID & 34.0 & $5,883.8$ & 11.1 & 16.79 & 20.8 & 6.6 & 24.4 \\
\hline 260 & 10172940 & Dove Creek near Park Valley, UT & 28.7 & $6,681.4$ & 0.7 & 17.00 & 17.5 & 3.7 & 13.7 \\
\hline 261 & 13057600 & Homer Creek near Herman, ID & 26.7 & $6,477.2$ & 14.9 & 15.65 & 9.0 & 0.6 & 1.4 \\
\hline 262 & 13057940 & Willow Creek below Tex Creek near Ririe, ID & 431.4 & $6,422.9$ & 19.2 & 16.61 & 13.3 & 2.8 & 8.4 \\
\hline 263 & 13073700 & Robbers Roost Creek near McCammon, ID & 3.9 & $6,767.0$ & 41.5 & 24.88 & 42.4 & 21.8 & 77.0 \\
\hline 264 & 13075000 & Marsh Creek near McCammon, ID & 367.4 & $5,587.7$ & 9.0 & 14.30 & 16.8 & 6.4 & 20.2 \\
\hline 265 & 13075600 & North Fork Pocatello Creek near Pocatello, ID & 14.0 & $5,756.2$ & 7.7 & 15.00 & 21.2 & 8.0 & 17.3 \\
\hline 266 & 13076200 & Bannock Creek near Pocatello, ID & 407.3 & $5,545.4$ & 7.3 & 16.28 & 16.4 & 6.9 & 18.7 \\
\hline 267 & 13077700 & George Creek near Yost, UT & 7.9 & $8,483.9$ & 40.7 & 23.66 & 32.3 & 29.7 & 51.8 \\
\hline 268 & 13079200 & Cassia Creek near Elba, ID & 81.2 & $6,460.8$ & 16.3 & 17.39 & 23.5 & 12.2 & 33.0 \\
\hline 269 & 13083000 & Trapper Creek near Oakley, ID & 52.4 & $6,339.4$ & 6.2 & 17.39 & 28.1 & 14.4 & 41.3 \\
\hline 270 & 13092000 & Rock Creek near Rock Creek, ID & 81.6 & $6,350.2$ & 9.4 & 14.46 & 31.6 & 13.8 & 48.7 \\
\hline
\end{tabular}


Table 4. Basin and climatic characteristics for streamflow-gaging stations in Idaho and bordering States used in regional regression analysis--Continued

\begin{tabular}{|c|c|c|c|c|c|c|c|c|c|}
\hline $\begin{array}{l}\text { Map } \\
\text { No. }\end{array}$ & $\begin{array}{c}\text { Gaging } \\
\text { station No. }\end{array}$ & Gaging station name & $\begin{array}{r}\text { DA } \\
\left(\mathrm{mi}^{2}\right)\end{array}$ & $\begin{array}{c}E \\
(f t)\end{array}$ & $\begin{array}{c}\mathbf{F} \\
\text { (percent) }\end{array}$ & $\begin{array}{c}\mathbf{P} \\
\text { (in.) }\end{array}$ & $\begin{array}{c}\text { BS } \\
\text { (percent) }\end{array}$ & $\begin{array}{c}\text { NF30 } \\
\text { (percent) }\end{array}$ & $\begin{array}{c}\mathrm{S} 30 \\
\text { (percent) }\end{array}$ \\
\hline & & \multicolumn{8}{|c|}{ REGION 7b--Continued } \\
\hline 271 & 13145700 & Schooler Screek near Gooding, ID & 2.1 & $5,624.1$ & 0.0 & 10.00 & 10.1 & 0.2 & 2.0 \\
\hline 272 & 13147300 & Muldoon Creek near Garfield Guard Station, ID & 12.3 & $8,395.8$ & 30.8 & 25.00 & 47.4 & 12.7 & 79.0 \\
\hline \multirow[t]{2}{*}{273} & 13148000 & Little Wood River at Campbell Ranch near Carey, ID & 263.4 & $7,045.9$ & 17.9 & 22.03 & 34.9 & 13.5 & 57.5 \\
\hline & & \multicolumn{8}{|c|}{ REGION 8} \\
\hline 274 & 06037500 & Madison River near West Yellowstone, MT & 434.9 & $7,900.0$ & 93.9 & 42.30 & 11.3 & 2.4 & 7.9 \\
\hline 275 & 09223000 & Hams Fork below Pole Creek near Frontier, WY & 128.6 & $8,466.6$ & 72.8 & 31.97 & 20.4 & 5.0 & 19.5 \\
\hline 276 & 10015700 & $\begin{array}{l}\text { Sulphur Creek above reservoir, below La Chapelle Creek, } \\
\text { near Evanston, WY }\end{array}$ & 58.5 & $7,971.5$ & 25.4 & 21.62 & 9.6 & 0.3 & 1.2 \\
\hline 277 & 10040000 & Thomas Fork near Geneva, ID & 45.4 & $7,243.6$ & 24.8 & 23.80 & 26.5 & 8.1 & 36.9 \\
\hline 278 & 10040500 & Salt Creek near Geneva, ID & 38.1 & $7,448.4$ & 51.3 & 26.84 & 27.9 & 8.3 & 42.9 \\
\hline 279 & 10041000 & Thomas Fork near Wyoming-Idaho State Line, WY & 113.8 & $7,330.7$ & 36.5 & 25.13 & 27.4 & 8.7 & 40.7 \\
\hline 280 & 10047500 & Montpelier Creek at Irrigators Weir, near Montpelier, ID & 50.6 & $7,360.5$ & 28.5 & 21.49 & 32.0 & 14.1 & 52.6 \\
\hline 281 & 10058600 & Bloomington Creek at Bloomington, ID & 24.3 & $7,684.3$ & 37.6 & 35.10 & 27.4 & 15.7 & 40.5 \\
\hline 282 & 10069000 & Georgetown Creek near Georgetown, ID & 21.9 & $7,824.2$ & 55.4 & 26.14 & 40.6 & 19.6 & 70.8 \\
\hline 283 & 10072800 & Eightmile Creek near Soda Springs, ID & 17.2 & 7,598.6 & 75.5 & 30.73 & 29.9 & 15.1 & 47.3 \\
\hline 284 & 10076400 & Soda Creek at Fivemile Meadows, near Soda Springs, ID & 42.5 & $6,193.0$ & 1.2 & 18.42 & 5.1 & 0.8 & 3.4 \\
\hline 285 & 10077000 & Soda Creek near Soda Springs, ID & 50.9 & $6,184.9$ & 2.3 & 18.19 & 6.1 & 1.7 & 5.5 \\
\hline 286 & 10084500 & Cottonwood Creek near Cleveland, ID & 62.4 & $6,720.9$ & 40.4 & 23.61 & 20.9 & 5.8 & 21.8 \\
\hline 287 & 10089500 & Mink Creek near Mink Creek, ID & 68.4 & $6,534.7$ & 40.0 & 26.57 & 28.6 & 14.9 & 42.4 \\
\hline 288 & 10090800 & Battle Creek Tributary near Treasureton, ID & 4.7 & $5,837.2$ & 2.2 & 15.10 & 17.4 & 4.8 & 10.3 \\
\hline 289 & 10093000 & Cub River near Preston, ID & 30.4 & $7,384.3$ & 53.7 & 36.05 & 31.3 & 13.9 & 49.4 \\
\hline 290 & 10096000 & Cub River above Maple Creek near Franklin, ID & 23.2 & $5,691.9$ & 2.5 & 14.22 & 19.8 & 5.1 & 18.0 \\
\hline 291 & 10099000 & High Creek near Richmond, UT & 16.3 & $7,655.4$ & 62.2 & 40.94 & 49.4 & 30.6 & 86.6 \\
\hline 292 & 13010000 & Snake River at south boundary of Y.N.P., WY & 477.4 & $7,232.2$ & 82.6 & 47.68 & 15.9 & 5.6 & 14.8 \\
\hline 293 & 13010065 & Snake River above Jackson Lake at Flagg Ranch, WY & 502.5 & $8,199.4$ & 82.8 & 47.42 & 15.8 & 5.5 & 14.7 \\
\hline 294 & 13011500 & Pacific Creek at Moran, WY & 162.7 & $8,134.7$ & 72.4 & 36.25 & 20.3 & 6.1 & 20.8 \\
\hline 295 & 13011800 & Blackrock Creek Tributary near Moran, WY & 2.5 & $9,690.1$ & 39.2 & 39.20 & 22.8 & 2.8 & 23.2 \\
\hline 296 & 13011900 & Buffalo Fork above Lava Creek near Moran, WY & 330.1 & $8,951.0$ & 59.7 & 37.05 & 27.0 & 12.1 & 33.9 \\
\hline 297 & 13012000 & Buffalo Fork near Moran, WY & 370.2 & $8,815.8$ & 60.2 & 35.58 & 26.3 & 11.5 & 32.8 \\
\hline 298 & 13014500 & Gros Ventre River at Kelly, WY & 608.0 & $8,863.0$ & 62.6 & 31.62 & 23.3 & 8.3 & 26.9 \\
\hline 299 & 13015000 & Gros Ventre River at Zenith, WY & 627.2 & $8,792.9$ & 61.5 & 31.27 & 22.8 & 8.1 & 26.3 \\
\hline 300 & 13018300 & Cache Creek near Jackson, WY & 10.7 & $8,291.9$ & 75.7 & 34.72 & 40.3 & 21.0 & 71.2 \\
\hline 301 & 13019210 & Rim Draw near Bondurant, WY & 4.7 & $8,030.8$ & 94.9 & 26.96 & 26.5 & 7.6 & 38.8 \\
\hline 302 & 13019220 & Sour Moose Creek near Bondurant, WY & 2.8 & $7,773.4$ & 82.4 & 25.46 & 22.8 & 6.7 & 25.2 \\
\hline 303 & 13019400 & Cliff Creek near Bondurant, WY & 58.2 & $8,078.6$ & 71.6 & 28.09 & 35.1 & 17.7 & 55.5 \\
\hline
\end{tabular}


Table 4. Basin and climatic characteristics for streamflow-gaging stations in Idaho and bordering States used in regional regression analysis--Continued

\begin{tabular}{|c|c|c|c|c|c|c|c|c|c|}
\hline $\begin{array}{l}\text { Map } \\
\text { No. }\end{array}$ & $\begin{array}{c}\text { Gaging } \\
\text { station No. }\end{array}$ & Gaging station name & $\begin{array}{c}\text { DA } \\
\left(\mathrm{mi}^{2}\right) \\
\end{array}$ & $\begin{array}{c}E \\
(f t)\end{array}$ & $\begin{array}{c}\mathbf{F} \\
\text { (percent) }\end{array}$ & $\begin{array}{c}P \\
\text { (in.) } \\
\end{array}$ & $\begin{array}{c}\text { BS } \\
\text { (percent) }\end{array}$ & $\begin{array}{c}\text { NF30 } \\
\text { (percent) }\end{array}$ & $\begin{array}{c}\mathrm{S} 30 \\
\text { (percent) }\end{array}$ \\
\hline & & \multicolumn{8}{|c|}{ REGION 8--Continued } \\
\hline 304 & 13019438 & Little Granite Creek at mouth near Bondurant, WY & 82.7 & $8,559.5$ & 54.5 & 31.02 & 38.6 & 16.1 & 60.8 \\
\hline 305 & 13019500 & Hoback River near Jackson, WY & 561.3 & $7,961.5$ & 60.9 & 26.68 & 30.3 & 12.7 & 42.6 \\
\hline 306 & 13020000 & Fall Creek near Jackson, WY & 46.9 & $7,459.6$ & 65.6 & 28.89 & 32.7 & 18.4 & 50.5 \\
\hline 307 & 13021000 & Cabin Creek near Jackson, WY & 9.0 & $7,274.0$ & 72.5 & 23.64 & 35.6 & 26.5 & 64.7 \\
\hline 308 & 13022550 & Red Creek near Alpine, WY & 3.9 & $7,938.7$ & 38.8 & 30.63 & 53.6 & 7.7 & 88.7 \\
\hline 309 & 13023000 & Greys River above reservoir, near Alpine, WY & 448.8 & $8,105.3$ & 72.2 & 34.91 & 35.1 & 16.7 & 54.5 \\
\hline 310 & 13023800 & Fish Creek near Smoot, WY & 3.2 & $7,568.8$ & 68.8 & 27.87 & 18.7 & 3.2 & 11.9 \\
\hline 311 & 13024000 & Salt River near Smoot, WY & 48.2 & $8,010.1$ & 73.4 & 32.89 & 28.0 & 9.3 & 40.5 \\
\hline 312 & 13024500 & Cottonwood Creek near Smoot, WY & 25.7 & $8,647.5$ & 73.4 & 39.48 & 45.1 & 21.6 & 81.3 \\
\hline 313 & 13025000 & Swift Creek near Afton, WY & 27.7 & $8,496.0$ & 72.3 & 39.33 & 49.3 & 20.7 & 84.9 \\
\hline 314 & 13025500 & Crow Creek near Fairview, WY & 113.8 & $8,441.5$ & 34.5 & 29.44 & 24.9 & 9.9 & 33.2 \\
\hline 315 & 13027000 & Strawberry Creek near Bedford, WY & 20.1 & $8,469.4$ & 54.0 & 40.81 & 49.7 & 20.1 & 80.7 \\
\hline 316 & 13027200 & Bear Canyon near Freedom, WY & 3.3 & $7,087.4$ & 50.8 & 28.44 & 27.9 & 4.5 & 40.2 \\
\hline 317 & 13029500 & McCoy Creek above reservoir near Alpine, WY & 108.1 & $7,017.8$ & 59.3 & 26.69 & 27.5 & 12.4 & 40.4 \\
\hline 318 & 13030000 & Indian Creek above reservoir near Alpine, WY & 36.5 & $7,962.0$ & 46.8 & 31.08 & 51.5 & 25.2 & 83.1 \\
\hline 319 & 13030500 & Elk Creek above reservoir near Irwin, ID & 58.5 & $7,908.8$ & 59.5 & 34.15 & 49.8 & 26.6 & 81.4 \\
\hline 320 & 13032000 & Bear Creek above reservoir near Irwin, ID & 78.3 & $7,187.5$ & 56.1 & 26.74 & 38.8 & 22.6 & 69.7 \\
\hline 321 & 13038900 & Targhee Creek near Macks Inn, ID & 20.9 & $8,273.4$ & 57.8 & 30.06 & 34.6 & 11.8 & 49.3 \\
\hline 322 & 13044500 & Warm River at Warm River, ID & 131.1 & $6,675.6$ & 69.3 & 31.78 & 9.1 & 1.5 & 5.5 \\
\hline 323 & 13045500 & Robinson Creek at Warm River, ID & 123.7 & $6,418.3$ & 65.4 & 35.26 & 10.6 & 1.3 & 5.4 \\
\hline 324 & 13046680 & Boundary Creek near Bechler Ranger Station Y.N.P., ID & 85.4 & $7,912.5$ & 87.7 & 56.03 & 6.9 & 0.2 & 3.3 \\
\hline 325 & 13047500 & Falls River near Squirrel, ID & 333.6 & $7,540.3$ & 83.6 & 52.87 & 11.0 & 2.4 & 7.8 \\
\hline 326 & 13049500 & Falls River near Chester, ID & 512.9 & $6,974.2$ & 63.3 & 42.64 & 9.9 & 2.1 & 6.4 \\
\hline 327 & 13050700 & Mail Cabin Creek near Victor, ID & 3.0 & $8,287.6$ & 77.8 & 40.89 & 45.1 & 37.0 & 86.6 \\
\hline 328 & 13050800 & Moose Creek near Victor, ID & 21.8 & $8,499.6$ & 65.1 & 54.17 & 41.7 & 23.4 & 68.3 \\
\hline 329 & 13052200 & Teton River above South Leigh Creek, near Driggs, ID & 341.4 & $7,302.9$ & 39.7 & 31.73 & 23.6 & 13.3 & 34.5 \\
\hline 330 & 13054000 & Teton River near Tetonia, ID & 479.2 & $7,200.1$ & 38.2 & 30.33 & 21.5 & 11.5 & 30.0 \\
\hline 331 & 13054400 & Milk Creek near Tetonia, ID & 17.5 & $6,551.9$ & 15.7 & 16.55 & 9.2 & 0.4 & 1.8 \\
\hline 332 & 13055000 & Teton River near St. Anthony, ID & 874.8 & $6,920.9$ & 36.1 & 27.65 & 19.0 & 9.1 & 24.3 \\
\hline 333 & 13062700 & Angus Creek near Henry, ID & 14.3 & $6,881.2$ & 28.3 & 20.00 & 18.0 & 5.3 & 18.2 \\
\hline
\end{tabular}


Table 5. Peak flows at selected recurrence intervals for streamflow-gaging stations in Idaho and bordering States used in regional regression analysis

\begin{tabular}{|c|c|c|c|c|c|c|c|c|c|c|c|}
\hline \multirow{2}{*}{$\begin{array}{l}\text { Map } \\
\text { No. }\end{array}$} & \multirow{2}{*}{$\begin{array}{l}\text { Gaging } \\
\text { station }\end{array}$} & \multicolumn{7}{|c|}{$\begin{array}{l}\text { Peak flow, in cubic feet per second, for given } \\
\text { recurrence intervals, in years }\end{array}$} & \multirow[b]{2}{*}{500} & \multirow[b]{2}{*}{ Period of known peak flows } & \multirow{2}{*}{$\begin{array}{c}\text { Number } \\
\text { of years } \\
\text { of known } \\
\text { peak }\end{array}$} \\
\hline & & 2 & 5 & 10 & 25 & 50 & 100 & 200 & & & \\
\hline \multicolumn{12}{|c|}{ REGION 1} \\
\hline 1 & 12305500 & 1,240 & 1,720 & 2,050 & 2,470 & 2,800 & 3,130 & 3,470 & 3,930 & $1929-80$ & 50 \\
\hline 2 & 12309000 & 42 & 89 & 134 & 210 & 284 & 373 & 482 & 661 & $1928-31,33,35-38,74$ & 11 \\
\hline 3 & 12310800 & 154 & 241 & 317 & 439 & 550 & 682 & 838 & 1,090 & $1961-80$ & 19 \\
\hline 4 & 12311000 & 929 & 1,340 & 1,640 & 2,030 & 2,340 & 2,660 & 2,990 & 3,460 & $1928-74$ & 45 \\
\hline 5 & 12313500 & 524 & 886 & 1,180 & 1,630 & 2,020 & 2,460 & 2,950 & 3,710 & $1928-34,72-79$ & 15 \\
\hline 6 & 12316800 & 338 & 426 & 477 & 534 & 573 & 610 & 644 & 686 & $1959-81$ & 23 \\
\hline 7 & 12320500 & 602 & 797 & 930 & 1,100 & 1,230 & 1,370 & 1,500 & 1,690 & $1928-59$ & 32 \\
\hline 8 & 12321000 & 1,930 & 2,520 & 2,890 & 3,340 & 3,670 & 3,990 & 4,300 & 4,710 & $1928-71$ & 43 \\
\hline 9 & 12392100 & 42 & 99 & 162 & 285 & 419 & 601 & 847 & 1,300 & $1962-81$ & 20 \\
\hline 10 & 12392155 & 3,140 & 3,770 & 4,180 & 4,700 & 5,080 & 5,460 & 5,850 & 6,370 & $1989-99$ & 11 \\
\hline 11 & 12392300 & 2,580 & 3,490 & 4,160 & 5,060 & 5,790 & 6,550 & 7,370 & 8,540 & $1959-82$ & 24 \\
\hline 12 & 12392800 & 36 & 44 & 49 & 54 & 58 & 61 & 64 & 68 & $1961-71$ & 11 \\
\hline 13 & 12393500 & 4,830 & 6,110 & 6,840 & 7,660 & 8,200 & 8,700 & 9,160 & 9,730 & $1913-48$ & 35 \\
\hline 14 & 12393600 & 64 & 99 & 124 & 157 & 183 & 209 & 237 & 276 & $1962-71$ & 18 \\
\hline 15 & 12396000 & 506 & 814 & 1,070 & 1,450 & 1,780 & 2,150 & 2,580 & 3,230 & $1951-97$ & 47 \\
\hline 16 & 12408500 & 298 & 458 & 563 & 693 & 786 & 877 & 966 & 1,080 & $1940-86$ & 47 \\
\hline 17 & 12409000 & 1,150 & 1,850 & 2,320 & 2,890 & 3,300 & 3,700 & 4,080 & 4,570 & $1923-97$ & 75 \\
\hline 18 & 12427000 & 109 & 134 & 150 & 171 & 186 & 201 & 216 & 236 & $1949-79$ & 31 \\
\hline 19 & 12429600 & 137 & 192 & 234 & 291 & 338 & 388 & 443 & 521 & $1962-75$ & 14 \\
\hline 20 & 12430370 & 22 & 60 & 105 & 191 & 285 & 410 & 576 & 875 & $1950,62-75$ & 15 \\
\hline 21 & 12431000 & 1,290 & 1,970 & 2,460 & 3,100 & 3,590 & 4,090 & 4,610 & 5,320 & $1929-32,47-97$ & 55 \\
\hline \multicolumn{12}{|c|}{ REGION 2} \\
\hline 22 & 12302500 & 642 & 969 & 1,230 & 1,600 & 1,920 & 2,270 & 2,660 & 3,250 & $1933,37-44,48,54,59-69,74$ & 23 \\
\hline 23 & 12303100 & 226 & 319 & 385 & 474 & 544 & 617 & 693 & 801 & 1960-92 & 33 \\
\hline 24 & 12303500 & 2,170 & 3,070 & 3,720 & 4,620 & 5,340 & 6,100 & 6,920 & 8,080 & $1945-57,74,83-96$ & 28 \\
\hline 25 & 12304250 & 27 & 42 & 54 & 70 & 84 & 98 & 114 & 137 & $\begin{array}{c}1960-74 \\
1940\end{array}$ & $\begin{array}{l}20 \\
15\end{array}$ \\
\hline 26 & 12304300 & 128 & 183 & 225 & 286 & 337 & 393 & 455 & 547 & $1960-78$ & 19 \\
\hline 27 & 12304400 & 170 & 244 & 293 & 355 & 401 & 448 & 494 & 557 & $1960-74$ & 15 \\
\hline 28 & 12341000 & 1,270 & 1,670 & 1,900 & 2,170 & 2,360 & 2,540 & 2,700 & 2,910 & $1899,1948,58-59,61-64,66-67$ & 10 \\
\hline
\end{tabular}


Table 5. Peak flows at selected recurrence intervals for streamflow-gaging stations in Idaho and bordering States used in regional regression analysis--Continued

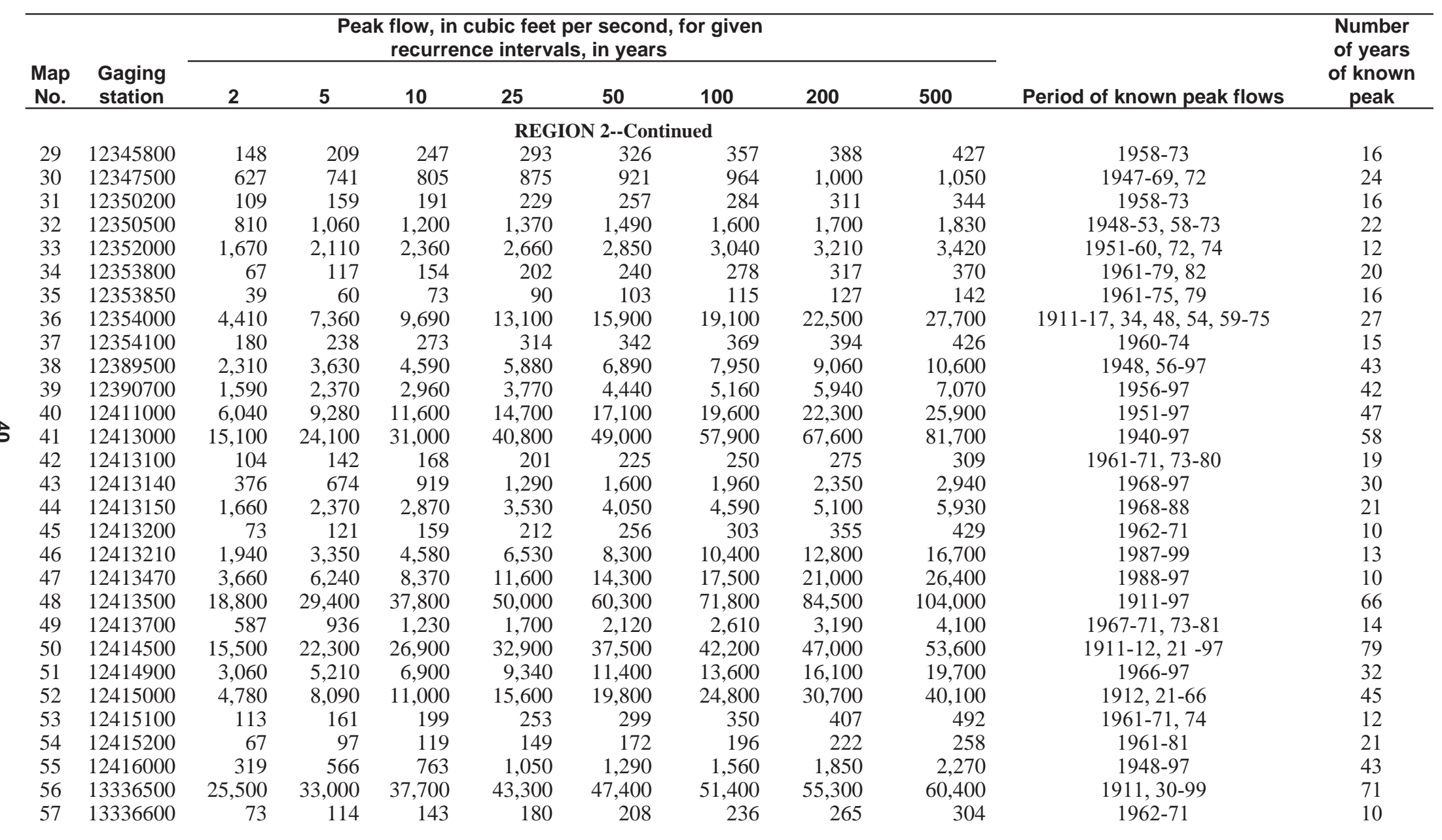


Table 5. Peak flows at selected recurrence intervals for streamflow-gaging stations in Idaho and bordering States used in regional regression analysis--Continued

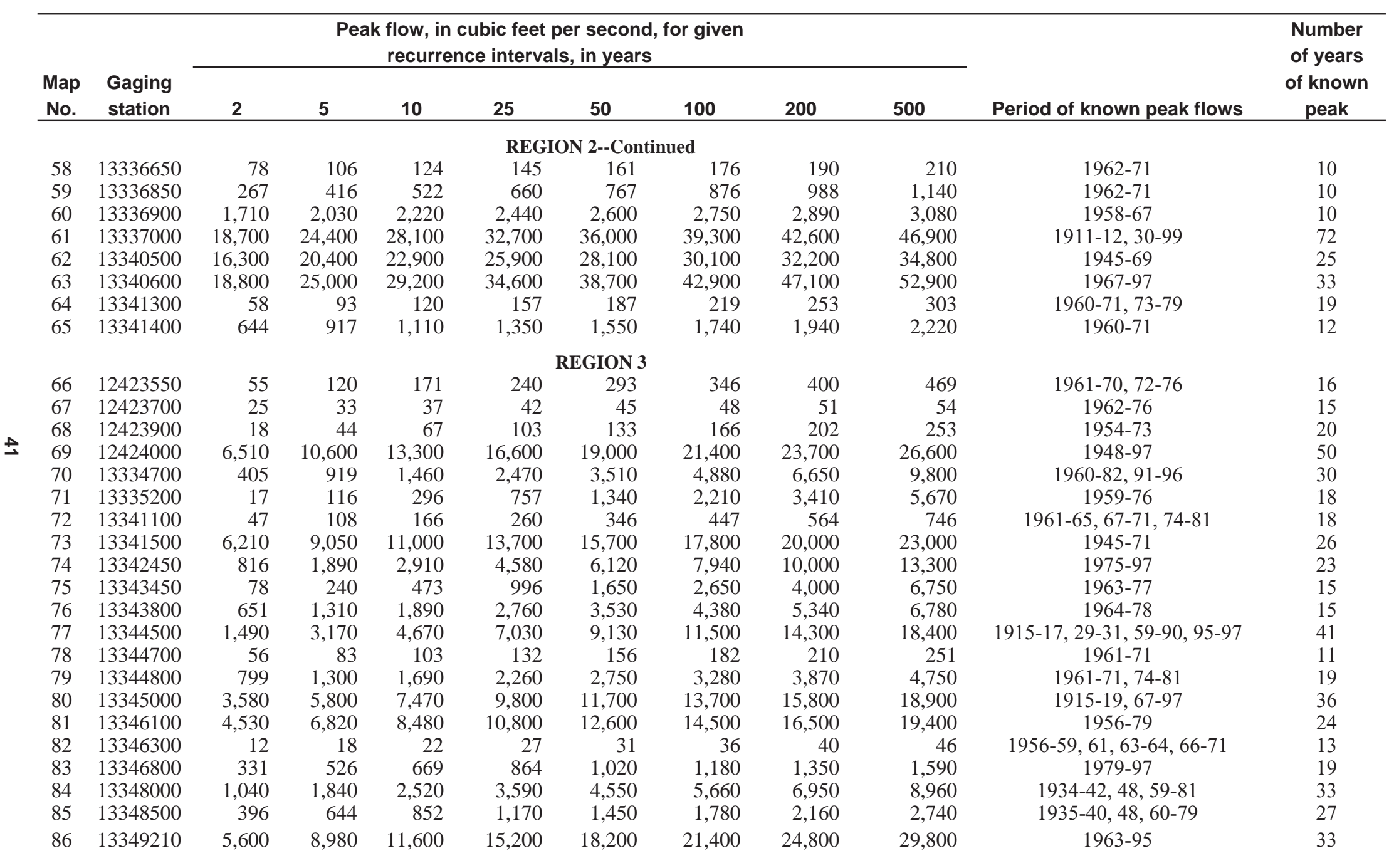


Table 5. Peak flows at selected recurrence intervals for streamflow-gaging stations in Idaho and bordering States used in regional regression analysis--Continued

\begin{tabular}{|c|c|c|c|c|c|c|c|c|c|c|c|}
\hline \multirow[b]{2}{*}{$\begin{array}{l}\text { Map } \\
\text { No. }\end{array}$} & \multirow[b]{2}{*}{$\begin{array}{l}\text { Gaging } \\
\text { station }\end{array}$} & \multicolumn{7}{|c|}{$\begin{array}{l}\text { Peak flow, in cubic feet per second, for given } \\
\text { recurrence intervals, in years }\end{array}$} & \multirow[b]{2}{*}{500} & \multirow[b]{2}{*}{ Period of known peak flows } & \multirow{2}{*}{$\begin{array}{c}\text { Number } \\
\text { of years } \\
\text { of known } \\
\text { peak }\end{array}$} \\
\hline & & 2 & 5 & 10 & 25 & 50 & 100 & 200 & & & \\
\hline \multicolumn{12}{|c|}{ REGION 3--Continued } \\
\hline 87 & 13349400 & 1,840 & 3.680 & 5,350 & 8.040 & 10,500 & 13,500 & 16,900 & 22.300 & $1962-79$ & 18 \\
\hline 88 & 13350500 & 865 & 1.540 & 2.090 & 2.890 & 3,570 & 4,320 & 5,150 & 6,380 & $1954-79$ & 26 \\
\hline 89 & 14016000 & 522 & 1,080 & 1,560 & 2,310 & 2,970 & 3,720 & 4,560 & 5,820 & $1949-53,55-67$ & 18 \\
\hline 90 & 14016500 & 858 & 1,500 & 2,050 & 2,910 & 3,670 & 4,560 & 5,590 & 7,200 & $1944-51,56-68$ & 21 \\
\hline 91 & 14017000 & 2,770 & 4,430 & 5,660 & 7,380 & 8,760 & 10,200 & 11,800 & 14,100 & $1906-89$ & 84 \\
\hline \multicolumn{11}{|c|}{ REGION 4} & \\
\hline 92 & 13185500 & 91 & 191 & 283 & 431 & 567 & 727 & 914 & 1,210 & $1914-18,39-43,55$ & 11 \\
\hline 93 & 13196500 & 13 & 24 & 34 & 47 & 59 & 72 & 87 & 108 & $1939-41,51-71$ & 24 \\
\hline 94 & 13200000 & 1,650 & 2,880 & 3,790 & 5,020 & 5,980 & 6,970 & 7,980 & 9,380 & 1951-97 & 47 \\
\hline 95 & 13200500 & 62 & 110 & 148 & 205 & 253 & 306 & 365 & 453 & $1951-71$ & 21 \\
\hline 96 & 13201000 & 1,930 & 3,080 & 3,930 & 5,080 & 5,990 & 6,950 & 7,950 & 9,360 & $1916-54$ & 39 \\
\hline 97 & 13207000 & 51 & 129 & 207 & 341 & 469 & 622 & 805 & 1,100 & $1955-59,61-71$ & 16 \\
\hline 98 & 13207500 & 94 & 237 & 384 & 640 & 890 & 1,190 & 1,560 & 2,160 & $1955-68$ & 14 \\
\hline 99 & 13216500 & 882 & 1,620 & 2,240 & 3,170 & 3,960 & 4,850 & 5,830 & 7,310 & $1904-82,84-94$ & 90 \\
\hline 100 & 13248900 & 78 & 136 & 185 & 262 & 332 & 413 & 508 & 658 & $1961-71,73-80$ & 19 \\
\hline 101 & 13250600 & 938 & 1,430 & 1,770 & 2,210 & 2,550 & 2,900 & 3,250 & 3,720 & $1957,62-82,97$ & 23 \\
\hline 102 & 13250650 & 92 & 233 & 359 & 548 & 706 & 875 & 1,050 & 1,300 & $1962-71$ & 10 \\
\hline 103 & 13251300 & 39 & 58 & 73 & 92 & 107 & 123 & 139 & 163 & $1960-77$ & 18 \\
\hline 104 & 13251500 & 484 & 720 & 884 & 1,100 & 1,270 & 1,440 & 1,620 & 1,860 & $1937-71,74-75,97$ & 38 \\
\hline 105 & 13252500 & $\begin{array}{r}+04 \\
55\end{array}$ & 65 & $\begin{array}{r}004 \\
71\end{array}$ & 78 & 82 & $\begin{array}{r}1,+40 \\
86\end{array}$ & $\begin{array}{r}1,0<0 \\
90\end{array}$ & $\begin{array}{r}1,000 \\
95\end{array}$ & $1933-35,37-43$ & 10 \\
\hline 106 & 13253500 & 991 & 1,540 & 1,940 & 2,490 & 2,920 & 3,380 & 3,870 & 4,555 & $1939-49,56$ & 12 \\
\hline 107 & 13256000 & 2,910 & 4,290 & 5,260 & 6,550 & 7,550 & 8,590 & 9,660 & 11,200 & $1937-41,43-53,56$ & 17 \\
\hline 108 & 13257000 & 817 & 1,210 & 1,480 & 1,840 & 2,110 & 2,390 & 2,670 & 3,060 & $\begin{array}{c}1911-13,20-21,37-49,56 \\
81-82,85-88,97\end{array}$ & 26 \\
\hline 109 & 13258500 & 4,770 & 7,090 & 8,590 & 10,400 & 11,700 & 13,000 & 14,300 & 15,900 & $1939-97$ & 59 \\
\hline 110 & 13260000 & 266 & 430 & 560 & 750 & 910 & 1,090 & 1,280 & 1,570 & $1939-62,97$ & 25 \\
\hline 111 & 13261000 & 729 & 1,070 & 1,320 & 1,650 & 1,910 & 2,180 & 2,460 & 2,860 & $1923-27,38-71,97$ & 40 \\
\hline 112 & 13266000 & 9,720 & 15,200 & 19,000 & 23,600 & 27,100 & 30,500 & 33,800 & 38,200 & $1890-91,1895-1904,11-14,53-97$ & 61 \\
\hline 113 & 13267000 & 420 & 655 & 831 & 1,080 & 1,270 & 1,490 & 1,710 & 2,040 & $1911-13,19337-65$ & 32 \\
\hline 114 & 13267100 & 67 & 106 & 135 & 175 & 208 & 243 & 281 & 334 & $1962-71$ & 10 \\
\hline 115 & 13269300 & 686 & 931 & 1,080 & 1,260 & 1,390 & 1,520 & 1,640 & 1,790 & $1967-80$ & 16 \\
\hline 116 & 13270800 & 73 & 108 & 131 & 162 & 185 & 208 & 231 & 263 & $1964-81$ & 18 \\
\hline 117 & 13275500 & 708 & 1,060 & 1,290 & 1,570 & 1,780 & 1,980 & 2,170 & 2,430 & $1904-16,20-25,27-68$ & 61 \\
\hline 118 & 13288200 & 2,020 & 2,700 & 3,150 & 3,750 & 4,200 & 4,660 & 5,140 & 5,800 & $1958-97$ & 40 \\
\hline
\end{tabular}


Table 5. Peak flows at selected recurrence intervals for streamflow-gaging stations in Idaho and bordering States used in regional regression analysis--Continued

\begin{tabular}{|c|c|c|c|c|c|c|c|c|c|c|c|}
\hline \multirow{2}{*}{$\begin{array}{l}\text { Map } \\
\text { No. }\end{array}$} & \multirow{2}{*}{$\begin{array}{l}\text { Gaging } \\
\text { station }\end{array}$} & \multicolumn{8}{|c|}{$\begin{array}{l}\text { Peak flow, in cubic feet per second, for given } \\
\text { recurrence intervals, in years }\end{array}$} & \multirow[b]{2}{*}{ Period of known peak flows } & \multirow{2}{*}{$\begin{array}{c}\text { Number } \\
\text { of years } \\
\text { of known } \\
\text { peak }\end{array}$} \\
\hline & & 2 & 5 & 10 & 25 & 50 & 100 & 200 & 500 & & \\
\hline \multicolumn{12}{|c|}{ REGION 4--Continued } \\
\hline 119 & 13289100 & 89 & 137 & 169 & 211 & 242 & 273 & 303 & 345 & $1964-65,67-81$ & 17 \\
\hline 120 & 13289600 & 91 & 167 & 226 & 311 & 380 & 454 & 532 & 642 & $1962-71$ & 10 \\
\hline 121 & 13289960 & 903 & 1,530 & 2,030 & 2,740 & 3,340 & 3,990 & 4,700 & 5,750 & $1979-96$ & 18 \\
\hline 122 & 13290190 & 2,570 & 4,140 & 5,310 & 6,920 & 8,210 & 9,570 & 11,000 & 13,000 & $1967-96$ & 30 \\
\hline 123 & 13291000 & 1,640 & 1,960 & 2,150 & 2,400 & 2,580 & 2,750 & 2,930 & 3,160 & $1945-53$ & 9 \\
\hline 124 & 13291200 & 72 & 103 & 123 & 150 & 169 & 189 & 209 & 236 & $1965-75$ & 11 \\
\hline 125 & 13315500 & 199 & 280 & 334 & 402 & 453 & 505 & 557 & 626 & $1937-38,46-59,62-71$ & 26 \\
\hline 126 & 13316500 & 4,900 & 6,710 & 7,900 & 9,390 & 10,500 & 11,600 & 12,700 & 14,100 & $1948,51-99$ & 48 \\
\hline 127 & 13316800 & 138 & 218 & 282 & 373 & 449 & 533 & 625 & 761 & $1960-71$ & 12 \\
\hline 128 & 13317000 & 61,600 & 83,000 & 95,600 & 110,000 & 120,000 & 129,000 & 137,000 & 148,000 & $1894,1911-99$ & 88 \\
\hline 129 & 13317200 & 98 & 208 & 309 & 468 & 612 & 779 & 970 & 1,270 & $1961-72$ & 12 \\
\hline 130 & 13319000 & 3,260 & 4,860 & 6,020 & 7,580 & 8,810 & 10,100 & 11,400 & 13,300 & $1904-09,11-15,18-23,26-89$ & 81 \\
\hline 131 & 13320000 & 749 & 1,010 & 1,170 & 1,360 & 1,500 & 1,630 & 1,760 & 1,930 & $1912,15,18-19,26,97$ & 75 \\
\hline 132 & 13323600 & 405 & 545 & 637 & 753 & 840 & 926 & 1,010 & 1,130 & $1938-50$ & 13 \\
\hline 133 & 13329500 & 540 & 735 & 859 & 1,010 & 1,120 & 1,230 & 1,330 & 1,470 & $1915,24-78$ & 56 \\
\hline 134 & 13330000 & 1,580 & 1,930 & 2,140 & 2,390 & 2,570 & 2,740 & 2,900 & 3,110 & $1913,26-91,95-97$ & 70 \\
\hline 135 & 13330500 & 923 & 1,220 & 1,400 & 1,630 & 1,800 & 1,960 & 2,120 & 2,330 & $1915,24-85,95-97$ & 66 \\
\hline 136 & 13331500 & 3,110 & 4,090 & 4,730 & 5,530 & 6,120 & 6,700 & 7,290 & 8,080 & $1913,66-97$ & 33 \\
\hline 137 & 13337200 & 90 & 140 & 176 & 224 & 261 & 299 & 338 & 392 & $1962-71$ & 10 \\
\hline 138 & 13337500 & 1,930 & 2,600 & 3,060 & 3,650 & 4,100 & 4,560 & 5,030 & 5,680 & $1945-74$ & 30 \\
\hline 139 & 13337700 & 91 & 134 & 166 & 208 & 242 & 277 & 315 & 367 & $1962-81$ & 16 \\
\hline 140 & 13338000 & 5,000 & 6,770 & 8,030 & 9,700 & 11,000 & 12,400 & 13,800 & 15,900 & $1911-20,23-63$ & 51 \\
\hline 141 & 13338200 & 186 & 249 & 291 & 341 & 378 & 415 & 451 & 499 & $1961-71$ & 11 \\
\hline 142 & 13338500 & 6,560 & 9,620 & 11,700 & 14,300 & 16,300 & 18,300 & 20,300 & 22,900 & 1964-99 & 36 \\
\hline 143 & 13339000 & 53,000 & 67,800 & 76,800 & 87,400 & 94,900 & 102,000 & 109,000 & 118,000 & $1911-65$ & 55 \\
\hline 144 & 13339500 & 2,140 & 3,260 & 4,030 & 5,050 & 5,830 & 6,610 & 7,420 & 8,510 & 1980-99 & 20 \\
\hline 145 & 13339700 & 123 & 174 & 207 & 251 & 283 & 316 & 349 & 394 & $1962-81$ & 19 \\
\hline 146 & 13339900 & 109 & 228 & 336 & 507 & 660 & 837 & 1,040 & 1,350 & $1962-71,74-81$ & 18 \\
\hline 147 & 13340000 & 54,200 & 69,100 & 78,100 & 88,500 & 95,800 & 103,000 & 109,000 & 118,000 & $1931-33,35-38,65-99$ & 42 \\
\hline 148 & 14010000 & 776 & 1,180 & 1,510 & 1,970 & 2,370 & 2,810 & 3,300 & 4,040 & $1903,07,09-16,32-91$ & 70 \\
\hline 149 & 14011000 & 489 & 812 & 1,080 & 1,490 & 1,840 & 2,250 & 2,710 & 3,420 & $1930,33-69$ & 38 \\
\hline 150 & 14013000 & 890 & 1,550 & 2,120 & 3,010 & 3,810 & 4,740 & 5,830 & 7,540 & $1914-17,40-97$ & 62 \\
\hline 151 & 14013500 & 317 & 548 & 730 & 991 & 1,210 & 1,440 & 1,700 & 2,070 & $1940-42,44-71$ & 31 \\
\hline
\end{tabular}


Table 5. Peak flows at selected recurrence intervals for streamflow-gaging stations in Idaho and bordering States used in regional regression analysis--Continued

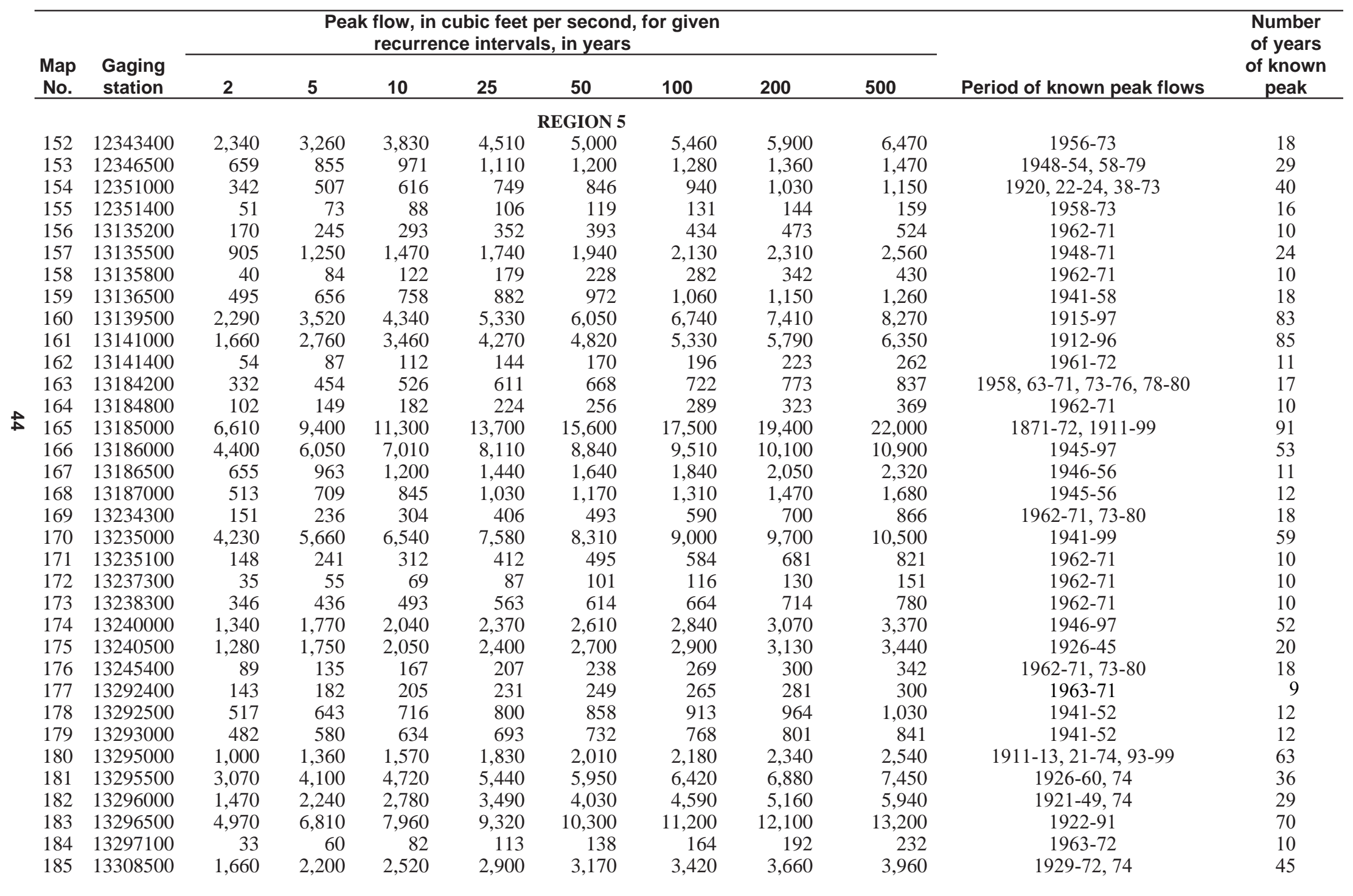


Table 5. Peak flows at selected recurrence intervals for streamflow-gaging stations in Idaho and bordering States used in regional regression analysis--Continued

\begin{tabular}{|c|c|c|c|c|c|c|c|c|c|c|c|}
\hline \multirow{2}{*}{$\begin{array}{l}\text { Map } \\
\text { No. }\end{array}$} & \multirow{2}{*}{$\begin{array}{l}\text { Gaging } \\
\text { station }\end{array}$} & \multicolumn{7}{|c|}{$\begin{array}{l}\text { Peak flow, in cubic feet per second, for given } \\
\text { recurrence intervals, in years }\end{array}$} & \multirow[b]{2}{*}{500} & \multirow[b]{2}{*}{ Period of known peak flows } & \multirow{2}{*}{$\begin{array}{c}\text { Number } \\
\text { of years } \\
\text { of known } \\
\text { peak }\end{array}$} \\
\hline & & 2 & 5 & 10 & 25 & 50 & 100 & 200 & & & \\
\hline \multicolumn{12}{|c|}{ REGION 5--Continued } \\
\hline 186 & 13309000 & 2,110 & 2,810 & 3,240 & 3,740 & 4,080 & 4,410 & 4,720 & 5,110 & $1922-60$ & 39 \\
\hline 187 & 13309220 & 8,870 & 12,600 & 15,100 & 18,300 & 20,600 & 23,000 & 25,400 & 28,500 & $1973-81$ & 9 \\
\hline 188 & 13310000 & 3,780 & 4,780 & 5,340 & 5,940 & 6,340 & 6,700 & 7,020 & 7,410 & $1945-58$ & 14 \\
\hline 189 & 13310500 & 1,030 & 1,330 & 1,510 & 1,710 & 1,850 & 1,980 & 2,110 & 2,270 & $1929,31-60$ & 31 \\
\hline 190 & 13310700 & 3,330 & 4,620 & 5,450 & 6,460 & 7,200 & 7,920 & 8,620 & 9,550 & 1967-99 & 29 \\
\hline 191 & 13311000 & 173 & 250 & 302 & 368 & 417 & 466 & 516 & 583 & $1929-42,83-97$ & 29 \\
\hline 192 & 13311500 & 352 & 499 & 594 & 713 & 800 & 886 & 971 & 1,080 & $1929-40$ & 12 \\
\hline 193 & 13312000 & 953 & 1,270 & 1,470 & 1,720 & 1,910 & 2,090 & 2,270 & 2,510 & $1929-43$ & 15 \\
\hline 194 & 13313000 & 2,930 & 3,930 & 4,540 & 5,280 & 5,810 & 6,320 & 6,810 & 7,440 & $1929-99$ & 71 \\
\hline 195 & 13313500 & 1,400 & 1,780 & 2,010 & 2,280 & 2,470 & 2,650 & 2,830 & 3,050 & $1943-52$ & 10 \\
\hline 196 & 13314000 & 11,400 & 15,100 & 17,500 & 20,400 & 22,600 & 24,800 & 26,900 & 29,800 & $1932-48$ & 13 \\
\hline 197 & 13315000 & 61,500 & 75,100 & 82,600 & 91,000 & 96,500 & 101,000 & 106,000 & 112,000 & $1945-56$ & 12 \\
\hline \multicolumn{11}{|c|}{ REGION 6} & \\
\hline 198 & 06013500 & 331 & 517 & 647 & 818 & 948 & 1,080 & 1,220 & 1,400 & $1946-53,60-91$ & 40 \\
\hline 199 & 06015500 & 393 & 681 & 890 & 1,170 & 1,380 & 1,590 & 1,810 & 2,100 & $1921-32,46-53,55-58,60-73,75$ & 39 \\
\hline 200 & 06019500 & 968 & 1,350 & 1,630 & 1,990 & 2,270 & 2,570 & 2,880 & 3,310 & 1939-97 & 59 \\
\hline 201 & 13108500 & 808 & 1,310 & 1,680 & 2,180 & 2,580 & 2,990 & 3,420 & 4,020 & $1937-53,69-73$ & 22 \\
\hline 202 & 13112000 & 454 & 768 & 980 & 1,240 & 1,430 & 1,610 & 1,790 & 2,010 & $1925-97$ & 73 \\
\hline 203 & 13112900 & 9.8 & 17 & 23 & 32 & 39 & 47 & 55 & 66 & $1962-71$ & 10 \\
\hline 204 & 13113000 & 307 & 516 & 670 & 880 & 1,040 & 1,220 & 1,390 & 1,640 & $1941-52,69-93$ & 35 \\
\hline 205 & 13113500 & 264 & 454 & 597 & 792 & 947 & 1,110 & 1,280 & 1,510 & $1921-73,83-87$ & 57 \\
\hline 206 & 13117200 & 135 & 197 & 237 & 285 & 319 & 351 & 383 & 423 & $1962-71$ & 10 \\
\hline 207 & 13117300 & 379 & 522 & 611 & 717 & 793 & 866 & 937 & 1,030 & $1961-73$ & 13 \\
\hline 208 & 13120000 & 742 & 1,060 & 1,260 & 1,510 & 1,680 & 1,850 & 2,020 & 2,230 & $1944-97$ & 54 \\
\hline 209 & 13120500 & 2,150 & 3,000 & 3,490 & 4,050 & 4,430 & 4,780 & 5,100 & 5,490 & $1904-14,20-97$ & 89 \\
\hline 210 & 13128900 & 183 & 228 & 254 & 286 & 308 & 330 & 350 & 377 & $1963-73,80-84$ & 16 \\
\hline 211 & 13297300 & 8.9 & 15 & 20 & 26 & 32 & 37 & 43 & 51 & $1963-71,74$ & 10 \\
\hline 212 & 13297330 & 123 & 240 & 332 & 461 & 565 & 675 & 790 & 950 & $1973-97$ & 25 \\
\hline 213 & 13297350 & 7.4 & 19 & 29 & 45 & 59 & 74 & 90 & 113 & $1971-97$ & 27 \\
\hline 214 & 13297355 & 252 & 469 & 630 & 845 & 1,010 & 1,180 & 1,340 & 1,570 & $1973-97$ & 25 \\
\hline 215 & 13297450 & 206 & 323 & 405 & 511 & 591 & 671 & 753 & 863 & $1970-86$ & 17 \\
\hline 216 & 13298000 & 1,590 & 2,330 & 2,810 & 3,400 & 3,820 & 4,230 & 4,630 & 5,140 & $1929-38,73-81$ & 19 \\
\hline 217 & 13298300 & 85 & 245 & 422 & 744 & 1,070 & 1,480 & 1,980 & 2,820 & $1962-71$ & 10 \\
\hline 218 & 13299000 & 246 & 347 & 413 & 497 & 559 & 621 & 683 & 766 & $1944-63$ & 20 \\
\hline 219 & 13301700 & 147 & 206 & 243 & 288 & 321 & 353 & 384 & 424 & $1962-71,73-76,78-80$ & 17 \\
\hline
\end{tabular}


Table 5. Peak flows at selected recurrence intervals for streamflow-gaging stations in Idaho and bordering States used in regional regression analysis--Continued

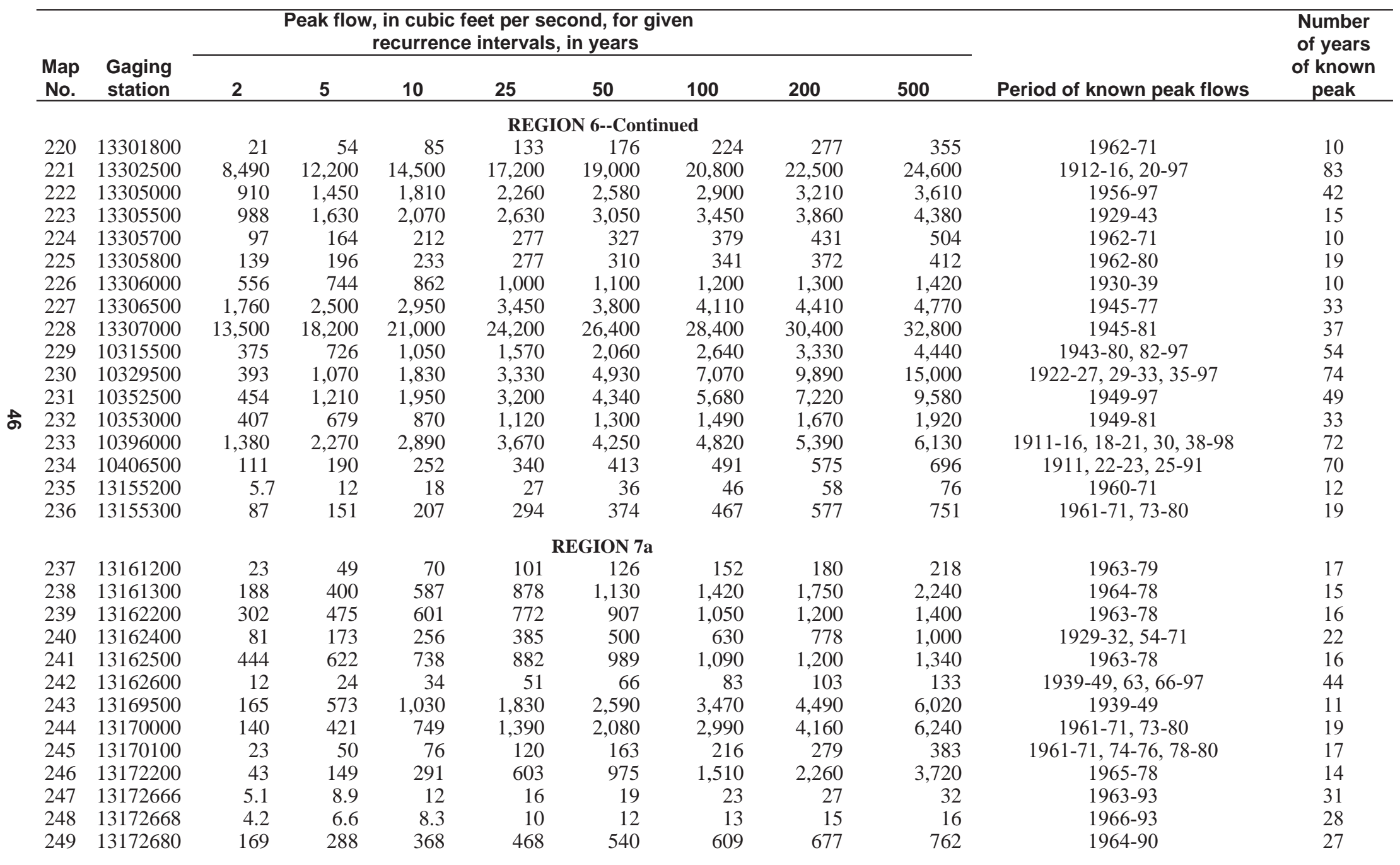


Table 5. Peak flows at selected recurrence intervals for streamflow-gaging stations in Idaho and bordering States used in regional regression analysis--Continued

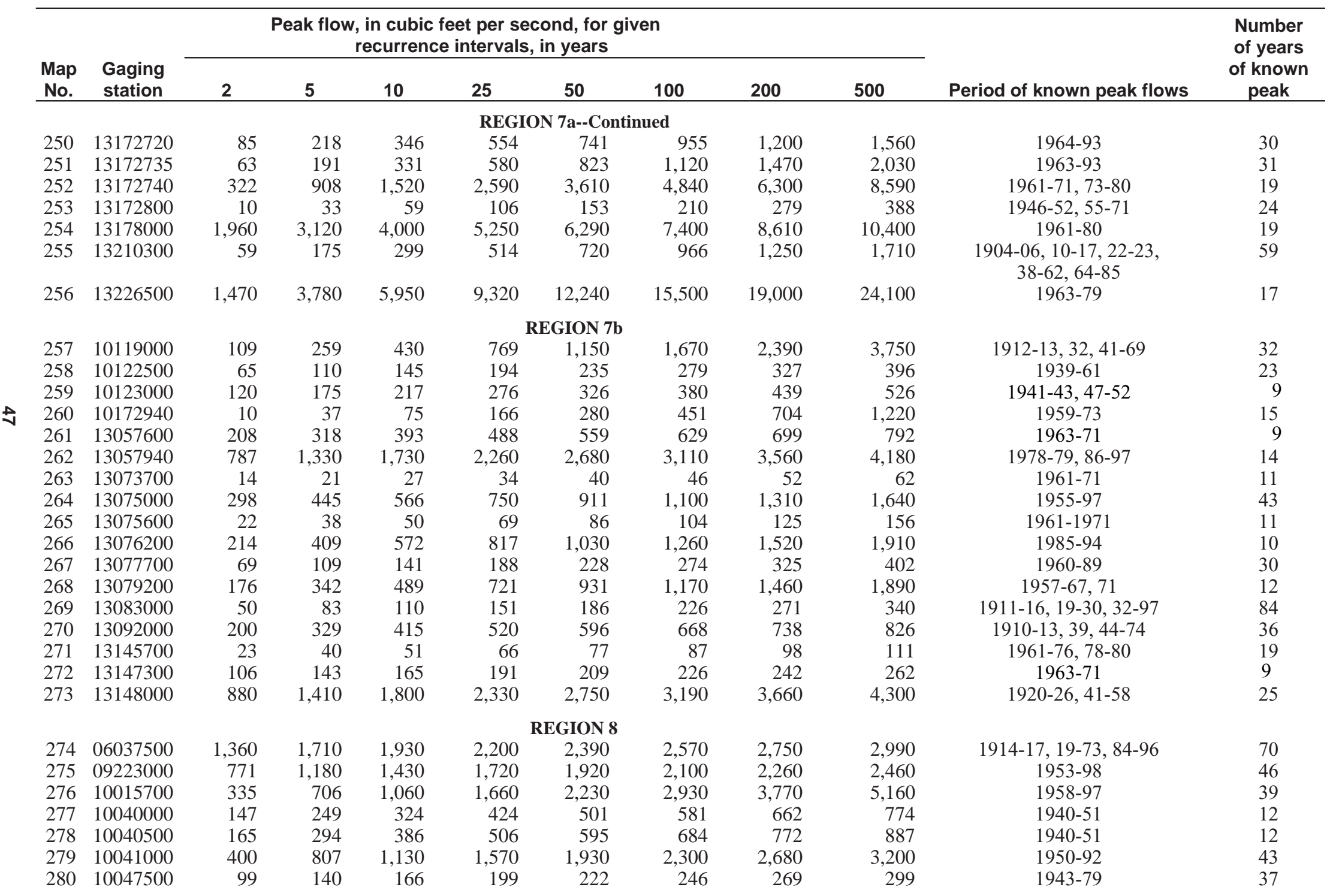


Table 5. Peak flows at selected recurrence intervals for streamflow-gaging stations in Idaho and bordering States used in regional regression analysis--Continued

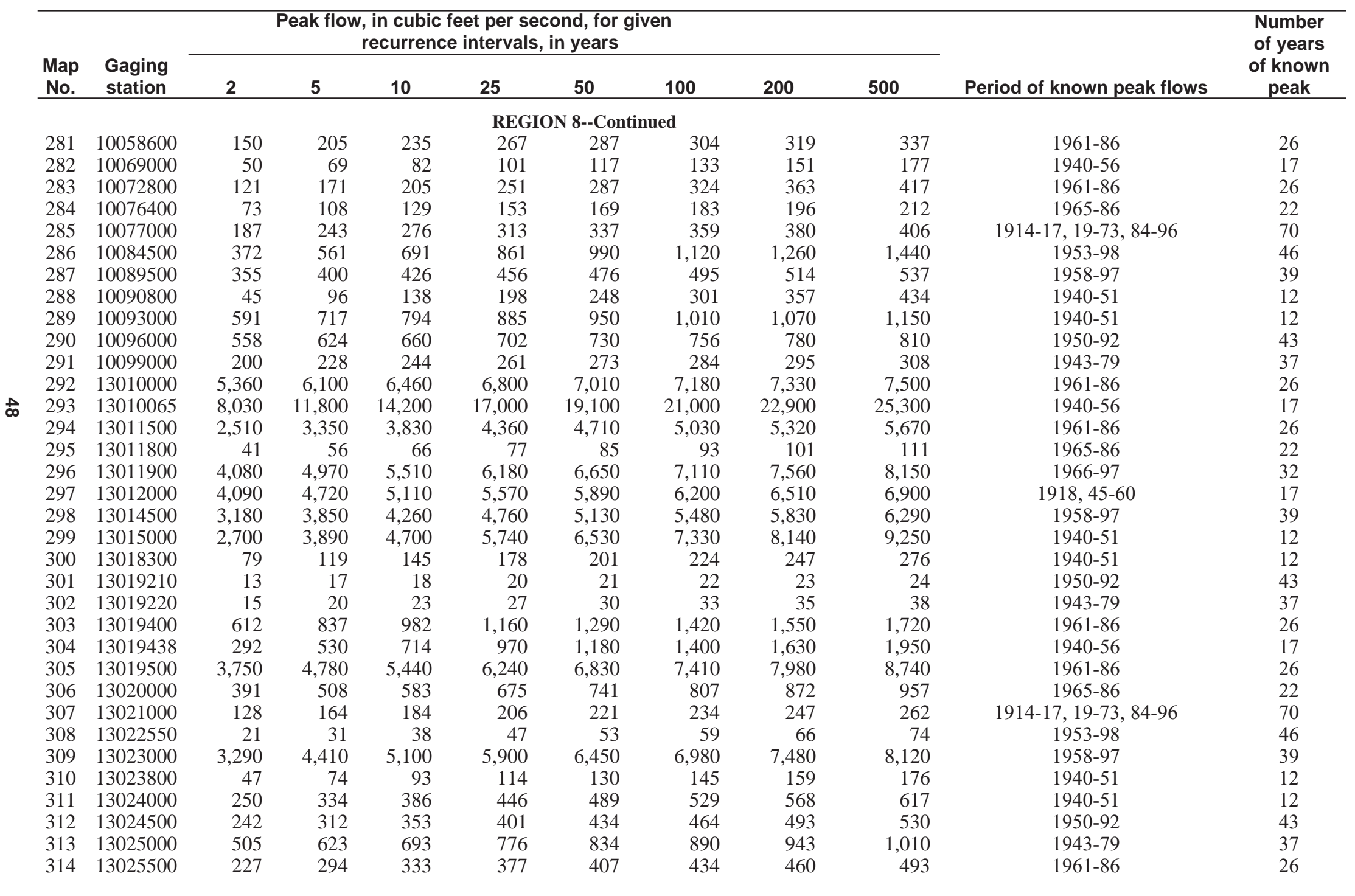


Table 5. Peak flows at selected recurrence intervals for streamflow-gaging stations in Idaho and bordering States used in regional regression analysis--Continued

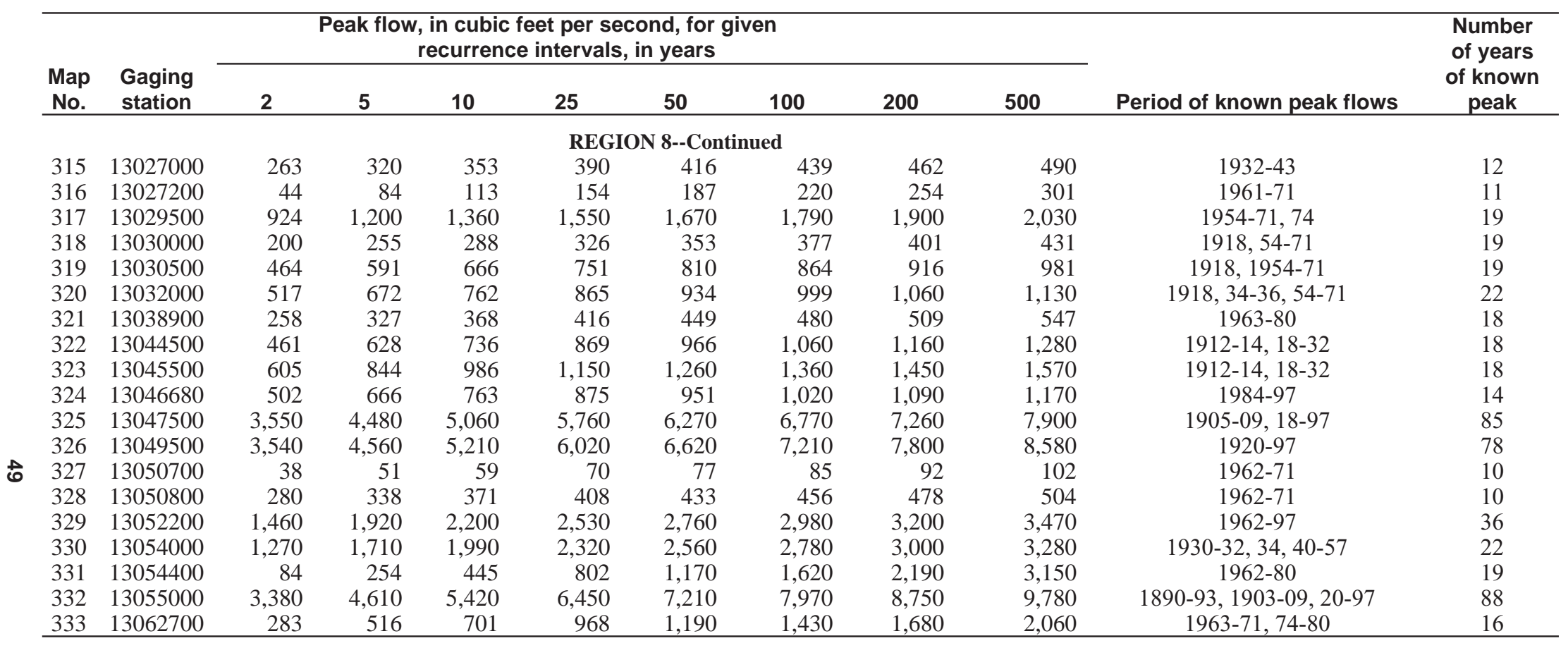


Table 9. $\left(X^{\top} \Lambda^{-1} X\right)^{-1}$ matrices for the $T-y e a r(T=2,5,10,25,50,100,200$, and 500$)$ regional regression equations for Idaho

[Some numbers are in scientific notation; DA, drainage area; E, mean basin elevation; F, percentage of forest cover in the basin; P, mean annual precipitation; NF30, percentage of north-facing slopes greater than 30 percent; BS, average basin slope; S30, percentage of slopes greater than 30 percent]

\begin{tabular}{|c|c|c|c|}
\hline \multicolumn{4}{|c|}{$\left(X^{\top} \Lambda^{-1} X\right)^{-1}$ matrix } \\
\hline \multicolumn{4}{|c|}{ REGION 1} \\
\hline CONSTANT & DA & $\mathbf{E}$ & $\mathbf{F}$ \\
\hline \multicolumn{4}{|c|}{ 2-year recurrence interval } \\
\hline 0.70947 & $-0.13937 \mathrm{E}-01$ & $0.74767 \mathrm{E}-01$ & -0.38336 \\
\hline$-0.13937 \mathrm{E}-01$ & $0.50165 \mathrm{E}-02$ & $0.20736 \mathrm{E}-02$ & $0.22620 \mathrm{E}-02$ \\
\hline $0.74767 \mathrm{E}-01$ & $0.20736 \mathrm{E}-02$ & 0.26166 & -0.11881 \\
\hline-0.38336 & $0.22620 \mathrm{E}-02$ & -0.11881 & 0.23590 \\
\hline \multicolumn{4}{|c|}{ 5-year recurrence interval } \\
\hline 0.56929 & $-0.13099 \mathrm{E}-01$ & $0.42010 \mathrm{E}-01$ & -0.29924 \\
\hline$-0.13099 \mathrm{E}-01$ & $0.36470 \mathrm{E}-02$ & $0.19558 \mathrm{E}-02$ & $0.29579 \mathrm{E}-02$ \\
\hline $0.42010 \mathrm{E}-01$ & $0.19558 \mathrm{E}-02$ & 0.18097 & $-0.77605 \mathrm{E}-01$ \\
\hline-0.29924 & $0.29579 \mathrm{E}-02$ & $-0.77605 \mathrm{E}-01$ & 0.17800 \\
\hline \multicolumn{4}{|c|}{ 10-year recurrence interval } \\
\hline 0.58339 & $-0.14658 \mathrm{E}-01$ & $0.30779 \mathrm{E}-01$ & -0.30104 \\
\hline$-0.14658 \mathrm{E}-01$ & $0.34412 \mathrm{E}-02$ & $0.21476 \mathrm{E}-02$ & $0.38258 \mathrm{E}-02$ \\
\hline $0.30779 \mathrm{E}-01$ & $0.21476 \mathrm{E}-02$ & 0.16433 & $-0.66963 \mathrm{E}-01$ \\
\hline-0.30104 & $0.38258 \mathrm{E}-02$ & $-0.66963 \mathrm{E}-01$ & 0.17462 \\
\hline \multicolumn{4}{|c|}{ 25-year recurrence interval } \\
\hline 0.67266 & $-0.18001 \mathrm{E}-01$ & $0.24555 \mathrm{E}-01$ & -0.34210 \\
\hline$-0.18001 \mathrm{E}-01$ & $0.36737 \mathrm{E}-02$ & $0.25408 \mathrm{E}-02$ & $0.51651 \mathrm{E}-02$ \\
\hline $0.24555 \mathrm{E}-01$ & $0.25408 \mathrm{E}-02$ & 0.16945 & $-0.65577 \mathrm{E}-01$ \\
\hline-0.34210 & $0.51651 \mathrm{E}-02$ & $-0.65577 \mathrm{E}-01$ & 0.19420 \\
\hline \multicolumn{4}{|c|}{ 50-year recurrence interval } \\
\hline 0.77568 & $-0.21203 E-01$ & $0.23830 \mathrm{E}-01$ & -0.39246 \\
\hline$-0.21203 \mathrm{E}-01$ & $0.40965 \mathrm{E}-02$ & $0.29094 \mathrm{E}-02$ & $0.62941 \mathrm{E}-02$ \\
\hline $0.23830 \mathrm{E}-01$ & $0.29094 \mathrm{E}-02$ & 0.18638 & $-0.70549 \mathrm{E}-01$ \\
\hline-0.39246 & $0.62941 E-02$ & $-0.70549 \mathrm{E}-01$ & 0.22091 \\
\hline \multicolumn{4}{|c|}{ 100-year recurrence interval } \\
\hline 0.90234 & $-0.24874 \mathrm{E}-01$ & $0.25410 \mathrm{E}-01$ & -0.45552 \\
\hline$-0.24874 \mathrm{E}-01$ & $0.46760 \mathrm{E}-02$ & $0.33256 \mathrm{E}-02$ & $0.75159 \mathrm{E}-02$ \\
\hline $0.25410 \mathrm{E}-01$ & $0.33256 \mathrm{E}-02$ & 0.21144 & $-0.79177 \mathrm{E}-01$ \\
\hline-0.45552 & $0.75159 \mathrm{E}-02$ & $-0.79177 \mathrm{E}-01$ & 0.25532 \\
\hline \multicolumn{4}{|c|}{ 200-year recurrence interval } \\
\hline 1.0492 & $-0.28955 \mathrm{E}-01$ & $0.28796 \mathrm{E}-01$ & -0.52941 \\
\hline$-0.28955 \mathrm{E}-01$ & $0.53858 \mathrm{E}-02$ & $0.37810 \mathrm{E}-02$ & $0.88248 \mathrm{E}-02$ \\
\hline $0.28796 \mathrm{E}-01$ & $0.37810 \mathrm{E}-02$ & 0.24315 & $-0.90760 \mathrm{E}-01$ \\
\hline-0.52941 & $0.88248 \mathrm{E}-02$ & $-0.90760 \mathrm{E}-01$ & 0.29625 \\
\hline \multicolumn{4}{|c|}{ 500-year recurrence interval } \\
\hline 1.2708 & $-0.34905 E-01$ & $0.35617 \mathrm{E}-01$ & -0.64167 \\
\hline$-0.34905 \mathrm{E}-01$ & $0.64979 \mathrm{E}-02$ & $0.44322 \mathrm{E}-02$ & $0.10677 \mathrm{E}-01$ \\
\hline $0.35617 \mathrm{E}-01$ & $0.44322 \mathrm{E}-02$ & 0.29391 & -0.10996 \\
\hline-0.64167 & $0.10677 \mathrm{E}-01$ & -0.10996 & 0.35911 \\
\hline
\end{tabular}


Table 9. $\left(X^{\top} \Lambda^{-1} X\right)^{-1}$ matrices for the T-year $(T=2,5,10,25,50,100,200$, and 500$)$ regional regression equations for Idaho-Continued

\begin{tabular}{|c|c|c|c|}
\hline \multicolumn{4}{|c|}{$\left(X^{\top} \Lambda^{-1} X\right)^{-1}$ matrix } \\
\hline \multicolumn{4}{|c|}{ REGION 2} \\
\hline CONSTANT & DA & $\mathbf{E}$ & $\mathbf{P}$ \\
\hline \multicolumn{4}{|c|}{ 2-year recurrence interval } \\
\hline 0.39901 & $0.98739 \mathrm{E}-03$ & $0.72212 \mathrm{E}-01$ & -0.27258 \\
\hline $0.98739 \mathrm{E}-03$ & $0.13325 \mathrm{E}-02$ & $0.30477 \mathrm{E}-02$ & $-0.32694 \mathrm{E}-02$ \\
\hline $0.72212 \mathrm{E}-01$ & $0.30477 \mathrm{E}-02$ & 0.25340 & -0.14973 \\
\hline-0.27258 & $-0.32694 \mathrm{E}-02$ & -0.14973 & 0.23015 \\
\hline \multicolumn{4}{|c|}{ 5-year recurrence interval } \\
\hline 0.40948 & $0.75032 \mathrm{E}-03$ & $0.70109 \mathrm{E}-01$ & -0.27767 \\
\hline $0.75032 \mathrm{E}-03$ & $0.13652 \mathrm{E}-02$ & $0.32756 \mathrm{E}-02$ & $-0.32653 \mathrm{E}-02$ \\
\hline $0.70109 \mathrm{E}-01$ & $0.32756 \mathrm{E}-02$ & 0.26226 & -0.15266 \\
\hline-0.27767 & $-0.32653 \mathrm{E}-02$ & -0.15266 & 0.23452 \\
\hline \multicolumn{4}{|c|}{ 10-year recurrence interval } \\
\hline 0.43572 & $0.58300 \mathrm{E}-03$ & $0.71219 \mathrm{E}-01$ & -0.29374 \\
\hline $0.58300 \mathrm{E}-03$ & $0.14491 \mathrm{E}-02$ & $0.35727 \mathrm{E}-02$ & $-0.33884 \mathrm{E}-02$ \\
\hline $0.71219 \mathrm{E}-01$ & $0.35727 \mathrm{E}-02$ & 0.28123 & -0.16164 \\
\hline-0.29374 & $-0.33884 \mathrm{E}-02$ & -0.16164 & 0.24816 \\
\hline \multicolumn{4}{|c|}{ 25-year recurrence interval } \\
\hline 0.48030 & $0.37791 \mathrm{E}-03$ & $0.74431 \mathrm{E}-01$ & -0.32172 \\
\hline $0.37791 \mathrm{E}-03$ & $0.15910 \mathrm{E}-02$ & $0.40229 \mathrm{E}-02$ & $-0.36188 \mathrm{E}-02$ \\
\hline $0.74431 \mathrm{E}-01$ & $0.40229 \mathrm{E}-02$ & 0.31249 & -0.17716 \\
\hline-0.32172 & $-0.36188 \mathrm{E}-02$ & -0.17716 & 0.27185 \\
\hline \multicolumn{4}{|c|}{ 50-year recurrence interval } \\
\hline 0.51875 & $0.23295 \mathrm{E}-03$ & $0.77775 \mathrm{E}-01$ & -0.34614 \\
\hline $0.23295 \mathrm{E}-03$ & $0.17127 \mathrm{E}-02$ & $0.43888 \mathrm{E}-02$ & $-0.38254 \mathrm{E}-02$ \\
\hline $0.77775 \mathrm{E}-01$ & $0.43888 \mathrm{E}-02$ & 0.33895 & -0.19062 \\
\hline-0.34614 & $-0.38254 \mathrm{E}-02$ & -0.19062 & 0.29249 \\
\hline \multicolumn{4}{|c|}{ 100-year recurrence interval } \\
\hline 0.56026 & $0.95155 \mathrm{E}-04$ & $0.81735 \mathrm{E}-01$ & -0.37268 \\
\hline $0.95155 \mathrm{E}-04$ & $0.18437 \mathrm{E}-02$ & $0.47711 \mathrm{E}-02$ & $-0.40529 \mathrm{E}-02$ \\
\hline $0.81735 \mathrm{E}-01$ & $0.47711 \mathrm{E}-02$ & 0.36719 & -0.20520 \\
\hline-0.37268 & $-0.40529 \mathrm{E}-02$ & -0.20520 & 0.31490 \\
\hline \multicolumn{4}{|c|}{ 200-year recurrence interval } \\
\hline 0.60440 & $-0.36634 \mathrm{E}-04$ & $0.86222 \mathrm{E}-01$ & -0.40104 \\
\hline$-0.36634 \mathrm{E}-04$ & $0.19825 \mathrm{E}-02$ & $0.51679 \mathrm{E}-02$ & $-0.42981 \mathrm{E}-02$ \\
\hline $0.86222 \mathrm{E}-01$ & $0.51679 \mathrm{E}-02$ & 0.39694 & -0.22073 \\
\hline-0.40104 & $-0.42981 \mathrm{E}-02$ & -0.22073 & 0.33883 \\
\hline \multicolumn{4}{|c|}{ 500-year recurrence interval } \\
\hline 0.66637 & $-0.20300 \mathrm{E}-03$ & $0.92873 \mathrm{E}-01$ & -0.44102 \\
\hline$-0.20300 \mathrm{E}-03$ & $0.21769 \mathrm{E}-02$ & $0.57136 \mathrm{E}-02$ & $-0.46470 \mathrm{E}-02$ \\
\hline $0.92873 \mathrm{E}-01$ & $0.57136 \mathrm{E}-02$ & 0.43836 & -0.24258 \\
\hline-0.44102 & $-0.46470 \mathrm{E}-02$ & -0.24258 & 0.37254 \\
\hline
\end{tabular}


Table 9. $\left(X^{\top} \Lambda^{-1} X\right)^{-1}$ matrices for the T-year $(T=2,5,10,25,50,100,200$, and 500$)$ regional regression equations for Idaho-Continued

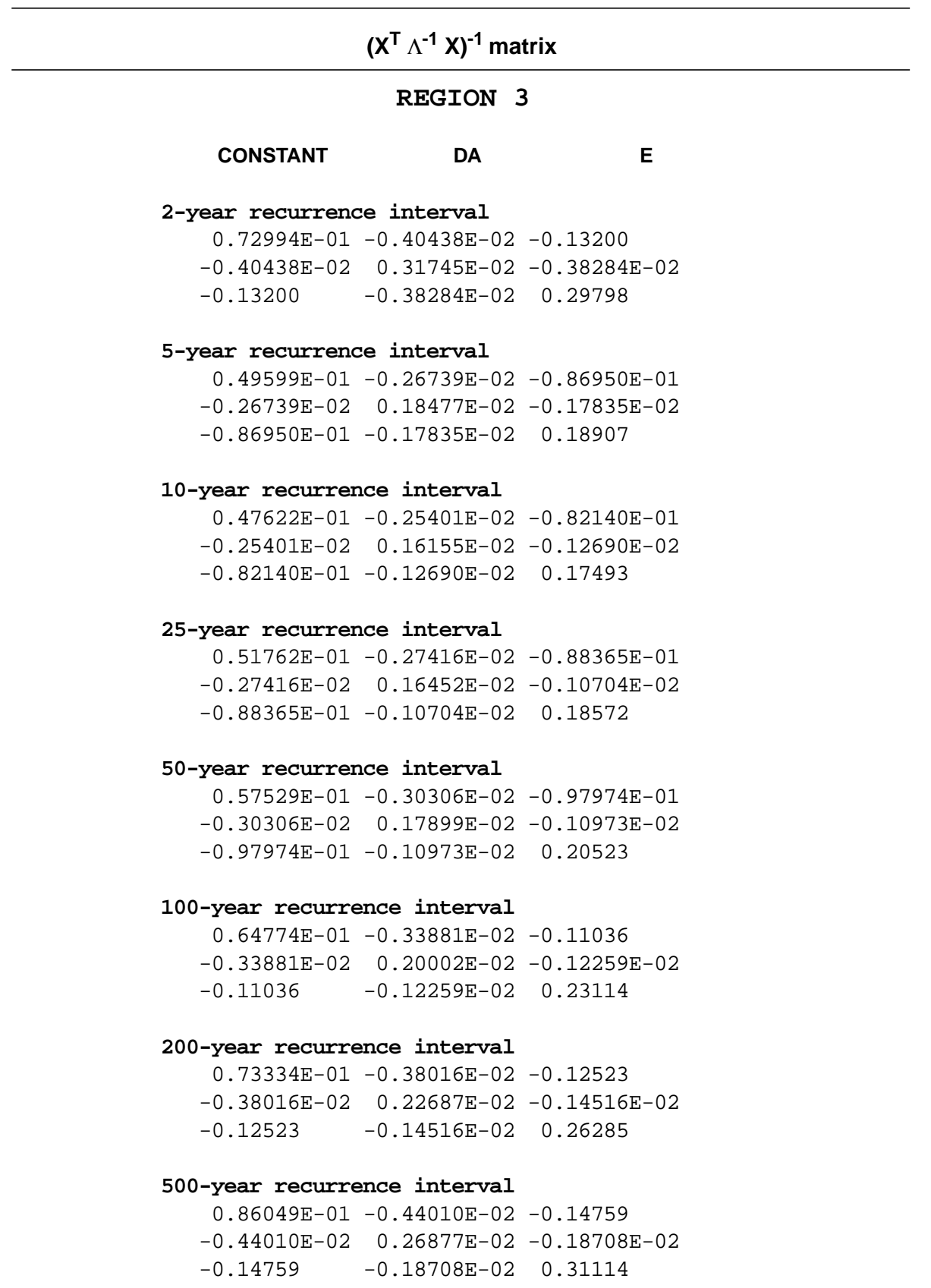


Table 9. $\left(X^{\top} \Lambda^{-1} X\right)^{-1}$ matrices for the T-year $(T=2,5,10,25,50,100,200$, and 500$)$ regional regression equations for Idaho-Continued

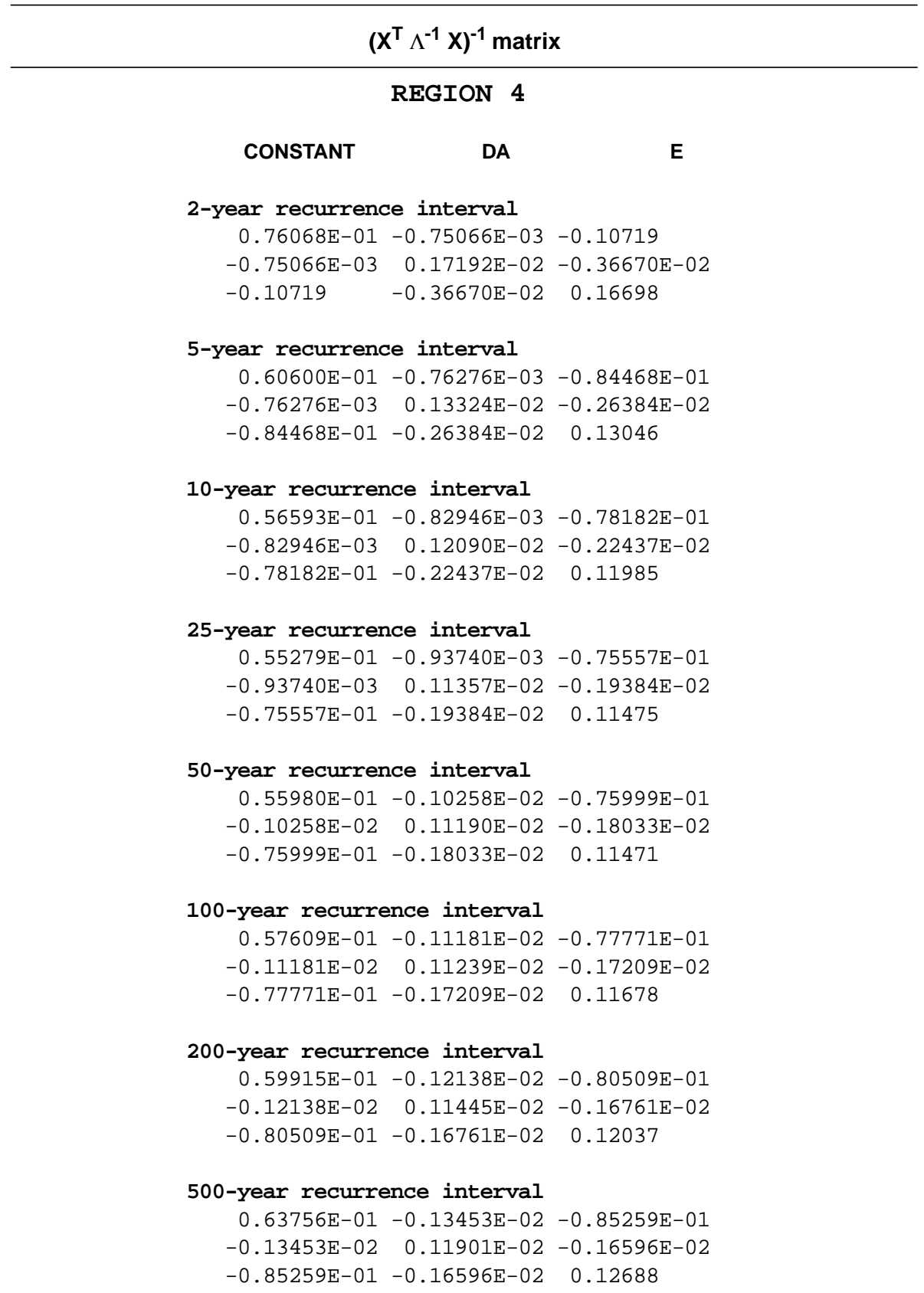


Table 9. $\left(X^{\top} \Lambda^{-1} X\right)^{-1}$ matrices for the T-year $(T=2,5,10,25,50,100,200$, and 500$)$ regional regression equations for Idaho-Continued

\begin{tabular}{|c|c|c|c|}
\hline \multicolumn{4}{|c|}{$\left(X^{\top} \Lambda^{-1} X\right)^{-1}$ matrix } \\
\hline \multicolumn{4}{|c|}{ REGION 5} \\
\hline CONSTANT & DA & $\mathbf{P}$ & NF30 \\
\hline \multicolumn{4}{|c|}{ 2-year recurrence interval } \\
\hline 0.27767 & $-0.62717 \mathrm{E}-02$ & -0.15755 & $-0.21191 \mathrm{E}-01$ \\
\hline$-0.62717 \mathrm{E}-02$ & $0.15842 \mathrm{E}-02$ & $0.33900 \mathrm{E}-02$ & $-0.17302 \mathrm{E}-02$ \\
\hline-0.15755 & $0.33900 \mathrm{E}-02$ & $0.98903 E-01$ & $0.12712 \mathrm{E}-02$ \\
\hline$-0.21191 \mathrm{E}-01$ & $-0.17302 \mathrm{E}-02$ & $0.12712 \mathrm{E}-02$ & $0.18410 \mathrm{E}-01$ \\
\hline \multicolumn{4}{|c|}{ 5-year recurrence interval } \\
\hline 0.26636 & $-0.65343 E-02$ & -0.15078 & $-0.19510 \mathrm{E}-01$ \\
\hline$-0.65343 \mathrm{E}-02$ & $0.15652 \mathrm{E}-02$ & $0.35123 \mathrm{E}-02$ & $-0.16736 \mathrm{E}-02$ \\
\hline-0.15078 & $0.35123 \mathrm{E}-02$ & $0.94362 \mathrm{E}-01$ & $0.94276 \mathrm{E}-03$ \\
\hline$-0.19510 \mathrm{E}-01$ & $-0.16736 \mathrm{E}-02$ & $0.94276 \mathrm{E}-03$ & $0.17377 \mathrm{E}-01$ \\
\hline \multicolumn{4}{|c|}{ 10-year recurrence interval } \\
\hline 0.27539 & $-0.72395 E-02$ & -0.15568 & $-0.19203 \mathrm{E}-01$ \\
\hline$-0.72395 \mathrm{E}-02$ & $0.16639 \mathrm{E}-02$ & $0.38862 \mathrm{E}-02$ & $-0.17632 \mathrm{E}-02$ \\
\hline-0.15568 & $0.38862 \mathrm{E}-02$ & $0.97206 \mathrm{E}-01$ & $0.60777 \mathrm{E}-03$ \\
\hline$-0.19203 \mathrm{E}-01$ & $-0.17632 \mathrm{E}-02$ & $0.60777 \mathrm{E}-03$ & $0.17717 \mathrm{E}-01$ \\
\hline \multicolumn{4}{|c|}{ 25-year recurrence interval } \\
\hline 0.29496 & $-0.83118 \mathrm{E}-02$ & -0.16653 & $-0.19363 \mathrm{E}-01$ \\
\hline$-0.83118 \mathrm{E}-02$ & $0.18324 \mathrm{E}-02$ & $0.44586 \mathrm{E}-02$ & $-0.19283 \mathrm{E}-02$ \\
\hline-0.16653 & $0.44586 \mathrm{E}-02$ & 0.10373 & $0.18438 \mathrm{E}-03$ \\
\hline$-0.19363 \mathrm{E}-01$ & $-0.19283 \mathrm{E}-02$ & $0.18438 \mathrm{E}-03$ & $0.18681 \mathrm{E}-01$ \\
\hline \multicolumn{4}{|c|}{ 50-year recurrence interval } \\
\hline 0.31294 & $-0.91632 \mathrm{E}-02$ & -0.17655 & $-0.19762 \mathrm{E}-01$ \\
\hline$-0.91632 \mathrm{E}-02$ & $0.19733 \mathrm{E}-02$ & $0.49139 \mathrm{E}-02$ & $-0.20698 \mathrm{E}-02$ \\
\hline-0.17655 & $0.49139 \mathrm{E}-02$ & 0.10982 & $-0.11140 \mathrm{E}-03$ \\
\hline$-0.19762 \mathrm{E}-01$ & $-0.20698 \mathrm{E}-02$ & $-0.11140 \mathrm{E}-03$ & $0.19632 \mathrm{E}-01$ \\
\hline \multicolumn{4}{|c|}{ 100-year recurrence interval } \\
\hline 0.33276 & $-0.10035 \mathrm{E}-01$ & -0.18763 & $-0.20337 \mathrm{E}-01$ \\
\hline$-0.10035 \mathrm{E}-01$ & $0.21217 \mathrm{E}-02$ & $0.53802 \mathrm{E}-02$ & $-0.22203 E-02$ \\
\hline-0.18763 & $0.53802 \mathrm{E}-02$ & 0.11659 & $-0.38839 \mathrm{E}-03$ \\
\hline$-0.20337 \mathrm{E}-01$ & $-0.22203 E-02$ & $-0.38839 \mathrm{E}-03$ & $0.20716 \mathrm{E}-01$ \\
\hline \multicolumn{4}{|c|}{ 200-year recurrence interval } \\
\hline 0.35403 & $-0.10924 \mathrm{E}-01$ & -0.19954 & $-0.21051 \mathrm{E}-01$ \\
\hline$-0.10924 \mathrm{E}-01$ & $0.22763 \mathrm{E}-02$ & $0.58558 \mathrm{E}-02$ & $-0.23778 \mathrm{E}-02$ \\
\hline-0.19954 & $0.58558 \mathrm{E}-02$ & 0.12389 & $-0.64991 \mathrm{E}-03$ \\
\hline$-0.21051 \mathrm{E}-01$ & $-0.23778 \mathrm{E}-02$ & $-0.64991 \mathrm{E}-03$ & $0.21904 \mathrm{E}-01$ \\
\hline \multicolumn{4}{|c|}{ 500-year recurrence interval } \\
\hline 0.38398 & $-0.12124 \mathrm{E}-01$ & -0.21633 & $-0.22174 \mathrm{E}-01$ \\
\hline$-0.12124 \mathrm{E}-01$ & $0.24889 \mathrm{E}-02$ & $0.64978 \mathrm{E}-02$ & $-0.25949 \mathrm{E}-02$ \\
\hline-0.21633 & $0.64978 \mathrm{E}-02$ & 0.13421 & $-0.97656 \mathrm{E}-03$ \\
\hline$-0.22174 \mathrm{E}-01$ & $-0.25949 \mathrm{E}-02$ & $-0.97656 \mathrm{E}-03$ & $0.23608 \mathrm{E}-01$ \\
\hline
\end{tabular}


Table 9. $\left(X^{\top} \Lambda^{-1} X\right)^{-1}$ matrices for the T-year $(T=2,5,10,25,50,100,200$, and 500$)$ regional regression equations for Idaho-Continued

\begin{tabular}{|c|c|c|}
\hline \multicolumn{3}{|c|}{$\left(X^{\top} \Lambda^{-1} X\right)^{-1}$ matrix } \\
\hline \multicolumn{3}{|c|}{ REGION 6} \\
\hline CONSTANT & DA & $\mathbf{P}$ \\
\hline \multicolumn{3}{|c|}{ 2-year recurrence interval } \\
\hline 0.73182 & $-0.19589 \mathrm{E}-01$ & -0.50715 \\
\hline$-0.19589 \mathrm{E}-01$ & $0.32568 \mathrm{E}-02$ & $0.93413 \mathrm{E}-02$ \\
\hline-0.50715 & $0.93413 \mathrm{E}-02$ & 0.35932 \\
\hline \multicolumn{3}{|c|}{ 5-year recurrence interval } \\
\hline 0.64178 & $-0.17889 \mathrm{E}-01$ & -0.44309 \\
\hline$-0.17889 \mathrm{E}-01$ & $0.28998 \mathrm{E}-02$ & $0.85868 \mathrm{E}-02$ \\
\hline-0.44309 & $0.85868 \mathrm{E}-02$ & 0.31296 \\
\hline \multicolumn{3}{|c|}{ 10-year recurrence interval } \\
\hline 0.64897 & $-0.18653 E-01$ & -0.44665 \\
\hline$-0.18653 \mathrm{E}-01$ & $0.29679 \mathrm{E}-02$ & $0.89884 \mathrm{E}-02$ \\
\hline-0.44665 & $0.89884 \mathrm{E}-02$ & 0.31468 \\
\hline \multicolumn{3}{|c|}{ 25-year recurrence interval } \\
\hline 0.68723 & $-0.20406 \mathrm{E}-01$ & -0.47131 \\
\hline$-0.20406 \mathrm{E}-01$ & $0.31852 \mathrm{E}-02$ & $0.98667 \mathrm{E}-02$ \\
\hline-0.47131 & $0.98667 \mathrm{E}-02$ & 0.33111 \\
\hline \multicolumn{3}{|c|}{ 50-year recurrence interval } \\
\hline 0.72572 & $-0.21964 \mathrm{E}-01$ & -0.49663 \\
\hline$-0.21964 \mathrm{E}-01$ & $0.33910 \mathrm{E}-02$ & $0.10638 \mathrm{E}-01$ \\
\hline-0.49663 & $0.10638 \mathrm{E}-01$ & 0.34829 \\
\hline \multicolumn{3}{|c|}{ 100-year recurrence interval } \\
\hline 0.76837 & $-0.23615 E-01$ & -0.52486 \\
\hline$-0.23615 \mathrm{E}-01$ & $0.36143 \mathrm{E}-02$ & $0.11450 \mathrm{E}-01$ \\
\hline-0.52486 & $0.11450 \mathrm{E}-01$ & 0.36756 \\
\hline \multicolumn{3}{|c|}{ 200-year recurrence interval } \\
\hline 0.81351 & $-0.25317 \mathrm{E}-01$ & -0.55485 \\
\hline$-0.25317 \mathrm{E}-01$ & $0.38479 \mathrm{E}-02$ & $0.12286 \mathrm{E}-01$ \\
\hline-0.55485 & $0.12286 \mathrm{E}-01$ & 0.38810 \\
\hline \multicolumn{3}{|c|}{ 500-year recurrence interval } \\
\hline 0.87556 & $-0.27612 \mathrm{E}-01$ & -0.59621 \\
\hline$-0.27612 \mathrm{E}-01$ & $0.41662 \mathrm{E}-02$ & $0.13411 \mathrm{E}-01$ \\
\hline-0.59621 & $0.13411 \mathrm{E}-01$ & 0.41650 \\
\hline
\end{tabular}


Table 9. $\left(X^{\top} \Lambda^{-1} X\right)^{-1}$ matrices for the $T$-year $(T=2,5,10,25,50,100,200$, and 500$)$ regional regression equations for Idaho-Continued

\begin{tabular}{|c|c|c|}
\hline \multicolumn{3}{|c|}{$\left(X^{\top} \Lambda^{-1} X\right)^{-1}$ matrix } \\
\hline \multicolumn{3}{|c|}{ REGION $7 a$} \\
\hline CONSTANT & DA & $\mathbf{E}$ \\
\hline \multicolumn{3}{|c|}{ 2-year recurrence interval } \\
\hline 0.27535 & $-0.10043 \mathrm{E}-01$ & -0.32931 \\
\hline$-0.10043 E-01$ & $0.29644 \mathrm{E}-02$ & $0.69738 \mathrm{E}-02$ \\
\hline-0.32931 & $0.69738 \mathrm{E}-02$ & 0.40923 \\
\hline \multicolumn{3}{|c|}{ 5-year recurrence interval } \\
\hline 0.23543 & $-0.88447 \mathrm{E}-02$ & -0.27938 \\
\hline$-0.88447 \mathrm{E}-02$ & $0.22933 \mathrm{E}-02$ & $0.66030 \mathrm{E}-02$ \\
\hline-0.27938 & $0.66030 \mathrm{E}-02$ & 0.34388 \\
\hline \multicolumn{3}{|c|}{ 10-year recurrence interval } \\
\hline 0.24212 & $-0.92360 \mathrm{E}-02$ & -0.28606 \\
\hline$-0.92360 \mathrm{E}-02$ & $0.21875 \mathrm{E}-02$ & $0.71983 \mathrm{E}-02$ \\
\hline-0.28606 & $0.71983 \mathrm{E}-02$ & 0.35006 \\
\hline \multicolumn{3}{|c|}{ 25-year recurrence interval } \\
\hline 0.26803 & $-0.10339 \mathrm{E}-01$ & -0.31562 \\
\hline$-0.10339 \mathrm{E}-01$ & $0.22544 \mathrm{E}-02$ & $0.83448 \mathrm{E}-02$ \\
\hline-0.31562 & $0.83448 \mathrm{E}-02$ & 0.38440 \\
\hline \multicolumn{3}{|c|}{ 50-year recurrence interval } \\
\hline 0.29504 & $-0.11429 \mathrm{E}-01$ & -0.34698 \\
\hline$-0.11429 \mathrm{E}-01$ & $0.23961 \mathrm{E}-02$ & $0.93703 \mathrm{E}-02$ \\
\hline-0.34698 & $0.93703 \mathrm{E}-02$ & 0.42175 \\
\hline \multicolumn{3}{|c|}{ 100-year recurrence interval } \\
\hline 0.32653 & $-0.12680 \mathrm{E}-01$ & -0.38378 \\
\hline$-0.12680 \mathrm{E}-01$ & $0.25920 \mathrm{E}-02$ & $0.10499 \mathrm{E}-01$ \\
\hline-0.38378 & $0.10499 \mathrm{E}-01$ & 0.46596 \\
\hline \multicolumn{3}{|c|}{ 200-year recurrence interval } \\
\hline 0.36169 & $-0.14066 \mathrm{E}-01$ & -0.42502 \\
\hline$-0.14066 \mathrm{E}-01$ & $0.28316 \mathrm{E}-02$ & $0.11719 \mathrm{E}-01$ \\
\hline-0.42502 & $0.11719 \mathrm{E}-01$ & 0.51577 \\
\hline \multicolumn{3}{|c|}{ 500-year recurrence interval } \\
\hline 0.41302 & $-0.16081 \mathrm{E}-01$ & -0.48542 \\
\hline$-0.16081 \mathrm{E}-01$ & $0.32057 \mathrm{E}-02$ & $0.13456 \mathrm{E}-01$ \\
\hline-0.48542 & $0.13456 \mathrm{E}-01$ & 0.58902 \\
\hline
\end{tabular}


Table 9. $\left(X^{\top} \Lambda^{-1} X\right)^{-1}$ matrices for the T-year $(T=2,5,10,25,50,100,200$, and 500$)$ regional regression equations for Idaho-Continued

$$
\left(\mathbf{X}^{\mathrm{T}} \Lambda^{-1} \mathrm{X}\right)^{-1} \text { matrix }
$$

REGION $7 b$

$\begin{array}{ll}\text { CONSTANT DA } & \text { D }\end{array}$

2-year recurrence interval

$0.52959 \mathrm{E}-01-0.27639 \mathrm{E}-01$

$-0.27639 \mathrm{E}-01 \quad 0.17103 \mathrm{E}-01$

5-year recurrence interval

$0.35447 \mathrm{E}-01-0.18388 \mathrm{E}-01$

$-0.18388 \mathrm{E}-01 \quad 0.11360 \mathrm{E}-01$

10-year recurrence interval

$0.28742 \mathrm{E}-01-0.14817 \mathrm{E}-01$

$-0.14817 \mathrm{E}-01 \quad 0.91404 \mathrm{E}-02$

25-year recurrence interval

$0.24078 \mathrm{E}-01-0.12308 \mathrm{E}-01$

$-0.12308 \mathrm{E}-01 \quad 0.75821 \mathrm{E}-02$

50-year recurrence interval

$0.22709 \mathrm{E}-01-0.11549 \mathrm{E}-01$

$-0.11549 \mathrm{E}-01 \quad 0.71136 \mathrm{E}-02$

100-year recurrence interval $0.22745 \mathrm{E}-01-0.11530 \mathrm{E}-01$

$-0.11530 \mathrm{E}-01 \quad 0.71060 \mathrm{E}-02$

200-year recurrence interval $0.23947 \mathrm{E}-01-0.12122 \mathrm{E}-01$

$-0.12122 \mathrm{E}-01 \quad 0.74783 \mathrm{E}-02$

500-year recurrence interval

$0.27094 \mathrm{E}-01-0.13718 \mathrm{E}-01$

$-0.13718 \mathrm{E}-01 \quad 0.84751 \mathrm{E}-02$ 
Table 9. $\left(X^{\top} \Lambda^{-1} X\right)^{-1}$ matrices for the T-year $(T=2,5,10,25,50,100,200$, and 500$)$ regional regression equations for Idaho-Continued

\begin{tabular}{|c|c|c|c|}
\hline \multicolumn{4}{|c|}{$\left(X^{\top} \Lambda^{-1} X\right)^{-1}$ matrix } \\
\hline \multicolumn{4}{|c|}{ REGION 8} \\
\hline CONSTANT & DA & $\mathbf{P}$ & S30 \\
\hline \multicolumn{4}{|c|}{ 2-year recurrence interval } \\
\hline 0.13509 & $-0.10754 \mathrm{E}-01$ & -0.17622 & $0.87079 \mathrm{E}-01$ \\
\hline$-0.10754 \mathrm{E}-01$ & $0.29289 \mathrm{E}-02$ & $0.75498 \mathrm{E}-02$ & $-0.32850 \mathrm{E}-02$ \\
\hline-0.17622 & $0.75498 \mathrm{E}-02$ & 0.30082 & -0.17123 \\
\hline $0.87079 \mathrm{E}-01$ & $-0.32850 \mathrm{E}-02$ & -0.17123 & 0.10528 \\
\hline \multicolumn{4}{|c|}{ 5-year recurrence interval } \\
\hline 0.11982 & $-0.95381 E-02$ & -0.15664 & $0.77537 \mathrm{E}-01$ \\
\hline$-0.95381 \mathrm{E}-02$ & $0.26072 \mathrm{E}-02$ & $0.66765 \mathrm{E}-02$ & $-0.29116 \mathrm{E}-02$ \\
\hline-0.15664 & $0.66765 \mathrm{E}-02$ & 0.26855 & -0.15317 \\
\hline $0.77537 \mathrm{E}-01$ & $-0.29116 \mathrm{E}-02$ & -0.15317 & $0.94356 \mathrm{E}-01$ \\
\hline \multicolumn{4}{|c|}{ 10-year recurrence interval } \\
\hline 0.11788 & $-0.94019 \mathrm{E}-02$ & -0.15429 & $0.76478 \mathrm{E}-01$ \\
\hline$-0.94019 \mathrm{E}-02$ & $0.25782 \mathrm{E}-02$ & $0.65545 \mathrm{E}-02$ & $-0.28648 \mathrm{E}-02$ \\
\hline-0.15429 & $0.65545 \mathrm{E}-02$ & 0.26551 & -0.15173 \\
\hline $0.76478 \mathrm{E}-01$ & $-0.28648 \mathrm{E}-02$ & -0.15173 & $0.93636 \mathrm{E}-01$ \\
\hline \multicolumn{4}{|c|}{ 25-year recurrence interval } \\
\hline 0.11957 & $-0.95651 \mathrm{E}-02$ & -0.15673 & $0.77832 \mathrm{E}-01$ \\
\hline$-0.95651 \mathrm{E}-02$ & $0.26337 \mathrm{E}-02$ & $0.66320 \mathrm{E}-02$ & $-0.29078 E-02$ \\
\hline-0.15673 & $0.66320 \mathrm{E}-02$ & 0.27107 & -0.15530 \\
\hline $0.77832 \mathrm{E}-01$ & $-0.29078 \mathrm{E}-02$ & -0.15530 & $0.96081 E-01$ \\
\hline \multicolumn{4}{|c|}{ 50-year recurrence interval } \\
\hline 0.12248 & $-0.98191 \mathrm{E}-02$ & -0.16072 & $0.79924 \mathrm{E}-01$ \\
\hline$-0.98191 \mathrm{E}-02$ & $0.27113 \mathrm{E}-02$ & $0.67827 \mathrm{E}-02$ & $-0.29807 E-02$ \\
\hline-0.16072 & $0.67827 \mathrm{E}-02$ & 0.27900 & -0.16015 \\
\hline $0.79924 \mathrm{E}-01$ & $-0.29807 \mathrm{E}-02$ & -0.16015 & $0.99257 \mathrm{E}-01$ \\
\hline \multicolumn{4}{|c|}{ 100-year recurrence interval } \\
\hline 0.12621 & $-0.10138 \mathrm{E}-01$ & -0.16580 & $0.82561 \mathrm{E}-01$ \\
\hline$-0.10138 \mathrm{E}-01$ & $0.28066 \mathrm{E}-02$ & $0.69799 \mathrm{E}-02$ & $-0.30741 E-02$ \\
\hline-0.16580 & $0.69799 \mathrm{E}-02$ & 0.28883 & -0.16609 \\
\hline $0.82561 \mathrm{E}-01$ & $-0.30741 \mathrm{E}-02$ & -0.16609 & 0.10311 \\
\hline \multicolumn{4}{|c|}{ 200-year recurrence interval } \\
\hline 0.13049 & $-0.10500 \mathrm{E}-01$ & -0.17161 & $0.85568 \mathrm{E}-01$ \\
\hline$-0.10500 \mathrm{E}-01$ & $0.29136 \mathrm{E}-02$ & $0.72086 \mathrm{E}-02$ & $-0.31814 \mathrm{E}-02$ \\
\hline-0.17161 & $0.72086 \mathrm{E}-02$ & 0.29995 & -0.17277 \\
\hline $0.85568 \mathrm{E}-01$ & $-0.31814 \mathrm{E}-02$ & -0.17277 & 0.10744 \\
\hline \multicolumn{4}{|c|}{ 500-year recurrence interval } \\
\hline 0.13677 & $-0.11027 \mathrm{E}-01$ & -0.18014 & $0.89964 \mathrm{E}-01$ \\
\hline$-0.11027 \mathrm{E}-01$ & $0.30682 \mathrm{E}-02$ & $0.75464 \mathrm{E}-02$ & $-0.33391 E-02$ \\
\hline-0.18014 & $0.75464 \mathrm{E}-02$ & 0.31613 & -0.18247 \\
\hline $0.89964 \mathrm{E}-01$ & $-0.33391 \mathrm{E}-02$ & -0.18247 & 0.11368 \\
\hline
\end{tabular}

